\title{
Resources for Research on Analogy: A Multi-disciplinary Guide
}

\section{Marcello Guarini ${ }^{\mathbb{1}}$}

Department of Philosophy

University of Windsor

Windsor, ON

Canada

mguarini@uwindsor.ca

\section{AMY BUTCHART}

Department of Philosophy

Guelph University

Gulph, ON

Canada

abutchar@uoguelph.ca

\section{Paul Simard Smith}

Department of Philosophy

University of Waterloo

Waterloo, ON

Canada

paul.simardsmith@gmail.com

\section{ANDREI MOLDOVAN}

Faculty of Philosophy

Department of Logic, History and Philosophy of Science

University of Barcelona

Barcelona, Spain

mandreius@yahoo.com

* The first author wishes to thank the Social Sciences and Humanities Research Council of Canada for financial support over the four years during which this project was completed. 


\begin{abstract}
Work on analogy has been done from a number of disciplinary perspectives throughout the history of Western thought. This work is a multidisciplinary guide to theorizing about analogy. It contains 1,406 references, primarily to journal articles and monographs, and primarily to English language material. Classical through to contemporary sources are included. The work is classified into eight different sections (with a number of subsections). A brief introduction to each section is provided. Keywords and key expressions of importance to research on analogy are discussed in the introductory material. Electronic resources for conducting research on analogy are listed as well.
\end{abstract}

Résumé: Diverses perspectives disciplinaires à travers l'histoire de la pensée occidentale ont contribué à la recherche sur les analogies. Cet article est un guide multidisciplinaire sur la théorie de l'analogie. Il y contient 1,406 références tirées principalement des articles et de livres anglophones. On y inclut des sources classiques et contemporaines, ainsi que des sources électroniques. Huit sections classifient ce matériel. Une brève introduction, dans laquelle on identifie des mots clefs importants pour faciliter la recherche, précède chaque section.

Keywords: Aesthetics, argument scheme, art, axiomatic approach, bijection, case based reasoning (CBR), case law, casuistry, cognition, common law, engineering, ethics, example, exemplar, frame, homology, homomorphism, homoplasty, isomorphism, language, law, literature, logic, logical reconstruction, mathematics, mental model, metaphor, mind, model, model based reasoning, legal particularism, memory, mental space mapping (or conceptual blending), moral particularism, paradigm, pedagogy, precedent, problem solving, prototype, qiyas, ratio dicindi, reasoning, religion, retrieval, sciences (natural and social), similarity, simulation theory, simulationism, scheme, stare decicis, structure mapping, theology, visual analogy. 


\section{Contents}

Introduction

Scope and Limits

Division of Work

Other Key Expressions

Sections and Subsections (Descriptions)

1. Arts or Aesthetics

2. Normative Treatments of Action

2.1 Law

2.2 Ethics or Action

3. Religion or Theology: Language, Logic, or Metaphysics

4. Sciences or Engineering

5. Mathematics

6. Mind, Consciousness, or Cognition

7. General or Wide Ranging

7.1 Child Development, Learning, Pedagogy, and Problem Solving

7.2 Language or Metaphysics

7.3 Visual Analogy

7.4 Animal

7.5 Memory or Retrieval

7.6 Logic

7.7 Various

8. Other

Further Resources

References (Lists of References)

1. Arts or Aesthetics

2. Normative Treatments of Action

2.1 Law

2.2 Ethics or Action

3. Religion or Theology: Language, Logic, or Metaphysics

4. Sciences or Engineering

5. Mathematics

6. Mind, Consciousness, or Cognition

7. General or Wide Ranging

7.1 Child Development, Learning, Pedagogy, and Problem Solving

7.2 Language or Metaphysics

7.3 Visual Analogy

7.4 Animal

7.5 Memory or Retrieval

7.6 Logic

7.7 Various

8. Other 


\section{Introduction}

Many different things have been referred to as analogies or as analogous, and analogy has been studied from a number of disciplinary perspectives. This work brings together research from different fields to provide a useful reference tool both to those starting out in their research on analogy and to experts who may want a resource guide to inform future work. The research referenced includes, but is not limited to, work from argumentation theory, artificial intelligence (AI), cognitive science, linguistics, mathematics, natural sciences, philosophy, psychology, and (other) social sciences.

This collection of work strives to be inclusive not only in the sense of listing work from different disciplines, but also with respect to different understandings of analogy. While much of the work is contemporary, classical and medieval sources are included as well. This introduces terminological issues that affect the substantive scope of the project. For example, the classical Greek term for analogy (analogia or

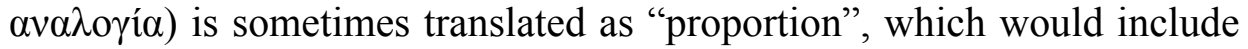
ratios (2 is to 4 as 4 is to 8 ). More recent uses of "analogy" do not always capture some of its more classical uses. It is worth keeping in mind this diversity of uses since some work referenced herein may contain few if any uses of "analogy" but perhaps many references to "proportion" (as in some of Aristotle's texts).

A mere reference to or use of analogy is insufficient for a work to be included in this collection. The work we have included attempts to theorize about or otherwise elucidate one or more of the uses of analogy. The next section outlines the scope of the work included.

\section{Scope and Limits}

This work does not attempt an exhaustive cataloguing of all work done on analogy. Perhaps the most obvious limit is that it primarily catalogues work in English. Where this English language work cites foreign language work, that foreign language work on analogy has been included. Similarly, the bulk of the work referenced herein is from Western academic traditions; where non-Western work has been cited by Western work, it has been included. With respect to the form of publication, we are primarily concerned to catalogue journal articles and monographs. Some high caliber encyclopedia entries (for example, entries from MIT CogNet or the Stanford Encyclopedia of Philosophy) are also included. Textbooks and papers in conference proceedings are not generally included, though there are exceptions. The number of introductory textbooks in ethics, law, logic, reasoning skills, and the like are legion, and many of them mention analogy. The guiding concern throoughout this work has been to make this collection of resources as useful as possible to researchers looking for advanced theorizing about 
analogy. If a textbook is cited and engaged in journal articles or monographs (i.e. the theoretical literature) on analogy, then it is included. With respect to papers in conference proceedings, they are included either if they are cited in the theoretical literature or if they are part of a major theorist's body of work on analogy. Paper versions of conference proceedings for conferences devoted entirely to analogy are also included. A list of research tools is included below (Further Resources) for those who may wish to pursue a more exhaustive study of work devoted or related to analogy. Some of these resources can be especially useful in locating material in conference proceedings.

\section{Division of Work}

There are different ways to divide up a collection of references. Each will have its own advantages and disadvantages. The principal decision we faced was whether to divide references by the subject matter of the analogy or the disciplinary or methodological approach taken to the subject. Our guiding concern throughout was to make this work as useful as possible to researchers, and this led us to group references by subject matter. If we had grouped work by disciplinary approach, then the section on philosophical approaches would include philosophical reflections on analogy in ethics, law, natural science, mathematics, religion, social science, and other areas as well. Something similar would happen if we grouped all work in AI in one section. There is an advantage to this approach: those interested, say, only in work in AI on analogy would could go to one section and get exactly what is desired. There are also disadvantages. First, much work on analogy tends to be domain specific. It is work on analogy in Law, or analogy in one or more of the Natural Sciences, or in Mathematics, and so on. Dividing work by discipline or methodological approach would make it much more difficult to find the work on analogy focused on a specific subject matter. Second, even when work on analogy is clearly making use of methods from a specific discipline, it is not unusual for that work to cite research from other disciplines. For example, there is no shortage of work in AI or Law that cites work in Philosophy. Given that much work is subject or domain specific, and given that researchers are often interested in making use of work outside their own discipline when theorizing about analogy in a particular domain, dividing work up by the subject matter of the analogy is looking increasingly well motivated. Third, there are times when it is very difficult to be clear on what exactly the disciplinary approach is. There is overlap between Cognitive Science and AI, and Cognitive Science and Linguistics, and Cognitive Science and Psychology. Dividing work up by the subject matter of the analogy largely side-steps these issues. For example, if the subject matter of the anaogy is mind or mental states, then the work is placed in the Mind, Consciousness, or Cognition section (regarless of whether the work is 
done by an AI researcher, a cognitive scientist, a philosopher, or a psychologist).

Of course, focusing on the subject matter of the analogy has its own problems. It turns out that much work on analogy is general or wide ranging in nature. In other words, it is not aimed at a specific subject or domain (Law, Mathematics, or whatever), or it is specifically aimed at two or more domains. For this reason, there is a section entitled General or Wide Ranging, and it contains several subsections. While this may seem a bit of an awkward accommodation, we prefer it over a disciplinary or methodological division of work. The reason is that even within the individual subsections of the General or Wide Ranging category, work from different disciplines using different methods can be found. The preceding not withstanding, there are still difficulties with an approach focused on subject matter. Sometimes, it is not always clear what counts as a subject matter. Is visual reasoning a distinct subject matter? Should work on visual analogy be seen as a distinct subject matter and collected under one heading? It is a tough call. Some work on visual analogy fits neatly in the Science or Engineering section since it deals with a scientific subject, so we placed it in that section; some work on visual analogy is more general, and this is why we collected such work in one of the subsections of the General or Wide Ranging category. That said, we could see how there could be differences of opinion, and we recognize that there would be some utility in collecting all work on visual analogy in one section (even if some of it is devoted specifically to natural science). Each of the sections and subsections below contains a brief summary of the contents of that section. In cases where there is not general agreement on what constitutes a domain or subject matter, we have endeavored to make it clear how work has been classified.

\section{Other Key Expressions}

Given the number of approaches to the study of analogy and the variety of phenomena referred to as analogies or analogous, it is not surprising that there is a variety of key terms and expressions associated with the study of analogy. Some of these terms are summarized here, and they will be indicated in bold print in what follows for easy identification.

Argument scheme, axiomatic approach, bijection, case based reasoning (CBR), case law, casuistry, common law, example, exemplar, frame, homology, homomorphism, homoplasty, isomorphism, mental model, metaphor, model, model based reasoning, legal particularism, mental space mapping (or conceptual blending), moral particularism, paradigm, precedent, prototype, qiyas, ratio dicindi, similarity, simulation theory, simulationism, scheme, stare decicis, structure mapping, visual analogy. 


\section{Sections and Subsections}

The first three sections below list work where the subject of analogy includes topics of concern often falling under the heading humanities. This is not to say that the work is done only by those in the humanities. Far from it. Much work on analogy in law has been done by researchers in AI. Sections four and five deal with analogy in the sciences (including engineering) and mathematics. Again, contributions to analogy in these domains need not come from its practitioners. Philosophers of science and mathematics have contributed to understanding analogy in these areas. For reasons explained in section six, analogies taking as their subject mind or cognition are collected under one heading. Work on analogy that is of a more general or wide ranging nature is collected in section seven, and work that does not fit into any of the preceding categories is collected in section eight.

1. Arts or Aesthetics

2. Normative Treatments of Action

2.1 Law

2.2 Ethics or Action

3. Religion or Theology: Language, Logic, or Metaphysics

4. Sciences or Engineering

5. Mathematics

6. Mind, Consciousness, or Cognition

7. General or Wide Ranging

7.1 Child Development, Learning, Pedagogy, and Problem Solving

7.2 Language or Metaphysics

7.3 Visual Analogy

7.4 Animal

7.5 Memory or Retrieval

7.6 Logic

7.7 Various

8. Other

\section{Arts or Aesthetics}

Work in this section takes as its subject matter art or aesthetic considerations. While there is not a lot of work listed here, researchers are encouraged to examine work in the General or Wide Ranging sections that may be of relevance. For example, section 7.3 on visual analogy contains material on analogy that could be of interest to practitioners of the fine arts. Section 7.2 contains material on the 
relationship between metaphor and analogy that may be of interest to those studying literature. There is also work there that compares and contrasts the language(s) of art with language from other domains. Section 7.7 contains the most diverse collection of materials, some of which might prove interesting for those studying analogy in the arts.

\section{Normative Treatments of Action}

Some analogies take action as their subject matter. Work concerned with predicting or describing action using analogies is not listed in this section. The work listed here takes as its subject matter the normative treatment of action or related notions. Sometimes the analogy is about an action directly: action $x$ is immoral because it is analogous to action $y$, which is clearly immoral. Sometimes, the analogy is about a concept related to action. For example, it is possible to argue by analogy that $x$ constitutes a trade secret because $y$ is generally agreed to constitute a trade secret. While this is an argument about the legal concept of trade secret, it is clearly connected to action since trade secrets are protected by law, and actions can be classified as illegal if considered a violation of trade secret law. While this section is about the normative treatment of action, this does not mean that the subject matter of the analogy must be action in every instance. Sometimes, concepts or rules (used in normative reasoning about action) will be the primary subject matter of the analogy.

\subsection{Law}

One of the most familiar forms of reasoning by analogy can be found in law. There is a disputed case (the target), and someone reasons from analogous case (the source) to support some conclusion about the target. The target case is often distinguished from other possible sources. There has been much disagreement about how to understand analogical legal reasoning. While the work included in this section comes from a variety of disciplinary perspectives, it concerns mostly analogies in law in the English language legal traditions. Since this reference work is devoted primarily to work in English, this is not surprising. That said, there is work in English on analogy and case based reasoning in Islamic and Jewish law, and it has been included. Those interested in analogy in Islamic (specifically Suni) legal thought should research the term qiyas (an Arabic expression translated as analogy or analogical reasoning).

Case based reasoning (CBR) is a subfield of AI research that has intimate connections with analogy. Some of this work is in law; some of it pertains to other domains. That said, the work in Law and AI draws heavily on case based reasoners. Some of the work in this field, 
especially as it pertains to analogy, has been included. See the section on OTHER RESOURCES for how to find more work.

Precedent is a very important concept in law, so is the idea of following precedent or staying decided - stare decisis. Linked to these notions is the rationale on which a case is decided - the ratio decidendi. In setting a precedent, a court will generally announce its ratio decidendi which constrains future courts (though not absolutely) through the doctrine of stare decisis. Work by philosophers, jurists, argumentation theorists, and AI researchers have engaged all these notions in conjunction with analogical, and more generally, case based reasoning. Legal particularism is a view on the status of cases in legal reasoning, and it too is relevant to the views that have been held on analogy. While this reference work is not devoted to the key terms identified in bold, some work pertaining to those concepts (as they pertain to analogy) has been included. Researchers interested in more literature pertaining to the concepts identified in bold are (again) encouraged to consult the tools listed under Other Resources, especially those focusing on legal resources.

Argument scheme is an expression used largely by argumentation theorists and logicians. Work regarding the scheme(s) that appropriately describe analogical arguments and how it (they) relate to other schemes has been included. However, not all work on schemes has been included, just the work engaging analogy.

Some of the work in this section includes theorizing about analogies outside the law. For example Brewer (1996) offers a general theory of analogy (not just of analogy in the law). However, the vast majority of that paper deals with analogy in the law; all references to that paper that we have found are by philosophers of law or jurisprudential theorists, and the paper was published in the Harvard Law Review. So while a case could be made that some of the work in this section could have been placed in one of the General of Wide Ranging subsections, if we judged the work to be primarily and mostly of concern to those theorizing about analogy in the law, we placed it in this section.

\subsection{Ethics or Action}

Theorizing about the way analogy is used in ethical discourse is included in this section. So is theorizing about analogy that pertains to evaluating action more generally. Discussions of analogies in political or policy discourses are included here. Discussions of analogy that engage more than one area of evaluative discourse pertaining to action are included here as well. For example, work that examines analogy in ethics and law, or politics and law, or ethics and prudence fall in this section. Given that some work takes up discussion of analogy in more than one domain of action discourse, and given that there are disputes about how to delineate some of the domains of action discourse, it is useful to group these discourses on analogy together. 
Casuistry is an approach (or family of approaches) to moral reasoning (and reasoning about action more generally) stressing the importance of cases. Moral particularism refers to a family of moral philosophies stressing the importance of cases and downplaying (and sometimes rejecting entirely) the importance of rules. When theorists working in either of the aforementioned traditions engage analogy, their work is included. Those doing research on analogy as used in ethics, or action discourse more generally, may be interested in examining these approaches since some (though certainly not all) views on analogy are grounded in the theoretical presuppositions of these approaches. The notion of argument scheme may be useful to those doing research on analogy in action discourses beyond the law.

\section{Religion or Theology: Language, Logic, or Metaphysics}

While the work referenced in this section at least touches on religious or theological thought, it would be a mistake to think that the authors referenced here were only or even primarily interested in religious language. Some medieval thinkers were interested in providing theories of language, and analogy was part of the theory, and religious uses of language were engaged, but there was more to both the theory of analogy and the theory of language than its application to religious language. Some of this work is sufficiently general and wide ranging - engaging a variety of issues pertaining to the nature of language, logic, or metaphysics - that a case could be made that it should be included in one of the General or Wide Ranging sections below. That said, those doing research on analogy in religion may find it useful to have references engaging analogy in religious discourse collected in one section. Given citation patterns, this also makes sense: while Aquinas and Cajetan have views on analogy that go beyond its uses in religious discourse, more recent authors who cite their work on analogy are often writing about their views on religious language. Those interested in general discussions of analogy that do not engage religious discourse are encouraged to examine Section 7.

Metaphor and model come up in recent discussions of analogy in religious discourse. When these discussions explicitly engage the issue of analogy, they are included. However, not all work on metaphors and models is included. Researchers interested in analogy in religious language will likely find related discussions on metaphors and models to be useful. 


\section{Sciences or Engineering}

Analogies that take as their subject material from the natural and social, applied and theoretical sciences are included in this section. The exceptions are psychology and cognitive science (for reasons explained at the end of this section and in Section 6).

In discussions of analogy in science, there are two other terms that frequently appear: metaphors and models. Model based reasoning is another expression with increasing currency in discussions of scientific reasoning and engineering. There is no general agreement on the scope of any of these expressions. Black (1977, p. 30) has claimed that every metaphor is mediated by an analogy, and that "Every metaphor is the tip of submerged model." Not everyone holds such views. Bailer-Jones (2002, p.123) provides the example of gravitational lens as a case where metaphorical language is being used without there being any deep structure correspondences generally thought to be characteristic of analogies and models. As she points out, all that a gravitational lens and an optical lens have in common is the bending of light; the means by which light is bent are completely different, so it is far from obvious that there are any deep structural correspondences at work. Bailer-Jones (2002) provides a very useful survey discussion of different views on the relationship between analogies, metaphors, and models.

While this work does not purport to be a reference work on metaphors or models, there are reasons to include some work on these subjects. First, many have taken analogies to be in some way related to metaphor or models. Work that engages the nature of that relationship (regardless of the substantive position defended) is included. Also, some researchers doing work on analogy may be interested (and may see analogies) in what others refer to as metaphors and models.

Exemplar, paradigm, and prototype are also thought by some to be related to analogy. Work in the philosophy of science and engineering sometimes engages these concepts as they relate to analogy. "Exemplar" and "paradigm" tend to be common in discussions of science. Discussions of engineering tend to focus on the notion of "prototype." This latter notion is also used in a very different way in linguistics, psychology and cognitive science in presenting a theory of concepts. For example, bird is a concept that may be said to have more or less prototypical instances (robin or sparrow on the one hand as compared to ostrich or penguin on the other). When engineers talk about the importance of prototypes, they are not making a point about the theory of concepts but about how they reason from a past model or production to a current project.

In biology, similarity relations are delineated in different ways. Analogy, homology, and homoplasty are all similarity relations in this field. If two anatomical features perform the same or similar functions, they are said to be analogous. Two structures are said to be homologous 
if they share a common ancestry. If two structures have common function and common ancestry, then they are both analogous and homologous. Homoplasty exists if two structures are analogous but have different ancestries. Homology is also an important notion in genetics.

Quite a bit of work has been done on the use of analogies that take as their subject matter the mind or mental states. Philosophers have made many contributions in this area, and these contributions are often seen as part of the philosophy of mind. They are of interest to psychologists, cognitive scientists and others as well. The reverse is also true: psychologists and cognitive scientists have studied analogies that take mind or mental states as the subject matter, and this work is of interest to philosophers and others. A separate section has been created for analogies that take mind as their subject matter: Mind, Consciousness, or Cognition (Section 6 below). Also, much work in psychology and cognitive science studies analogy as it is related to developmental issues, memory, language processing and the like. The subject matters of the analogies in these inquiries varies dramatically, so much of that work is found in the various subsections of the General and Wide Ranging category (Section 7 below).

\section{Mathematics}

Research on the use of analogy in mathematics, whether for pedagogical or other reasons, is included in this section. For work that studies analogy in mathematics and other areas of reasoning, see the General or Wide Ranging sections.

The notions of isomorphism and homomorphism are important in defining structure preserving mappings. An analogy in mathematics is sometimes thought of in terms of a bijection that preserves some sort of structure. A morphism is the abstraction derived from a structure preserving map. A different approach to analogy in mathematics stresses an axiomatic approach, where laws or axioms are central to describing the analogy. Dirk Schlimm (2008) has done some outstanding and concise work in outlining different approaches to analogy in mathematics.

\section{Mind, Consciousness, or Cognition}

The works listed in this section are those where the analogies studied take as their subject matter one or more of mind, mentality, conscious or unconscious mental states, intentional states, cognition, or cognate matters. Studying analogy using a psychological or cognitive science approach is neither necessary nor sufficient for inclusion in this section. 
It is not necessary for the reason mentioned above: the study of analogies pertaining to the mind is not restricted to psychology or cognitive science. It is not sufficient because psychological and cognitive science approaches can be applied to analogies whose subject matter is not the mind. There is psychological and cognitive science work on analogy in the Mathematics section, and it is in that section because the subject matter of the analogy is mathematics. Indeed, work using psychological or cognitive science methodologies can be found throughout this reference work. From the fact that a psychological or cognitive science methodology is being used, it does not follow that the subject matter of the analogy is the mind or mental states. To be sure, minds are involved in doing analogical reasoning in mathematics, but then again, minds can be involved in doing analogical reasoning in any of the subject domains discussed herein, so minds being involved is simply not enough to classify work as belonging to this section. The type of analogy being discussed has to be explicitly about mind, mental states, or cognition to be in this section.

Philosophers, Psychologists, and Cognitive Scientists have engaged in debate over how we come to know about the existence of other minds or of mental states. In the early days, thinkers discussed the argument from analogy: other people behave the way I do in certain contexts; I know that I have mental states that give rise to those types of behaviour in those contexts, so other folks (by analogy) likely have (similar or the same type of) mental states I have that give rise to those types of behaviours in those contexts. This sort of argument from analogy is still discussed, and some of the discussion draws heavily on work in cognitive science and psychology. One strain of discussion has evolved largely into a debate between Theory-Theory and Simulation Theory (or Simulationism). Those subscribing to the former position emphasize the importance of an internally represented theory in attributing mental states to others; defenders of the latter approach stress the importance of an internal simulation of the target agent in order to attribute mental states to the target. Simulationism is most closely linked to the analogy approach to understanding other minds. While this reference work does not purport to extensively catalogue work on Simulationism, some work that discusses analogy has been included. Those interested in more should search either "Simulation Theory" (sometimes hyphenated) or "Simulationism."

\section{General or Wide Ranging}

Much work on analogy is not devoted to a particular subject matter. It is of a general nature. Some is wide ranging in the sense that it is explicitly devoted to more than one of the above categories. It may, for example, deal with analogy in law and one or more of the sciences, or analogy in mathematics and the sciences. Work in ethics and law is collected in the 
Ethics or Action section. Work devoted to other combinations of the above categories or that is very general in nature is collected in this section. There is quite a bit of work of a general or wide ranging nature, so some subdivisions are appropriate. Before getting to that, it would be useful to mention some words and expressions that would be useful for research on analogy.

Similarity is a term of significance in artificial intelligence, cognitive science, and psychology, and it has deep connections with analogy, though researchers generally agree that analogy and similarity are not the same thing. We will insist herein neither on (i) the exact senses of the different uses of similarity nor (ii) on a particular view of the relationship between similarity and analogy. While this work is not a bibliography devoted to similarity, some work on that subject as it is related to analogy has been included. Edwinna Rissland (2006) provides (a) an excellent introduction to and survey of the importance of similarity in AI, and (b) discusses similarity with respect to case based reasoning, analogy, exemplars, prototypes, and much more. Steven Sloman and Lance Rips (1998) edited a very useful collection of papers engaging the issue of similarity in psychology and cognitive science in a number of different ways. Researchers interested in analogy may also be interested in some of the work that has been done on similarity.

The notion of scheme also plays an important role in AI, psychology, and cognitive science. Argument scheme plays a role in argumentation theory and philosophy (especially logic). Mental models are discussed in psychology and cognitive science, and some of this work is also relevant to analogy.

Mental space mapping theory (also referred to as conceptual blending) is a more recent development in the literature in psychology and cognitive science. Fauconnier and Turner (2002) provide a useful overview of this approach, in which analogy plays a key role. Mental space mapping is different from the structure mapping approach found in the work of Gentner and many others.

All the key terms mentioned in this section have played a role in the general or wide ranging study of analogy. They have also played roles in more domain restricted work, but given the purported range of applicability of these notions, they were discussed in this section.

\subsection{Child Development, Learning, Pedagogy, and Problem Solving}

Some work that is general or wide ranging with respect to the topic of analogy is focused specifically on developmental issues in children, pedagogy, problem solving, or combinations of these - hence the subsection devoted to this collection of issues. Only developmental or pedagogical work of a general or wide ranging nature will be found in this section. Work that is devoted to the pedagogical uses of analogy in a specific domain covered in one of the above sections (for example, Mathematics) can be found in that section. 


\subsection{Language or Metaphysics}

General theorizing about the nature of language with applications to analogy; general theorizing about the nature of analogy for the purpose of improving our understanding of language or language processing, and either of the preceding as they relate to general issues in metaphysics all of these are included in this section. For example, what is metaphor? How is it related to analogy? Work attempting to answer such questions in a general or wide ranging manner is collected in this section. (Work devoted to metaphor and analogy in the sciences is found in the Sciences or Engineering section. Other focused work can be found in its respective section.) General discussions of metaphysical (but not religious) analogies are included in this section

\subsection{Visual Analogy}

Not all researchers believe that analogies have to be expressed in a linguistic manner. Visual analogies have to do with analogies between pictures, images, or anything having visual content not in a sentential form. Some work on visual analogies is included in other sections. For example, with respect to visual analogies having a mathematical subject matter, work theorizing about such analogies is included in the Mathematics section. However, some work on visual analogy is sufficiently general that it has been collected and placed in this section.

\subsection{Animal}

Work has been done on whether and to what extent animals can engage in analogical reasoning or problem solving. It has been collected in this section. The issue is not whether animals are the subject matter of the analogy. The subject matter of the analogy can vary. Work dedicated to whether animals have a theory of mind or whether they reason analogically about the mental states of other beings is included in the Mind, Consciousness, or Cognition section.

\subsection{Memory or Retrieval}

There is some work on analogy where the subject matter of the analogy itself is general or wide ranging, but the focus of the work is on retrieving an analogue from memory. In some cases, the memory at issue is human memory; in other cases, the memory is computer memory (where there may or not be claims about the relationship to human memory). Such work is collected in this section. Work on retrieval of analogies specific to a subject - such as law - can be found in the appropriate section above.

\subsection{Logic}

Work included in this section takes as the subject matter of analogy logic or some part of logic (for example, logical form or logical operators). Since logical forms are general in nature and can be instantiated in a number of different domains, work on logic has been included as a 
subsection of the General or Wide Ranging section. Not all work pertaining to logic is included in this subsection. Far from it. Logical reconstructions of analogy can be found throughout this reference work. For example, reconstructions of the logic of analogy in legal discourse can be found in the subsection devoted to law. General discussions of the logical structure of analogy, analogical argument, or analogical reasoning (where the subject matter of the analogy varies) can be found in the next subsection (Various). When the subject matter of the analogy itself is logic or a logical structure or operator, then theorizing about such analogies is included in the Logic subsection.

\subsection{Various}

Work that is sufficiently general or wide ranging but does not fit in the above subsections has been included in this subsection.

\section{Other}

Some work on analogy is very focused, so it would be inappropriate to classify it under General or Wide Ranging, yet none of the above categories is appropriate for this focused work. It has been collected here.

\section{Further Resources}

There is a variety of resources that allow for online searches for work on analogy. Some of these resources allow for access to resources not listed in this work. For example, with the exceptions listed above, not all conference proceedings papers have been included here. Some of the resources below allow for a searching of these and other resources.

The Association for Computing Machinery (ACM, http:/www.acm.org/) maintains a Digital Library (http://portal.acm.org/dl.cfm). Search for any ACM publication and retrieve the full text of journal and magazine articles, conference proceedings papers and more. For those interested in conference proceedings for the International Conference for Artificial Intelligence and Law (ICAIL), go to the ACM Digital Library home page (second link in this paragraph); click on "Proceedings", and then scroll and click "ICAIL" to see a list of conference proceedings for that group. Lots of work here on case based reasoning, some of which pertains to analogy. Website requires payment for proceedings and videos.

The American Psychological Association (APA, http://www.apa.org/publications/) allows for online searches of all its publications, including conference proceedings. Both PsycINFO and 
100 Marcello Guarini et al.

PsycARTICLES are available through the APA databases. Databases run through PsycNET, which requires subscription.

Cambridge University Press (http://www.cambridge.org/) is a major humanities and science publisher. Online searches of its books and journals are available. Books need to be paid for singly; journals mostly require subscription, though some have free content (marked by a red "F"), or trial access (marked by a green "T").

The Cognitive Science Society (CSS, http://www.cogsci.rpi.edu/CSJarchive/) allows for free online searches of all its publications, including conference proceedings. Free downloadable .pdf versions of papers.

The Collection of Computer Science Bibliographies

(http://liinwww.ira.uka.de/bibliography/) provides online search for journals, magazines and books (including conference proceedings). This is a free online resource.

Elsevier (http://www.elsevier.com/) is a major science and humanities publisher and offers online searches and text access. Aside from some free sample issues of journals, content requires a subscription.

Hein Online (http://heinonline.org/) provides searches and text access to law reviews and periodicals. Access to content requires a subscription.

The Institute of Electrical and Electronics Engineers (IEEE, http://www.ieee.org/portal/site) allows for searches and text access of their digital library. Free trials available, but content otherwise requires a subscriptions.

The ISI Web of Knowledge (http://apps.isiknowledge.com/) provides searches and text access to a very wide range of Humanities and Science sources. Content requires a subscription.

JSTOR (http://www.jstor.org/) provides access to journals in a widerange of fields including those in the humanities and sciences. Content requires a subscription.

LegalTrac (http://find.galegroup.com/) provides searches and text access to law reviews and periodicals. Access requires a subscription.

LexisNexis (http://academic.lexisnexis.com/online-services/academicoverview.aspx) provides searches and text access to law reviews and periodicals. Subscription required. 
LLMC Digital (http://www.llmcdigital.org/) provides searches and text access to law reviews and periodicals. Subscription required.

MITCogNet (http://cognet.mit.edu/library/) provides free online search for MIT press books, journals, and reference works. Major publisher in AI, Cognitive Science, Linguistics, Psychology, and Philosophy. Journals require subscription. Books can be purchased separately.

Oxford University Press (http://www.oup.co.uk/) is a major humanities and science publisher. Free online searches of their books and journals are available. Journals require subscription. Books can be purchased separately.

The Philosopher's Index (http://www.philinfo.org/) provides search for periodicals and books in all areas of philosophy. Major conference proceedings published as bound anthologies are also included.

Subscription required.

ScienceDirect offers journals from the physical sciences and engineering, life sciences, health sciences, social sciences and humanities. Content requires a subscription.

Springer (http://www.springer.com/) is a major science and humanities publisher and offers online searches and text access, including access to Lecture Notes in Computer Science. Many conference proceedings can be found here. Abstracts can be read for free, but other content requires a subscription.

Wiley InterScience (http://www3.interscience.wiley.com/) allows for searches and text access of Blackwell and Wiley sources. Humanities and science resources are available. Content requires a subscription.

Wilson Web (http://vnweb.hwwilsonweb.com/hww/login.jhtml) provides searches and text access to a very wide range of humanities and science sources. Content requires a subscription. 
102 Marcello Guarini et al.

\section{REFERENCES}

\section{Arts OR AESTHETICS}

1. Froehlich, Hildegard C. 1991. Language, Metaphor, and Analogy in the Music Education Research Process. Journal of Aesthetic Education (Fall): 243-257.

2. Hutchings, Patrick. 1969. Ontology and Analogy: their Relevance for Aesthetics. Philosophical Studies (Ireland) 18: 184-188.

3. Hutchings, Patrick. 1967. Works of Art and the Ontology of Analogy. Philosophical Studies (Ireland) 16: 82-103.

4. LaGuardia, Eric. 1968. Aesthetics of Analogy. Diogenes 62 (Summer): 49-61.

5. Mathauser, Zdenek. 2000. The Model of an Artistic Situation. Theoria: Revista de Teoria, Historia y Fundamentos de la Ciencia 15, no. 39 (September): 497-513.

6. Peltz, Richard W. 1969. Further Reflections on Art, Ontology and Analogy. Philosophical Studies (Ireland) 18: 178-184.

7. Roberts, Louise N. 1980. The Role of Analogues in Ballard's Aesthetics. Tulane Studies in Philosophy 29 (December): 109118.

8. Scruton, Roger. 1974. Art and imagination. London: Methuen.

9. Sharpe, R. A. 1975. 'Hearing As'. British Journal of Aesthetics 15, no. 3 (Summer): 217-225.

10. Stroud, Scott R. 2003. Analogical Thinking and Aesthetic Response: Emergent Images of the Philosopher in the Analects and the Apology. Kinesis: Graduate Journal in Philosophy 30, no. 2 (Fall): 41-61.

11. Thomas, Troy. 1991. Interart Analogy: Practice and Theory in Comparing the Arts. Journal of Aesthetic Education (Summer): 17-36.

\section{Normative Treatments of ACtion}

\subsection{LAW}

1. Aikenhead, Michael. 1996. The Uses and Abuses of Neural Networks in Law. Computer \& High Technology Law Journal 12, no. 1: 31-70. 
Resources for Research on Analogy 103

2. Aldisert, Ruggero J. 1989. Logic for lawyers: A guide to clear legal thinking. New York, N.Y.: C. Boardman Co.

3. Alexander, Larry. 1998. The Banality of Legal Reasoning. Notre Dame Law Review 73, no. 3 (March): 517-533.

4. Alexander, Larry. 1996. Bad Beginnings. University of Pennsylvania Law Review 145: 57-87.

5. Alexander, Larry. 1989. Constrained by Precedent. Southern California Law Review 63: 1-64.

6. Alexander, Larry, Kenneth Kress. 1995. Against legal principles. In Law and interpretation. Edited by A. Marmor. Oxford: Oxford University Press.

7. Alexander, Larry, and Emily Sherwin. 2008. Demystifying legal reasoning. Cambridge: Cambridge University press.

8. al-Faruque, Muhammad. 1997. Sources on Islamic Family Law: An Introductory Essay. Canadian Law Libraries/ Bibliotheques de Droit Canadiennes 22, no. 2: 50-54.

9. Anderson, R. O. 1969. Conclusive Analogical Arguments. Revue Internationale de Philosophie 23: 44-57.

10. Ashley, Kevin D. 1991. Reasoning with Case and Hypotheticals in HYPO. International Journal of Man-Machine Studies 34: 753-796.

11. Ashley, Kevin D. 1990. Modelling legal argument: Reasoning by cases and hypotheticals. Cambridge, MA.; and London, England: MIT Press, A Bradford Book.

12. Ashley, Kevin D. 1988. Arguing by analogy in law. In Analogical reasoning. Edited by D. H. Helman. Dordrecht: Kluwer.

13. Ashley, Kevin D., Edwina L. Rissland. 1988. Case-Based Approach to Modelling to Legal Expertise. IEEE Expert 3, no. 3 (September): 70-77.

14. Atiyah, Patrick S. 1985. Common law and statute law. The Modern Law Review 48, no. 1: 1-28.

15. Atkinson, Katie, Bench-Capon, Trevor J. M. 2005. Legal CaseBased Reasoning as Practical Reasoning. Artificial Intelligence and Law 13, no. 1 (March): 93-131.

16. Balkin, Jack M. 1987. Deconstructive Practice and Legal Theory. Yale Law Journal 96: 743-786.

17. Bathaee, Yavar. 2007. Incompletely Theorized Agreements: An Unworkable Theory of Judicial Modesty. Fordham Urban Law Journal: 1457-1488. 
104 Marcello Guarini et al.

18. Becker, Lawrence C. 1973. Analogy in Legal Reasoning. Ethics 83, no. 3 (April): 248-255.

19. Bench-Capon, Trevor J. M. 2002. The Missing Link Revisited: The Role of Teleology in Representing Legal Argument. Artificial Intelligence and Law 10, no. 1-3 (September): 79-94.

20. Bench-Capon, Trevor J. M. 1997. Argument in Artificial Intelligence and Law. Artificial Intelligence and Law 5, no. 4 (December): 249-261.

21. Bench-Capon, Trevor J. M., Giovanni Sartor. 2003. A Model of Legal Reasoning with Cases Incorporating Theories and Values. Artificial Intelligence 150, no. 1-2 (November): 97-143.

22. Bench-Capon, Trevor J. M., Giovanni Sartor. 2000. Using values and theories to resolve disagreement in law. In Legal knowledge and information systems: Jurix 2000. Edited by J. Breuker, R. Leenes and R. Winkels. Amsterdam: IOS Press.

23. Bentham, Jeremy. 1998. Legislator of the world: Writings on codification, law and education. Oxford, UK.: Clarendon Press.

24. Bentham, Jeremy. 1977. A comment on the commentaries and a fragment on government. London: Athlone Press.

25. Bentham, Jeremy. 1970. Of laws in general. London: Athlone Press.

26. Bentham, Jeremy, and John Bowring. 1843. The works of Jeremy Bentham. Edinburgh; London: W. Tait; Simpkin, Marshall, \& co.

27. Bickel, Alexander M. 1978. The supreme court and the idea of progress. New Haven: Yale University Press.

28. Blasi, Gary L. 1995. What Lawyers Know: Lawyering Expertise, Cognitive Science, and the Functions of Theory. Journal of Legal Education 45: 313-397.

29. Borsellino, Patrizia. 1985. L'analogia Nella Logica Del Diritto: Un Contributo Di Norberto Bobbio Alla Metodologia Giuridica. Rivista Internazionale di Filosofia del Diritto 6, pt. 2 (JanuaryMarch): 3-39.

30. Branting, L. K. 2003. A Reduction-Graph Model of Precedent in Legal Analysis. Artificial Intelligence 150, no. 1-2 (November): 59-95.

31. Branting, L. K. 2000. Reasoning with rules and precedents: A computational model of legal analysis. Dordrecht ; Boston: Kluwer Academic Publishers. 
Resources for Research on Analogy 105

32. Branting, L. K. 1991. Reasoning with Portions of Precedents. Proceedings of the Third International Conference on Artificial Intelligence and Law: 145-154.

33. Brennan, Patrick M. 1998. Discovering the Archimedean Element in (Judicial) Judgment. Law and Philosophy: An International Journal for Jurisprudence and Legal Philosophy 1, pt. 7, no. 2 (March): 177-192.

34. Brewer, Scott ed. 1998. Scientific models of legal reasoning: Economics, artificial intelligence, and the physical sciences. Routlege.

35. Brewer, Scott. 1996. Exemplary Reasoning: Semantics, Pragmatics and the Rational Force of Legal Argument by Analogy. Harvard Law Review, no. 109: 923-1027.

36. Brkic, Jovan. 1975. Logical analysis of similarity and analogy with respect to the logic of law. In 15th world congress of philosophy, proceedings. Edited by Anonymous Sofia: Sofia Press Production Centre.

37. Buchanan, Bruce, Thomas E. Headrick. 1970. Some Speculation About Artificial Intelligence and Legal Reasoning. Stanford Law Review 23, no. 1: 40-62.

38. Burton, Steven J. 1985. An introduction to law and legal reasoning. Boston: Little, Brown.

39. Cap, Piotr. 2006. Metaphor and Political Discourse: Analogical Reasoning in Debates About Europe. Journal of Pragmatics 38, no. 3 (March): 460-463.

40. Caplan, Arthur. The doctors' trial and analogies to the holocaust in contemporary bioethical debates. In The nazi doctors and the nuremberg code: Human rights in human experimentation. Edited by G. J. Annas and M. A. Grodin. New York: Oxford University Press.

41. Cardozo, Benjamin N. 1968. The nature of the judicial process. New Haven: Yale University Press.

42. Chapman, Bruce. 1994. The Rational and the Reasonable: Social Choice Theory and Adjudication. University of Chicago Law Review 61: 41-122.

43. Chorley, Alison, Bench-Capon, Trevor J. M. 2005. An Empirical Investigation of Reasoning with Legal Cases Through Theory Construction and Application. Artificial Intelligence and Law 13, no. 3-4 (December): 323-371. 
Marcello Guarini et al.

44. Cross, Rupert, and J. W. Harris. 1991. Precedent in english law. Oxford, England; Toronto: Clarendon Press; Oxford University Press.

45. Daniels, Jody J., Edwina L. Rissland. 1995. A Case-Based Approach to Intelligent Information Retrieval. Proceedings of the 18th Annual International ACM SIGIR Conference on Research and Development in Information Retrieval: 238-245.

46. Detmold, Michael J. 1984. The unity of law and morality: A refutation of legal positivism. London, England: Routledge \& Kegan Paul Books.

47. Devenish, George. 1991. The Nature of Legal Reasoning Involved in the Interpretation of Statutes. Stellenbosch Law Review 2: 224-241.

48. Dickson, Julie. Interpretation and coherence in legal reasoning. Friday July 1 2005. Internet on-line. Available from $<$ http://www.seop.leeds.ac.uk/archives/spr2007/entries/legal-reasinterpret/>.

49. Dworkin, Ronald. 1997. In Praise of Theory. Arizona State Law Journal 29, no. 2: 353-376.

50. Dworkin, Ronald. 1986. Law's empire. Cambridge, Mass.: Belknap Press.

51. Dworkin, Ronald. 1977. Taking rights seriously. Cambridge: Harvard University Press.

52. Edwards, Linda H. 1996. The Convergence of Analogical and Dialectic Imaginations in Legal Discourse. Legal Studies Forum 20: 7-50.

53. Eisenberg, Melvin A. 1988. The nature of the common law. Cambridge, Mass: Harvard University Press.

54. Elster, Jon. 1992. Local justice: How institutions allocate scarce goods and necessary burdens. New York: Russell Sage Foundation.

55. Englard, Izhak. 1985. The Example of Medicine in Law and Equity: On a Methodological Analogy in Classical and Jewish Thought. Oxford Journal of Legal Studies 5: 238-247.

56. Ferrari, Silvio. 2006-2007. Adapting Divine Law to Change: The Experience of the Roman Catholic Church (with Some Reference to Jewish and Islamic Law). Cardozo Law Review 28: 53-66.

57. Feteris, Eveline. 2005. The Rational Reconstruction of Complex Forms of Legal Argumentation: Approaches from Artificial 
Intelligence and Law and Pragma-Dialectics. Argumentation: An International Journal on Reasoning 19, no. 4: 393-400.

58. Feteris, Eveline. A Survey of 25 Years of Research on Legal Argumentation. Argumentation: An International Journal on Reasoning 11, no. 3: 355-376.

59. French, Robert M. 1989. An Analogy Between Western Legal Traditions and Approaches to Artificial Intelligence. AI and Society 3, no. 3: 229-234.

60. Fried, Charles. 1981. The Artificial Reason of the Law or: What Lawyers Know. Texas Law Review 60: 35-58.

61. Fuller, Lon L. 1968. The anatomy of law. New York: F.A. Praeger.

62. Gardner, Anne von der Lieth. 1987. An artificial intelligence approach to legal reasoning. Cambridge, Mass.: MIT Press.

63. Gaus, Gerald F. 1990. Value and justification: The foundations of liberal theory. Cambridge England ; New York: Cambridge University Press.

64. Gilovich, Thomas. 1981. Seeing the Past in the Present: The Effect of Associations to Familiar Events on Judgments and Decisions. Journal of Personality and Social Psychology 40: 797808.

65. Giovannetti, Dana. 1984. The Principle of Analogy in Sino-Soviet Criminal Laws. Dalhousie Law Journal 8: 382-401.

66. Godden, David M., Douglas Walton. 2008. Defeasibility in Judicial Opinion: Logical or Procedural? Informal Logic 28, no. 1: 6-19.

67. Goldfarb, Phyllis. 1989-1990. When Judges Abandon Analogy: The Problem of Delay in Commencing Criminal Prosecutions. William \& Mary Law Review 31: 607-680.

68. Golding, Andrew R., Paul S. Rosenbloom. November, 1996. Improving Accuracy by Combining Rule-Based and Case-Based Reasoning. Artificial Intelligence 87, no. 1-2: 215-254.

69. Golding, Martin P. 1983. Legal reasoning. New York: A.A. Knopf.

70. Goldstein, Laurence. 1987. Precedent in law. Oxford: Oxford University Press.

71. Goodhart, Arthur L. 1959. The Ratio Decidendi of a Case. The Modern Law Review 22, no. 2: 117-124. 
108 Marcello Guarini et al.

72. Goodhart, Arthur L. 1930. Determining the Ratio Decidendi of a Case. Yale Law Journal 40, no. 2 (December): 161-183.

73. Goodrich, Peter. 1986. Reading the law: A critical introduction to legal method and techniques. Oxford, OX, UK ; New York, NY: B. Blackwell.

74. Gordon, Thomas F. 1995. The pleadings game: An artificial intelligence model of procedural justice. Boston: Kluwer Academic Publishers.

75. Gray, Pamela N. 1997. Artificial legal intelligence. Brookfield, VT: Dartmouth.

76. Grey, Thomas C. 1983. Langdell's Orthodoxy. University of Pittsburg Law Review 45: 1-16.

77. Gunasekara, Gehan N. 1998. Judicial Reasoning by Analogy with Statutes: Now an Accepted Technique in New Zealand? Statute Law Review 19, no. 3: 177-201.

78. Gunasekara, Gehan N. 1993. Judicial Reasoning by Analogy with Statutes: The Case of Contributory Negligence and the Law of Contract in New Zealand. Statute Law Review 14: 84-110.

79. Gwynne, Rosalind W. 2004. Logic, rhetoric and and legal reasoning in the qur'an: God's arguments. London; New York: RoutledgeCurzon.

80. Hafner, Carole, Donald H. Berman. 2002. The Role of Context in Case-Based Legal Reasoning: Teleological, Temporal and Procedural. Artificial Intelligence and Law 10, no. 1-3: 19-64.

81. Hage, Jaap. 2005. The Logic of Analogy in the Law. Argumentation: An International Journal on Reasoning 19, no. 4: 401-415.

82. Hage, Jaap. 2005. Studies in legal logic. Dordrecht: Springer.

83. Hage, Jaap. 2003. Legal Reasoning and Legal Integration. Maastricht Journal of European and Comparative Law 10, no. 1: 67-97.

84. Hage, Jaap. 2001. Formalizing Legal Coherence. Proceedings of the 8th International Conference on Artificial Intelligence and Law: 22-31.

85. Hage, Jaap. 2001. Legal logic, it's existence, nature and use. In Pluralism and law. Edited by A. Soeteman. Dordrecht: Kluwer.

86. Hall, Clifford. 1973. Validity Criteria and the Problem of Choice. Cambrian Law Review 4: 45-57. 
87. Hallaq, Wael B. 1989. Non-Analogical Arguments in Sunni Juridical Qiyās. Arabica 36, no. 3 (Nov.): 286-306.

88. Hallaq, Wael B. 1985-1986. The Logic of Legal Reasoning in Religious and Non-Religious Cultures: The Case of Islamic Law and the Common Law. Cleveland State Law Review 34: 79-96.

89. Hammond, Kristian. 1989. Case-based planning: Viewing planning as a memory task. New York: Academic Press.

90. Hart, H. L. A. 1994. The concept of law. Oxford; New York: Clarendon Press; Oxford University Press.

91. Hasan, Ahmad. 1992. Analogical reasoning in islamic jurisprudence: A study of the islamic principle of qiyas. Islamabad; Pakistan: Islamic Research Institute.

92. Hoeflich, Michael H. 1986. Law and Geometry: Legal Science from Leibniz to Langdell. American Journal of Legal History 30, no. 2: 95-121.

93. Hollatz, Jürgen. 1999. Analogy Making in Legal Reasoning with Neural Networks and Fuzzy Logic. Artificial Intelligence and Law 7, no. 2-3: 289-301.

94. Holmes, Oliver W. 1982. The common law \& other writings. Birmingham, Ala.: Legal Classics Library.

95. Horwitz, Morton J. 1992. The transformation of American law, 1870-1960: The crisis of legal orthodoxy. New York: Oxford University Press.

96. Hricik, David. 2003-2004. Reading Too Much into Nothing: The Metaphor of Place and the Internet. Mercer Law Review 55: 859866.

97. Huhn, Wilson. 2003. The Stages of Legal Reasoning: Formalism, Analogy, and Realism. Villanova Law Review 48: 305-380.

98. Hunter, Dan. 2001. Reason is too Large: Analogy and Precedent in Law. Emory Law Journal 50: 1197-1264.

99. Hunter, Dan. 1998. No Wilderness of Single Instances: Inductive Inference in Law. Journal of Legal Education 48: 365-401.

100. Hurley, Susan L. 1990. Coherence, Hypothetical Cases, and Precedent. Oxford Journal of Legal Studies 10: 221-251.

101. Hutchinson, Allan C. 1998. The Reasoning Game: Some Pragmatic Suggestions. Modern Law Review 61: 263-280.

102. Jansen, Henrike. 2005. E Contrario Reasoning: The Dilemma of the Silent Legislator. Argumentation: An International Journal on Reasoning 19, no. 4: 485-496. 
110 Marcello Guarini et al.

103. Kamali, Mohammad H. 2005. Equity and fairness in Islam. Cambridge: Islam Text Society.

104. Kamali, Mohammad H. 2003. Principles of islamic jurisprudence. Islamic Text Society.

105. Kamali, Mohammad H. 1996. Methodological Issues in Islamic Jurisprudence. Arab Law Quarterly 11, no. 1: 3-33.

106. Kamm, F. M. 1997. Theory and analogy in law. Arizona State Law Journal 29405.

107. Kaptein, Hendrik. 2005. Legal Progress Through PragmaDialectics? Prospects Beyond Analogy and E Contrario. Argumentation: An International Journal on Reasoning 19, no. 4: 497-507.

108. Kennedy, Duncan. 1976. Form and Substance in Private Law Adjudication. Harvard Law Review 89: 1685-1687-1713.

109. Khadduri, Majid. 1984. The islamic conception of justice. Baltimore: Johns Hopkins University Press.

110. Khadduri, Majid. 1953-1954. Nature and Sources of Islamic Law. George Washington Law Review 22: 3-23.

111. Kloosterhuis, Harm. 2005. Reconstructing Complex Analogy Argumentation in Judicial Decisions: A Pragma-Dialectical Perspective. Argumentation: An International Journal on Reasoning 19, no. 4: 471-483.

112. Kloosterhuis, Harm. 2002. Van overeenkomstage toepassing. de pragma-dialectische re-constructie van analogie-argumentatie.

113. Kloosterhuis, Harm. 2000. Analogy Argumentation in Law: A Dialectical Perspective. Artificial Intelligence and Law 8, no. 2-3: 173-187.

114. Klug, Ulrich. 1982. Juristische logik. Berlin e.a.: Springer Verlag.

115. Kronman, Anthony T. 1993. The lost lawyer: Failing ideals of the legal profession. Cambridge, Mass.: Belknap Press of Harvard University Press.

116. Kronman, Anthony T. 1990. Precedent and Tradition. Yale Law Journal 99: 1029-1068.

117. Lamond, Grant. 2005. Do Precedents Create Rules? Legal Theory 11, no. 1: 1-26.

118. Langenbucher, Katja. 1998. Argument by Analogy in European Law. Cambridge Law Journal 57, no. 3: 481-521.

119. Levenbook, Barbara. 2000. The Meaning of a Precedent. Legal Theory 6, no. 2 (June): 185-240. 
Resources for Research on Analogy 111

120. Levi, Edward, H. 1949. An introduction to legal reasoning. Chicago, and London.: University of Chicago Press.

121. Levin, Joel. 1983. The Concept of the Judicial Decision. Case Western Reserve Law Review 33: 208-239.

122. Litman, Donna. 2004-2005. Jewish Law: Deciphering the Code by Global Process and Analogy. University of Detroit Mercy Law Review 82: 563-598.

123. Llewellyn, Karl N. 1996. The common law tradition: Deciding appeals. Buffalo, N.Y.: W.S. Hein.

124. MacCormick, D. N. 1998. The Significance of Precedent. Acta Juridica: 174-187.

125. MacCormick, D. N. 1989. Legal reasoning and interpretation. In Encyclopedia of philosophy. Edited by E. Craig. London: Routledge.

126. MacCormick, D. N. 1978 (1994). Legal reasoning and legal theory. Oxford: Oxford University Press.

127. MacCormick, D. N., and Robert S. Summers ed. 1997. Interpreting precedents: A comparative study. Aldershot: Dartmouth.

128. Markman, Arthur B., C. P. Moreau. 2001. Analogy and analogical comparison in choice. In The analogical mind. Edited by D. Gentner, K. J. Holyoak and B. N. Kokinov. Cambridge, Mass.; London, England: MIT Press/ A Bradford Book.

129. Martin, Michael. 1995. Skepticism About Legal Reasoning. Communication and Cognition: An Interdisciplinary Quarterly Journal 28, no. 1: 55-76.

130. Mcbride, William L. 1968. The Essential Role of Models and Analogies in the Philosophy of Law. New York University Law Review 43 (March): 53-87.

131. McJohn, Stephen M. 1993. On Uberty: Legal Reasoning by Analogy and Peirce's Theory of Abduction. Williamette Law Review 29: 191-236.

132. Montrose, J. L. 1957. The Ratio Decidendi of a Case. Modern Law Review 20: 587-595.

133. Montrose, J. L. 1957. Ratio Decidendi and the House of Lords. Modern Law Review 20, no. 2: 124-130.

134. Moravcsik, Julius M. 2000. Health, Healing, and Plato's Ethics. Journal of Value Inquiry 3, pt. 4, no. 1 (March): 7-26. 
112 Marcello Guarini et al.

135. Murray, Daniel E. 1971. Under the Spreading Analogy of article 2 of the Uniform Commercial Code. Fordham Law Review 477: 480.

136. Murray, James R. 1981-1982. The Role of Analogy in Legal Reasoning. UCLA Law Review 29: 833-871.

137. Naucke, Wolfgang. 1986. Interpretation and Analogy in Criminal Law. Brigham Young University Law Review: 535-552.

138. Nedzel, Nadia E. 2004. Legal reasoning, research, and writing for international graduate students. New York, NY: Aspen Publishers.

139. Nerhot, Patrick ed. 1990. Legal knowledge and analogy: Fragments of legal epistemology, hermeneutics and linguistics. Kluwer Academic Publishers.

140. Perelman, Chaïm. 1980. Justice, law and argument. Dordrecht: Reidel.

141. Perry, Stephen. 1997. Two Models of Legal Principles. Iowa Law Review 82, no. 3: 787-819.

142. Perry, Stephen. 1987. Judicial Obligation, Precedent and the Common Law. Oxford Journal of Legal Studies 7, no. 2: 215-257.

143. Peschka, Vilmos. 1980. Type and Analogy in Law (In German). Archiv fuer Rechts- und Sozialphilosophie 66: 85-99.

144. Posner, Richard A. 1995. Overcoming law. Cambridge, Mass.: Harvard University Press.

145. Posner, Richard A. 1990. The problems of jurisprudence. Cambridge, Mass.: Harvard University Press.

146. Posner, Richard A. 1986. Legal Formalism, Legal Realism, and the Interpretation of Statutes and the Constitution. Case W. Wes. Law Review 37: 179-187.

147. Posner, Richard A. 1981. The economics of justice. Cambridge, Mass.: Harvard University Press.

148. Postema, Gerald J. 2007. A similibus ad similia: Analogical thinking in law. In Common law theory. Edited by D. E. Edlin. Cambridge: Cambridge University Press.

149. Postema, Gerald J. 2002. Philosophy of common law. In The oxford handbook of jurisprudence and philosophy of law. Edited by J. Coleman and S. Shapiro. Oxford, UK.: Oxford University Press.

150. Postema, Gerald J. 1997. Integrity: Justice in Workclothes. Iowa Law Review 82: 821-855. 
151. Postema, Gerald J. 1994. Implicit Law. Law and Philosophy 13: 361-387.

152. Postema, Gerald J. 1986. Bentham and the common law tradition. Oxford: Clarendon Press.

153. Pound, Roscoe. 1960. Law finding through experience and reason: Three lectures. Athens: University of Georgia Press.

154. Prakken, Henry. 2000. An exercise in formalising teleological case based reasoning. In Legal knowledge and information systems: Jurix 2000. Edited by J. Breuker, R. Leenes and R. Winkels. Amsterdam: IOS Press.

155. Prakken, Henry. 1997. Logical tools for modelling legal argument. A study of defeasible reasoning in law. Dordrecht: Kluwer.

156. Prakken, Henry, Giovanni Sartor. 1998. Modelling Reasoning with Precedents in a Formal Dialogue Game. Artificial Intelligence and Law 6, no. 2-4: 231-287.

157. Prakken, Henry, Giovanni Sartor. 1996. A Dialectical Model of Assessing Conflicting Arguments in Legal Reasoning. Artificial Intelligence and Law 4, no. 3-4: 331-368.

158. Preuss, Lawrence. 1936. Punishment by Analogy in National Socialist Penal Law. Journal of Criminal Law and Criminology (1931-1951) 26, no. 6 (Mar.): 847-856.

159. Raz, Joseph. 1979. The authority of law: Essays on law and morality. Oxford; New York: Clarendon Press; Oxford University Press.

160. Raz, Joseph. 1975. Practical reason and norms. London: Hutchinson.

161. Rinaldi, Fiori. 1971. Is Analogy a Decision Process in English Law? Logique et Analyse 14 (March-June): 363-374.

162. Rissland, Edwina L. 1989-1990. Artificial Intelligence and Law: Stepping Stones to a Model of Legal Reasoning. Yale Law Journal 99: 1957-1982.

163. Rissland, Edwina L., David B. Skalak. June 1991. CABARET: Rule Interpretation in a Hybrid Architecture. International Journal of Man-Machine Studies 34, no. 6: 839-887.

164. Roth, Bram. 2003. Case-based reasoning in the law. A formal theory of reasoning by case comparison.

165. Roth, Bram. 2000. New reasoning patterns in analogical case based reasoning: An informal investigation. In Legal knowledge 
114 Marcello Guarini et al.

and information systems: Jurix 2000. Edited by J. Breuker, R. Leenes and R. Winkels. Amsterdam: IOS Press.

166. Rush, Sharon E. 1997. Equal Protection Analogies--Identity and Passing: Race and Sexual Orientation. Harv. Blackletter L. J. 13: 65-106.

167. Sartor, Giovanni. 2002. Teleological Arguments and TheoryBased Dialectics. Artificial Intelligencve and Law 10, no. 1-3 (September): 95-112.

168. Sartor, Giovanni. 1993. Artificial intelligence and law: Legal philosophy and legal theory. Oslo: Tano.

169. Sartor, Giovanni, and L. K. Branting ed. 1998. Judicial applications of artificial intelligence. Dordrecht: Kluwer Academic Publishers.

170. Sartorius, Rolf. 1967. The Doctrine of Precedent and the Problem of Relevance. Archiv für Rechts und Sozialphilosophie 53: 343365.

171. Scafidi, Susan. 2003. Old Law in the New World: Solorzano and the Analogical Construction of Legal Identity. Florida Law Review 55: 191-204.

172. Scalia, Antonin. 1989. The Rule of Law as a Law of Rules. The University of Chicago Law Review 56, no. 4: 1175-1188.

173. Schauer, Frederick F. 1991. Playing by the rules: A philosophical examination of rule-based decision-making in law and in life. Oxford, England; New York: Clarendon Press; Oxford University Press.

174. Schauer, Frederick F. 1989. Is the Common Law Law? California Law Review 77: 455-471.

175. Schauer, Frederick F. 1987. Precedent. Stanford Law Review 39: 571-605.

176. Schauer, Frederick F. 1985. Slippery Slopes. Harvard Law Review 361: 381-383.

177. Schellens, Peter J., Menno De Jong. 2004. Argumentation Schemes in Persuasive Brochures. Argumentation: An International Journal on Reasoning 18, no. 3: 295-323.

178. Schiavello, Aldo. 1992. Legal Knowledge and Analogy (Book Review). Rivista Internazionale di Filosofia del Diritto 69, no. 4: 652-654. 
179. Schild, Uri J., Shai Herzog. 1993. The Use of Meta-Rules in Rules Based Legal Computer Systems. Proceedings of the Fourth International Conference of AI and Law: 100-109.

180. Sherwin, Emily. 2006. Judges as Rulemakers. University of Chicago Law Review 73: 919-932.

181. Sherwin, Emily. 1999. A Defense of Analogical Reasoning in Law. University of Chicago Law Review 66, no. 4 (Autumn): 1179-1197.

182. Silving, Helen. 1967. Analogy and Extensive Interpretation. Revista Juridica de la Universidad de Puerto Rico 36: 311-316.

183. Simitis, Spiros. 1960. The Problem of Legal Logic. Ratio: An International Journal of Analytic Philosophy 3 (December): 6094.

184. Simmonds, Nigel E. 1984. The decline of juridical reason. Manchester; Dover, N.H: Manchester University Press.

185. Simpson, Alfred William Brian. 1987. Legal theory and legal history: Essays on the common law. London; Ronceverte, W. Va.: Hambledon Press.

186. Simpson, Alfred William Brian. 1961. The ratio decidendi of a case and doctrine of precedent. In Oxford essays in jurisprudence, a collaborative work. Edited by A. G. Guest. London: Oxford University Press.

187. Simpson, Alfred William Brian. 1958. The Ratio Decidendi of a Case. Modern Law Review 21: 155-160.

188. Simpson, Alfred William Brian. 1957. The Ratio Decidendi of a Case. Modern Law Review 20: 413-415.

189. Skalak, David B., Edwina L. Rissland. 1991. Arguments and Cases: An Inevitable Intertwining. Artificial Intelligence and Law $1: 3-44$.

190. Snoek Henkemans, A. Francisca. 2000. Comments On ' Analyzing Argumentative Discourse From a Rhetorical Perspective: Defining "Person" and "Human Life" in Constitutional Debates Over Abortion'. Argumentation: An International Journal on Reasoning 14, no. 3: 333-338.

191. Soeteman, Arend. 1989. Logic in law. remarks on logic and rationality in normative reasoning, especially in law. Dordrecht: Kluwer.

192. Sowle Cahill, Lisa. 1982. Abortion and Argument by Analogy. Horizons 9: 271-287. 
116 Marcello Guarini et al.

193. Spellman, Barbara A. 2004. Reflections of a Recovering Lawyer: How Becoming a Cognitive Psychologist - and (in Particular) Studying Analogical and Causal Reasoning - Changed My Views about the Field of Psychology and Law. Chicago-Kent Law Review 79, no. 3: 1187-1214.

194. Stiegler, M. 1982. The Physician-Patient Accommodation: A Central Event in Clinical Medicine. Archives of Internal Medicine 142, no. 10: 1899-1902.

195. Stinchcombe, Arthur L. 1999. Certainty of the Law: Reasons, Situation-Types, Analogy, and Equilibrium. Journal of Political Philosophy 7, no. 3 (September): 209-224.

196. Stone, Julius. 1985. Precedent and law: Dynamics of common law growth. Sydney; Toronto: Butterworths.

197. Stone, Julius. 1964. Legal system and lawyers' reasoning. Stanford, Calif.: Stanford University Press.

198. Suber, Peter. 1988. Analogy Exercises for Teaching Legal Reasoning. Journal of Law \& Education 17, no. 1: 91-98.

199. Sullivan, Kathleen. 1992. The Supreme Court, 1991 Term -Forward: The Justice of Rules and Standards. Harvard Law Review, no. 106: 22-58.

200. Sunstein, Cass. 1996. Legal reasoning and political conflict. New York: Oxford University Press.

201. Sunstein, Cass. 1993-1994. Conflicting Values in Law. Fordham Law Review 62: 1661-1674.

202. Sunstein, Cass. 1993. On Analogical Reasoning. Harvard Law Review. 106: 741-791.

203. Sunstein, Cass. 1993. On Analogical Reasoning. Harvard Law Review 106: 741-791.

204. Susskind, Richard. 1993. Essays on law and artificial intelligence. Oslo: Tano.

205. Tammelo, Ilmar. 1969. Outlines of modern legal logic. Wiesbaden: Franz Steiner.

206. Tiscornia, Daniela. 1993. Meta-Reasoning in Law: A Computational Model. Journal of Law and Information Science 4: 368-395.

207. Tubbs, J. W. 2000. The common law mind: Medieval and early modern conceptions. Baltimore, Md.: Johns Hopkins University Press. 
208. Twining, William L., and David Miers. 1976. How to do things with rules: A primer of interpretation. London: Weidenfeld and Nicolson.

209. Ullmann-Margalit, Edna ed. 2000. Reasoning practically. New York: Oxford University Press.

210. Unger, Roberto M. 1986. The critical legal studies movement. Cambridge, Mass.: Harvard University Press.

211. Valente, André ed. 1995. Legal knowledge engineering: A modelling approach. Netherlands: IOS Press.

212. Van Buren III, Harry J. 1999. Acting More Generously than the Law Requires: The Issue of Employee Layoffs in Halakhah. Journal of Business Ethics 1, pt. 9, no. 4 (May): 335-343.

213. Vandevelde, Kenneth J. 1996. Thinking like a lawyer: An introduction to legal reasoning. Boulder, Colorado: Westview Press.

214. Verheij, Bart, Jaap Hage. 1994. Reasoning by analogy: A formal reconstruction. In Legal knowledge based systems: The relation with legal theory. Edited by H. Prakken, A. J. Muntjewerf and A. Soeteman. Lelystad: Koninklijke Vermande.

215. Wahlgren, Peter. 1992. Automation of legal reasoning: A study on artificial intelligence and law. Boston: Kluwer Academic Publishers.

216. Waldron, Jeremy. Vagueness in Law and Language: Some philosophical Issues. 1994 82: 509-517-19.

217. Wallace, Jonathan, Michael Green. 1996-1997. Bridging the Analogy Gap: The Internet, the Printing Press and Freedom of Speech. Seattle University Law Review 20: 711-748.

218. Walter, Charles ed. 1988. Computer power and legal language: The use of computational linguistics, artificial intelligence, and expert systems in the law. New York: Quorum Books.

219. Wasserstrom, Richard A. 1961. The judicial decision: Toward a theory of legal justification. Stanford, Calif.: Stanford University Press.

220. Weinreb, Lloyd L. Feb 14 2005. Legal reason: The use of analogy in legal argument. Cambridge University Press.

221. Wellman, Vincent A. 1985-1986. Practical Reasoning and Judicial Justification: Toward an Adequate Theory. University of Colorado Law Review 57: 45-116. 
118 Marcello Guarini et al.

222. Westen, Peter. 1982. On "Confusing Ideas": Reply. Yale Law Journal 91: 1153.

223. White, Gladys B. 2006. Analogical Power and Aristotle's Model of Persuasion. American Journal of Bioethics 6, no. 6: 67-68.

224. Winter, Steven L. October 2001. A clearing in the forest: Law, life, and mind. University of Chicago Press.

225. Wyner, Adam, Bench-Capon, Trevor J. M. 2007. Argument schemes for legal case-based reasoning. In Proceedings of JURIX 2007. Edited by A. Lodder and L. Mommers. IOS Press.

226. Zeleznikow, John, and Dan Hunter. 1994. Building intelligent legal information systems: Representation and reasoning in law. Deventer: Kluwer Academic Publishers.

\subsection{ETHICS OR ACTION}

1. Anderson, Elizabeth. 1993. Value in ethics and economics. Cambridge, Mass.: Harvard University Press.

2. Aristotle. 1984. Nicomachean ethics. In The complete works of Aristotle. Edited by J. Barnes. Princeton, NJ: Princeton University Press.

3. Aristotle. 1984. Politics. In The complete works of Aristotle. Edited by J. Barnes. Princeton, NJ: Princeton University Press.

4. Arras, John D. 1994. Principles and Particularity: The Roles of Cases in Bioethics. Indiana Law Journal 69, no. 4 (Fall): 9831014.

5. Beauchamp, Tom L., and James F. Childress. 1994. Principles of biomedical ethics. New York: Oxford University Press.

6. Bendik-Keymer, Jeremy. 2001. Analogical Extension and Analogical Implication in Environmental Moral Philosophy. Philosophy in the Contemporary World 8, no. 2 (Fall-Winter): 149-158.

7. Borden, Sandra L. 1999. Character As a Safeguard for Journalists Using Case-Based Ethical Reasoning. The International Journal of Applied Philosophy 13, no. 1: 93.

8. Burns, Lawrence. 2006. Banking on the Value of Analogies in Bioethics. American Journal of Bioethics 6, no. 6: 63-65.

9. Childress, James F. 1997. Practical reasoning in bioethics. Bloomington and Indianapolis: Indiana University Press. 
10. Church, Rusell T., and Charles Wilbanks. 1986. Values and policies in controversy: An introduction to argumentation and debate. Scottsdale, Arizona: Gorsuch Scarisbrick.

11. Cox, L. H. 1989. The uses of analogy in land ethics. In Freedom, equality, and social change. Edited by P. Creighton and J. Sterba P. Lewiston, NY: Mellen Press.

12. Gehl, Paul F. 2002. Moral Analogies in Print: Emblematic Thinking in the Making of Early Modern Books. Philosophica 7: 91-107.

13. Gillam, Lynn. 1997. Arguing by Analogy in the Fetal Tissue Debate. Bioethics 11, no. 5: 397-412.

14. González, García, Dora Elvira. 2001. La analogía: entre universalismo y particularismo. Rawls y Beuchot: el caso político. Revista de Filosofia 3, no. 2 (May-August): 31-50.

15. Guarini, Marcello. 2006. Particularism and the Classification and Reclassification of Moral Cases. IEEE Intelligent Systems Magazine, July/August, 22.

16. Guarini, Marcello. 2004. A Defense of Non-Deductive Reconstructions of Analogical Arguments. Informal Logic 24, no. 2: $153-168$.

17. Hofmann, Bjorn, Soren Holm, and Jan H. Solbakk. 2006. Analogical Reasoning in Handling Emerging Technologies: The Case of Umbilical Cord Blood Biobanking. American Journal of Bioethics 6, no. 6 (December): 49-57.

18. Hofmann, Bjorn, Soren Holm, and Jan H. Solbakk. 2006. Response to Open Peer Commentaries on "Analogical Reasoning in Handling Emerging Technologies: The Case of Umbilical Cord Blood Biobanking": Analogy is Like Air--Invisible and Indispensable. American Journal of Bioethics 6, no. 6 (December): W13-W14.

19. Hofmann, Bjorn, Jan H. Solbakk, and Soren Holm. 2006. Teaching Old Dogs New Tricks: The Role of Analogies in Bioethical Analysis and Argumentation Concerning New Technologies. Theoretical Medicine and Bioethics 27, no. 5 (November): 397-413.

20. Holland, Suzanne. 2006. It's not what we say, exactly... or is it? American Journal of Bioethics 6, no. 6: 65-66. 
21. Hung-yul, So. 1999. Pluralism and the moral mind. Proceedings of the Twentieth World Congress of Philosophy, Volume 1: Ethics. Bowling Green: Philosophy Documentation Center.

22. Hurley, Susan L. 1989. Natural reasons: Personality and polity. New York: Oxford University Press.

23. Jackson, Michael W. 1988. Plato's Political Analogies. International Studies in Philosophy 20: 27-42.

24. Johnson, Mark. 1993. Moral imagination: Implications of cognitive science for ethics. Chicago: University of Chicago Press.

25. Johnson, Summer, Ingrid Burger. 2006. Limitations and Justifications for Analogical Reasoning. American Journal of Bioethics 6, no. 6: 59-66.

26. Jonsen, Albert R. 1988. Transplantation of Fetal Tissue: An Ethicist's Viewpoint. Clinical Research 36: 215-219.

27. Jonsen, Albert R., and Stephen Toulmin. 1988. The abuse of casuistry: A history of moral reasoning. Berkeley: University of California Press.

28. Khong, Yuen F. 1992. Analogies at war. Princeton: Princeton University Press.

29. Loose, Donald. 2003. Burger van één wereld? Het theologischpolitieke legaat van het Kantianisme (Citizen of One World? The Theological-Political Legacy of Kantianism). Bijdragen, Tijdschrift voor Filosofie en Theologie 64: 369-399.

30. Lopez, Jose J. 2006. Mapping Metaphors and Analogies. American Journal of Bioethics 6, no. 6: 61-63.

31. Maldonado, Alejandro M. 2003. Elster, Leibniz y el espíritu del capitalismo. Laguna: Revista de Filosofia 13: 69-84.

32. May, Ernest R. 1973. "Lessons" of the past: The use and misuse of history in american foreign policy. New York: Oxford University Press.

33. McLaren, Bruce M. 2006. Computational Models of Ethical Reasoning: Challenges, Initial Steps, and Future Directions. IEEE Intelligent Systems (July/August): 29-37.

34. McLaren, Bruce M. 2003. Extensionally Defining Principles and Cases in Ethics: An AI Model. Artificial Intelligence 150, no. 1-2 (November): 145-181. 
35. Mefford, Dwain. 1990. Case-Based Reasoning, Legal Reasoning, and the Study of Politics. Political Behavior 12, no. 2, Cognition and Political Action (Jun.): 125-158.

36. Miller, Richard B. 1996. Casuistry in modern ethics: A poetics of practical reasoning. Chicago: University of Chicago Press.

37. Morphis, M., Christopher K. Riesbeck. 1990. Feminist Ethics and Case-Based Reasoning: A Marriage of Purpose. International Journal of Applied Philosophy 5, no. 2 (Fall): 15-28.

38. Musolff, Andreas. 2004. Metaphor and political discourse: Analogical reasoning in debates about europe. Basingstoke; New York: Palgrave Macmillan.

39. Neal, Karama C. 2006. Analogical Trends in Umbilical Cord Blood Legislation in the United States. American Journal of Bioethics 6, no. 6: 68-70.

40. Neustadt, Richard E., and Ernest R. May. 1986. Thinking in time: The uses of history for decision makers. New York: The Free Press.

41. Post, Stephen G., Robert G. Leisey. 1995. Analogy, Evaluation, and Moral Disagreement. Journal of Value Inquiry 29, no. 1 (March): 45-55.

42. Ramsey, Paul. 1978. Ethics at the edge of life. New Haven: Yale University Press.

43. Rawls, John. 2005. A theory of justice. Cambridge, Mass.: Belknap Press.

44. Rossouw, Gedeon J. 2003. Business Is Not Just War: Transferring the Principle of Double Effect from War to Business. South African Journal of Philosophy 22, no. 3: 236-246.

45. Samuel, Gabrielle N., Rachel A. Ankeny, and Ian Kerridge. 2006. Mixing Metaphors in Umbilical Cord Blood Transplantation. American Journal of Bioethics 6, no. 6: 58-59.

46. Scully, Jackie L. June 2001. Drawing a Line: Situating Moral Boundaries in Genetic Medicine. Bioethics 15, no. 3: 189-204.

47. Stocker, Michael. 1987. Some Problems with Counter-Examples in Ethics. Synthese: An International Journal for Epistemology, Methodology and Philosophy of Science 72 (August): 277-289.

48. Thomasma, David C. 1984. What does Medicine Contribute to Ethics? Theoretical Medicine: An International Journal for the Philosophy and Methodology of Medical Research and Practice 5 (October): 267-278. 
122 Marcello Guarini et al.

49. Thomson, Judith J., and William Parent. 1986. Rights, restitution, and risk: Essays in moral theory. Cambridge, Mass.: Harvard University Press.

50. Whaley, Bryan B. 1998. Evaluations of Rebuttal Analogy Users: Ethical and Competence Considerations. Argumentation: An International Journal on Reasoning 12, no. 3 (August): 351-365.

51. White, Jefferson. 1996. Analogical reasoning. In A companion to the philosophy of law and legal theory. Edited by D. Patterson. Oxford: Blackwell.

52. Young, Thomas. 1993. Analogical Reasoning and Easy Rescue Cases. Journal of Philosophical Research 18: 327-397.

\section{Religion OR Theology: LAnguage, logic, OR METAPHYSICS}

1. Agera, Cassian R. 2000. Religious Language As Analogical: A Study in Aquinas. Journal of Indian Council of Philosophical Research 17, no. 2 (January-April): 25-42.

2. Allen, Prudence. 1992. A Woman and a Man as Prime Analogical Beings. American Catholic Philosophical Quarterly 66, no. 4 (Autumn): 465-482.

3. Anderson, James F. 1949. The bond of being: An essay on analogy and existence. St. Louis, Missouri: B. Herder Book co.

4. Aquinas, Saint T. 1969. Summa theologiae. Garden City, N.Y.: Image Books.

5. Aquinas, Saint T. 1968. On being and essence. Toronto: Pontifical Institute of Medieval Studies.

6. Aquinas, Saint T. 1968. On the unity of the intellect against the averroists. Marquette University Press: Milwaukee.

7. Aquinas, Saint T. 1967. Liber de veritate catholicae fidei contra errores infidelium qui dicitur summa contra gentiles. Taurini: Marietti.

8. Aragüés Aldaz, José. 1999. Fronteras Estéticas de la Analogía Medieval. Revista Espanola de Filosofia Medieval 6: 157-174.

9. Ashe, Geoffrey. Meaning and Analogy. Hibbert Journal: A Quarterly Review of Religion 49: 388-393.

10. Ashworth, E. J. 2008. Medieval theories of analogy. In The Stanford encyclopedia of philosophy. Edited by E. N. Zalta. 
11. Ashworth, E. J. 2003. Language and logic. In The Cambridge companion to medieval philosophy. Edited by A. S. McGrade. Cambridge: Cambridge University Press.

12. Ashworth, E. J. 1997. Petrus fonseca on objective concepts and the analogy of being. In Logic and the workings of the mind: The logic of ideas and faculty psychology in early modern philosophy. Edited by P. A. Easton. Atascadero: Ridgeview.

13. Ashworth, E. J. 1995. Late Scholastic Philosophy: Introduction. Vivarium: An International Journal for the Philosophy and Intellectual Life of the Middle Ages and Renaissance 33, no. 1 (May): 50-75.

14. Ashworth, E. J. 1992. Analogical Concepts: The FourteenthCentury Background to Cajetan. Dialogue: Canadian Philosophical Review 31, no. 3 (Summer): 399-413.

15. Ashworth, E. J. 1992. Analogy and Equivocation in ThirteenthCentury Logic: Aquinas in Context. Mediaeval Studies 54: 94135.

16. Attfield, Robin. 1980. Religious Symbols and the Voyage of Analogy. International Journal for Philosophy of Religion 11 (Winter): 225-238.

17. Bahm, Archie J. 1944. Teleological Arguments. Scientific Monthly 58 (May): 377-382.

18. Barth, Timotheus A. 1965. Being, univocity, and analogy according to duns scotus. In John duns scotus 1265-1965 (studies in philosophy and the history of philosophy, vol. 3). Edited by J. K. Ryan and B. M. Bonansea. Washington, DC: Cath Univ of America Pr.

19. Beach, John D. 1965. Analogous Naming, Extrinsic Denomination, and the Real Order. Modern Schoolman: A Quarterly Journal of Philosophy 42 (January): 198-213.

20. Bochenski, Joseph M. 1965. The logic of religion. New York: New York University Press.

21. Bochenski, Joseph M. 1948. On Analogy. The Thomist 11: 424447.

22. Bosley, Richard N., and Martin M. Tweedale ed. 1997. Basic issues in medieval philosophy: Selected readings presenting the interactive discourses among the major figures. Peterborough, ON; Orchard Park, NY: Broadview Press. 
124 Marcello Guarini et al.

23. Burch, Robert. 1980. Bayesianism and Analogy in Hume's Dialogues. Hume Studies 6 (April): 32-44.

24. Burrell, David B. April 1962. A Note on Analogy. New Scholasticism 3, no. 6: 225-232.

25. Burrell, David B. 1985. James Ross' Portraying Analogy. New Scholasticism 59, no. 3 (Summer): 347-358.

26. Burrell, David B. 1972. Beyond the Theory of Analogy. Proceedings of the American Catholic Philosophical Association 46: 114-121.

27. Burrell, David B. 1965. John Duns Scotus: The Univocity of Analogous Terms. Monist: An International Quarterly Journal of General Philosophical Inquiry 49 (October): 639-658.

28. Cahalan, John C. 1970. Analogy and the Disrepute of Metaphysics. Thomist: A Speculative Quarterly Review 34 (July): 387-422.

29. Cajetan, Thomasso de Vio. 1962. Aristotle: On interpretation. Milwaukee: Marquette University Press.

30. Cajetan, Thomasso de Vio. 1959. The analogy of names, and the concept of being. Pittsburgh: Duquesne University.

31. Cajetan, Thomasso de Vio. 1938. Commentaria in de anima aristotelis. Romae: Institutum Angelicum.

32. Cargill, S. T. 1951. The philosophy of analogy and symbolism. London: Rider.

33. Chmielewski, Philip J. 1996. Toward an Ethics of Production: Vico and Analogy, Ricoeur and Imagination. Philosophy and Theology: Marquette University Quarterly 9, no. 3-4: 389-418.

34. Cosi, Emanuela. 2004. Analogia ed Omonimia Relativa: Aristotele e San Tommaso. Acta Philosophica: Pontificia Universita della Santa Croce 13, no. 2: 229-248.

35. Cosi, Emanuela. 2003. Le Fonti Aristoteliche della Nozione Tommasiana di Analogia: Aspetti ed applicazioni (I). Aquinas: Rivista Internazionale di Filosofia 46, no. 2-3: 365-383.

36. Cosi, Emanuela. 2003. Le Fonti Aristoteliche della Nozione Tommasiana di Analogia: Aspetti ed applicazioni (II). Aquinas: Rivista Internazionale di Filosofia 47, no. 1: 111-132.

37. Creaven, J. A. 1958. Aspects of Analogy. Philosophical Studies (Ireland) 8: 71-88.

38. Darge, Rolf. 2003. Seinswahrheit und erkenntniswahrheit: Francisco suárez und die thomistische lehre von der 'analogia 
veri'. In Miscellanea mediaevalia band 30: Die logik des Transzendentalen (festschrift für jan A. aertsen zum 65. geburtstag). Edited by M. Pickave. Berlin; New York: De Guyter.

39. De Pater, Wim A. 1995. Analogy and Disclosures: On Religious Language. Bijdragen, Tijdschrift voor Filosofie en Theologie 56, no. 3: 242-256.

40. Deely, John. 2002. The Absence of Analogy. Review of Metaphysics 55, no. 3 (March): 521-550.

41. Dilley, Frank B. 1964. Metaphysics and religious language. New York: Columbia University Press.

42. Donato, Antonio. 2003. The Role of Focus in Aquinas's Doctrine of Analogy. Proceedings of the American Catholic Philosophical Association 77: 289-301.

43. Duncan, Roger. 1980. Analogy and the Ontological Argument. New Scholasticism 54 (Winter): 25-33.

44. Duns Scotus, John. 1987. Philosophical writings. Indianapolis and Cambridge: Hackett.

45. Duns Scotus, John. 1950-. Opera omnia. Civitas Vaticana: Typis Polyglottis Vaticanis.

46. Ebert, Howard. 1993. Immutability of God: Metaphysical Inconsistency or Essential Grounding for Human Transcendence. Philosophy and Theology: Marquette University Quarterly 8, no. 1 (Autumn): 41-61.

47. Emmet, Dorothy. 1945. The nature of metaphysical thinking. London: Mamillan Company.

48. Emmet, Dorothy. 1941. The use of Analogy in Metaphysics. Proceedings of the Aristotelian Society 41: 27-46.

49. Ferguson, Sally. 2002. Bayesianism, Analogy, and Hume's Dialogues Concerning Natural Religion. Hume Studies 28, no. 1 (April): 113-130.

50. Fields, Stephen. 2003. The Singular as Event: Postmodernism, Rahner, and Balthasar. American Catholic Philosophical Quarterly 77, no. 1 (Winter): 93-111.

51. Flannery, Kevin L. 1998. Aquinas on Analogy. Gregorianum 79, no. 2: 381-384.

52. Florido, Francisco L. 2002. Ka Katholou Outos oti Prote P. Aubenque/A. de Muralt: Una Polémica Conceptual Sobre la Metafísica Aristotélica. Anales del Seminario de Historia de la Filosofia 19: 197-225. 
126 Marcello Guarini et al.

53. Foote, Edward T. 1940. Anatomy of Analogy. Modern Schoolman: A Quarterly Journal of Philosophy 18 (November): 12-16.

54. Frazer, James G. 1922. The golden bough: A study in magic and religion. New York: Macmillan.

55. Gál, Gedeon. 1996. Geraldus Odonis: On the Univocity of the Concept of Being. Franciscan Studies 52: 23-51.

56. García Díaz, Adolfo. 1999. Notes on Analogy: Aristotle, Duns Scotus (in Spanish). Revista de Filosofia (Venezuela) 31, no. 1 (January-April): 9-19.

57. Geisler, Norman L. 1991. Thomas aquinas: An evangelical appraisal. MI.: Baker Book House.

58. Gerhart, Mary, Allan M. Russell. 1990. The Cognitive Effect of Metaphor. Listening: Journal of Religion and Culture 25, no. 2 (Spring): 114-126.

59. Gill, Jerry H. 1984. Kant, Analogy, and Natural Theology. International Journal for Philosophy of Religion 16: 19-28.

60. Harris, James F. 1970. The Epistemic Status of Analogical Language. International Journal for Philosophy of Religion 1 (Winter): 211-219.

61. Harrison, Frank R. 1963. The Cajetan Tradition of Analogy. Franciscan Studies 23: 179-204.

62. Hartshorne, Charles. 1989. A dual theory of theological analogy. In God, values, and empiricism: Issues in philosophical theology. Edited by C. W. Peden and L. E. Axel. Macon, GA: Mercer University Press.

63. Hayner, Paul C. 1958. Analogical Predication. Journal of Philosophy 55 (September): 855-861.

64. Hefner, Philip. 2001. Understanding Religion: The Challenge of E. O. Wilson. Zygon: Journal of Religion and Science 36, no. 2 (June): 241-248.

65. Hemming, Laurence P. 1998. Heidegger's God. Thomist: A Speculative Quarterly Review 62, no. 3 (July): 373-418.

66. Hochschild, Joshua P. 2003. Did Aquinas Answer Cajetan's Question? Aquinas's Semantic Rules for Analogy and the Interpretation of De Nominum Analogia. Proceedings of the American Catholic Philosophical Association 77: 273-288.

67. Hume, David. 1964. Dialogues concerning natural religion. Indianapolis: Bobbs-Merrill. 
68. Ibn Taymiyya, Halim. 1993. Against the greek logicians. Oxford: Oxford University Press.

69. Jacquette, Dale. 1985. Analogical Inference in Hume's Philosophy of Religion. Faith and Philosophy: Journal of the Society of Christian Philosophers 2 (July): 287-294.

70. King-Farlow, John. 1984. Simplicity, Analogy and Plain Religious Lives. Faith and Philosophy: Journal of the Society of Christian Philosophers 1 (April): 216-229.

71. Klubertanz, George P. 1960. St Thomas aquinas on analogy: A textual analysis and systematic synthesis. Chicago: Loyola Univ Press.

72. Knasas, John F. X. 1999. The postmodern notion of freedom and aquinas's ratio entis. In The failure of modernism: The cartesian legacy and contemporary pluralism. Edited by B. Sweetman. Washington, DC: Cath Univ Amer Press.

73. Kovach, Francis. 1965. Analogy in the Fine Arts. Proceedings of the American Catholic Philosophical Association 39: 38-52.

74. Lemos, Ramon M. 1966. Anthropomorphism and Analogy. Personalist 47 (Winter-January): 112-124.

75. Lovejoy, Arthur O. 1947. Analogy and Contradiction: a Surrejoinder. Philosophy and Phenomenological Research 7 (June): 626-634.

76. Martin Soskice, Janet. 1985. Metaphor and religious language. Oxford: Oxford University Press.

77. Mavrodes, George I. 1970. On Ross's Theory of Analogy. Journal of Philosophy 67 (October): 747-754.

78. McDermott, John M. 1994. Dialectical Analogy: The Oscillating Center of Rahner's Thought. Gregorianum 75, no. 4: 675-703.

79. McInerny, Ralph. 1986. Analogy and foundationalism in Thomas aquinas. In Rationality, religious belief, and moral commitment: New essays in the philosophy of religion. Edited by $\mathrm{R}$. Audi. Ithaca: Cornell Univ Pr.

80. McInerny, Ralph. 1957. The Logic of Analogy. New Scholasticism 31 (April): 149-171.

81. McInerny, Ralph, John P. O'Callaghan. 2008. Saint Thomas aquinas. In The Stanford encyclopedia of philosophy. Edited by E. N. Zalta.

82. McPherson, Thomas. 1960. Assertion and Analogy. Proceedings of the Aristotelian Society 60: 155-170. 
128 Marcello Guarini et al.

83. Michaelson, Gordon E. 1979. The historical dimensions of a rational faith. Washington: DC University Press of America.

84. Miller, Veronica. 1973. Whitehead's God, Analogy, and Consistency of his Metaphysics. New Scholasticism 47 (Summer): 339-349.

85. Need, Stephen W. 1996. Human language and knowledge in the light of chalcedon. New York: Lang.

86. Nemetz, Anthony. 1955. The Meaning of Analogy. Franciscan Studies 15 (September): 209-223.

87. O'Callaghan, John P. 2002. Aquinas, Cognitive Theory, and Analogy: A Propos of Robert Pasnau's Theories of Cognition in the Later Middle Ages. American Catholic philosophical quarterly 76, no. 3: 451.

88. Owens, Joseph. 1962. Analogy as a Thomistic Approach to Being. Medieval Studies 24: 303-322.

89. Paley, William. 1963. Natural theology: Selections. Indianapolis: Bobbs-Merrill.

90. Palmer, Humphrey. 1973. Analogy: A study of qualification and argument in theology. London: Macmillan.

91. Phelan, Gerald B. 1941. Saint Thomas and analogy. Milwaukee: Marquette University Press.

92. Phillippe, M. D. 1969. Analogon and Analogia in the Philosophy of Aristotle. Thomist: A Speculative Quarterly Review 33 (January): 1-74.

93. Pickstock, Catherine. 2003. Modernity and Scholasticism: A Critique of Recent Invocations of Univocity. Antonianum: Periodicum Trimestre 78, no. 1 (January-March): 3-46.

94. Plantinga, Alvin. 1967. God and other minds. Ithaca, N.Y.: Cornell University Press.

95. Polansky, Ronald. 1998. Analogy and Disanalogy of the Soul's Faculties in Aristotle's De Anima. Proceedings of the Boston Area Colloquium in Ancient Philosophy 14: 57-86.

96. Porter, Andrew P. 1996. Science, Religious Language, and Analogy. Faith and Philosophy: Journal of the Society of Christian Philosophers 13, no. 1 (January): 113-120.

97. Power, William L. 1976. Musings on the Mystery of God. International Journal for Philosophy of Religion 7: 300-310.

98. Prado, C. G. 1970. A Note on Analogical Predication. New Scholasticism 44 (Fall): 603-604. 
99. Reese, William L. 1960. Analogy, Symbolism, and Linguistic Analysis. Review of Metaphysics 13 (March): 447-468.

100. Reinelt, Herbert A. 1971. A Whiteheadian Doctrine of Analogy. Modern Schoolman: A Quarterly Journal of Philosophy 48 (May): 327-342.

101. Reynolds, Philip L. 2003. Analogy of Names in Bonaventure. Mediaeval Studies 65: 117-162.

102. Reynolds, Philip L. 2003. Bonaventure's Theory of Resemblance. Traditio: Studies in Ancient and Medieval History, Thought and Religion 58: 219-255.

103. Rolls, Jonathan. October 2000. Aquinas and Analogy, by McInerny, Ralph. Heythrop Journal: A Quarterly Review of Philosophy and Theology 41, no. 4: 504-506.

104. Ross, James F. 1999. Analogy. In Oxford companion to christian thought. Edited by Anonymous Oxford; New York: Oxford University Press.

105. Ross, James F. 1970. Analogy and the Resolution of Some Cognitivity Problems. The Journal of Philosophy 67, no. 20 Sixty-Seventh Annual Meeting of the American Philosophical Association Eastern Division, Oct. 22: 725-746.

106. Ross, James F. 1970. A New Theory of Analogy. Proceedings of the American Catholic Philosophical Association 44: 70-85.

107. Ross, James F. 1961. Analogy as a Rule of Meaning for Religious Language. International Philosophical Quarterly 1 (September): 468-502.

108. Schmaltz, Tad M. 2000. The Disappearance of Analogy in Descartes, Spinoza, and Regis. Canadian Journal of Philosophy 30, no. 1 (March): 85-113.

109. Schwartz, Herbert T. 1954. Analogy in St Thomas and Cajetan. New Scholasticism 28 (April): 127-144.

110. Shannon, Daniel E. 1988. Hegel's Criticism of Analogical Procedure and the Search for Final Purpose. Owl of Minerva 19, no. 2 (Spring): 169-182.

111. Simons, Geoff. 1988. Is god a programmer? Brighton, Sussex: Harvester Press.

112. Slattery, Michael P. 1966. The Three-Fold Division of Analogy. Philosophical Studies (Ireland) 15: 131-154.

113. Slattery, Michael P. 1957. Concerning Two Recent Studies in Analogy. New Scholasticism 31 (April): 237-246. 
130 Marcello Guarini et al.

114. Slattery, Michael P. 1955. Metaphor and Metaphysics. Philosophical Studies (Ireland) 5: 89-99.

115. Stroble, Paul E. 1993. Without Running Riot: Kant, Analogical Language, and Theological Discourse. Sophia: International Journal for Philosophy of Religion, Metaphysical Theology and Ethics 32, no. 3 (November): 57-72.

116. Sweeney, Leo. 1962. Analogy and Being. Modern Schoolman: A Quarterly Journal of Philosophy 39 (March): 253-262.

117. Swinburne, Richard. 1992. Revelation: From metaphor to analogy. Oxford: Clarendon Press.

118. Thomas, John E., Ralph McInerny. 1966. Discussion: Analogy is Analogous. Laval Theologique et Philosophique 22: 73-88.

119. Tracy, David. 1987. Plurality and ambiguity: Hermeneutics, religion, hope. San Francisco: Harper \& Row.

120. Tracy, David. 1985. Analogy, Metaphor, and God-Language: Charles Hartshorne. Modern Schoolman: A Quarterly Journal of Philosophy 62 (May): 249-264.

121. Tracy, David. 1981. Analogical imagination: Christian theology and the culture of pluralism. New York: Crossroad.

122. Vaske, Martin O. 1963. An introduction to metaphysics. New york: Mcgraw Hill.

123. Webster, John. 1985. Eberhard Jungel on the Language of Faith. Modern Theology 1 (July): 253-276.

124. Wells, Harold G. 1969. Karl Barth's Doctrine of Analogy. Canadian Journal of Theology 15: 203-213.

125. Williams, Thomas. 2008. John duns scotus. In The Stanford encyclopedia of philosophy. Edited by E. N. Zalta.

126. Wong, David B. 2002. Reasons and analogical reasoning in mengzi. In Essays on the moral philosophy of mengzi. Edited by X. Liu and P. Ivanhoe J. Indianapolis: Hackett Pub.

127. Yamazaki, Tatsuya. 1997. Die Analogie als Ethisches Prinzip in der Theologie des Meister Eckhart. Freiburger Zeitschrift fuer Philosophie und Theologie 44, no. 3: 335-354.

\section{SCIENCES OR ENGINEERING}

1. Achinstein, Peter. 1972. Models and Analogies: a Reply to Girill. Philosophy of Science 39 (June): 235-240. 
2. Achinstein, Peter. 1964. Models, Analogies, and Theories. Philosophy of Science 31 (October): 328-350.

3. Achinstein, Peter. 1963. Variety and Analogy in Confirmation Theory. Philosophy of Science 30 (July): 207-221.

4. Agassi, Joseph. 1964. Analogies as Generalizations. Philosophy of Science 31 (October): 351-356.

5. Anderson, Keith M. 1969. Ethnographic Analogy and Archaeological Interpretation. Science 163, no. 3863: 133-138.

6. Aronson, Jerrold L., Rom Harre, and Eileen C. Way. 1995. Realism rescued: How scientific progress is possible. Lasalle, IL: Open Court.

7. Ascher, Robert. 1968. Time's arrow. In Settlement archeology. Edited by K. C. Chang.

8. Ascher, Robert. 1961. Analogy in Archaeological Interpretation. Southwestern Journal of Anthropology 17: 317-325.

9. Bailer-Jones, Daniela M. 2002. Models, metaphors and analogies. In Blackwell guide to the philosophy of science. Edited by $\mathrm{P}$. Machamer and M. Silberstein. Cambridge: Blackwell.

10. Bailer-Jones, Daniela M. 2000. Modelling Extended Extragalactic Radio Sources. Studies in History and Philosophy of Modern Physics 31B, no. 1 (March): 49-74.

11. Bailer-Jones, Daniela M. 1999. Creative Strategies Employed in Modelling: A Case Study. Foundations of Science 4, no. 4: 375388.

12. Baird, Davis. 1995. Meaning in a Material Medium. Proceedings of the Biennial Meetings of the Philosophy of Science Association 2: 441-451.

13. Barker, Philip. 1985. Using metaphors in psychotherapy. New York: Brunner/Mazel.

14. Bartels, Andreas. 1997. Bedeutungsketten: Ein modell der begriffsbildung in gegenwärtigen physikalischen theorien. In Analyomen 2, volume I: Logic, epistemology, philosophy of science. Edited by G. Meggle. Hawthorne: de Gruyter.

15. Beament, J. W. L. ed. 1960. Models and analogues in biology. New York: Academic Press.

16. Bhansali, Sanjay, Mehdi T. Harandi. 1993. Synthesis of UNIX Programs Using Derivational Analogy. Machine Learning 10: 755.

17. Biela, Adam. 1991. Analogy in science: From a psychological perspective. Frankfurt: Peter Lang.

18. Binford, Lewis R. 1967. Smudge Pits and Hide Smoking: The Use of Analogy in Archaeological Reasoning. American Antiquity 32, no. 1: 1-12.

19. Bolmont, Etienne. 2003. Évolution des Analogies: L'exemple de l'analogie chaleur-électricité. Philosophia Scientiae 7, no. 2: 115146. 
20. Boltzmann, Ludwig. 1911. Model. In Encyclopedia Britannica. Edited by Anonymous Cambridge: Cambridge University Press.

21. Bonner, John T. 1963. Analogies in Biology. Synthese: An International Journal for Epistemology, Methodology and Philosophy of Science 15, no. 1 (June): 275-279.

22. Bradie, Michael. 1999. Science and Metaphor. Biology and Philosophy 14, no. 2: 159-166.

23. Bradie, Michael. 1998. Models and Metaphors in Science: The Metaphorical Turn. Protosociology 12: 305-318.

24. Bradie, Michael. 1984. The Metaphorical Character of Science. Philosophia Naturalis 21: 229-243.

25. Brady, Michael E. 1987. J M Keynes' Theory of Evidential Weight: Its Relation to Information Processing Theory and Application in the General Theory. Synthese: An International Journal for Epistemology, Methodology and Philosophy of Science 71, no. 1 (April): 37-59.

26. Braithwaite, Richard B. 1962. Models in empirical science. In Logic, methodology, and philosophy of science. Edited by E. Nagel, P. Suppes and A. Tarski. Stanford University Press.

27. Braithwaite, Richard B. 1960. Scientific explanation: A study of the function of theory, probability and law in science. New York: Harper.

28. Brown, Theodore L. 2003. Making truth: Metaphor in science. Urbana: University of Illinois Press.

29. Bunge, Mario. 1969. Analogy, Simulation, Representation. Revue Internationale de Philosophie 23: 16-33.

30. Bunge, Mario. 1968. Analogy in Quantum Theory: From Insight to Nonsense. British Journal for the Philosophy of Science 18 (February): 265-286.

31. Cameron, Shelley. 2003. Multiple analogies in science and philosophy. Amsterdam: Benjamins.

32. Campbell, Lewis, and William Garnett. 1884. Life of James Clerk Maxwell. London: Macmillan.

33. Campbell, Norman R. 1920. Physics: The elements. Cambridge, England: Cambridge University Press.

34. Carloye, Jack C. 1971. An Interpretation of Scientific Models Involving Analogies. Philosophy of Science 38 (December): 562569.

35. Carnap, Rubdolf. 1963. Variety, Analogy, and Periodicity in Inductive Logic. Philosophy of Science 30 (July): 222-227.

36. Clark, Timothy. 1985. Computer as Universal Mimics. Philosophy Today 29 (Winter): 302-318.

37. Clement, John. 2008. Creative model construction in scientists and students: The role of imagery, analogy, and mental simulation. Dordrecht: Springer. 
38. Clement, John. 1993. Using Bridging Analogies in Anchoring Intuitions to Deal with Students' Preconceptions in Physics. Journal of Research in Science Teaching 30, no. 10: 1241-1257.

39. Clement, John. 1991. Non-formal reasoning in science: The use of analogies, extreme cases, and physical intuition. In Informal reasoning and education. Edited by J. Voss, D. Perkins and J. Segal. Hillsdale, NJ: Lawrence Erlbaum Associates.

40. Clement, John. 1989. Generation of spontaneous analogies by students solving science problems. In Thinking across cultures: The third international conference on thinking. Edited by D. M. Topping, D. C. Crowel and V. N. Kobayashi. Hillsdale, N.J.: Erlbaum.

41. Clement, John. 1988. Observed Methods for Generating Analogies in Scientific Problem Solving. Cognitive Science 12: 563-586.

42. Clement, John, and David Brown. 1984. Using analogical reasoning to deal with "deep" misconceptions in physics. Fund for the Improvement of Postsecondary Education.

43. Cohen, I. B. 1985. Revolution in science. Cambridge, Mass.: Harvard University Press.

44. Colby, Benjamin N. 1991. The japanese tea ceremony: Coherence theory and metaphor in social adaptation. In Beyond metaphor: The theory of tropes in anthropology. Edited by J. W. Fernandez. Stanford, Calif:: Stanford University Press.

45. Collins, James. 1957. Jaspers on science and philosophy. In The philosophy of karl jaspers. Edited by P. A. Schilpp. New York: Tudor.

46. Concetta Di Maio, Maria. 1995. Predictive Probability and Analogy by Similarity in Inductive Logic. Erkenntnis: An International Journal of Analytic Philosophy 43, no. 3 (November): 369-394.

47. Cornelis, Gustaaf C. 2000. Analogical reasoning in modern cosmological thinking. In Metaphor and analogy in the sciences. Edited by F. Hallyn. Dordrecht: Kluwer Academic Publishing.

48. Cornuéjols, Antoine, Andrée Tiberghien, and Gérard Collet. 2000. A New Mechanism for Transfer between Conceptual Domains in Scientific Discovery and Education. Foundations of Science 5, no. 2: 129-155.

49. Costantini, Domenico. 1983. Analogy by Similarity. Erkenntnis: An International Journal of Analytic Philosophy 20 (July): 103114.

50. Cragg, B. G., H. N. V. Temperley. 1955. Memory: The Analogy with Ferromagnetic Hysteresis. Brain 78, no. 2: 304-316.

51. Cragg, B. G., H. N. V. Temperley. 1954. The Organization of Neurons: A Cooperative Analogy. Electroencephalography and Clinical Neurophysiology 6, no. 1: 85-92. 
52. Craig, Braden. 1997. Behavior Combination Through Analogy. IEEE Symposium on Visual Languages : 270-273.

53. Craig, David L., Nancy J. Nersessian, and Richard Catrambone. 2002. The Role of Diagrams and Diagrammatic Affordances in Analogy. Proceedings of the Cognitive Science Society 24: 250255.

54. Cummings, Louise. 2004. Analogical Reasoning As a Tool of Epidemiological Investigation. Argumentation: An International Journal on Reasoning 1, pt. 8, no. 4: 427-444.

55. Da Costa, Newton C. A., and Steven French. 2003. Science and partial truth: A unitary approach to models and scientific reasoning. Oxford; New York: Oxford University Press.

56. Dahlbom, Bo. 1986. The role of metaphors in science. In Logic and abstraction. Edited by Anonymous Goteborg: Acta University.

57. Darden, Lindley. 2006. Reasoning in biological discoveries: Essays in mechanisms, interfield relations, and anomaly resolution. Cambridge: Cambridge University Press.

58. Darden, Lindley, Joseph A. Cain. 1989. Selection Type Theories. Philosophy of Science 56: 106-129.

59. Darwin, Charles. 1964. On the origin of species. facsimile of first edition of 1859. Cambridge, Mass.: Harvard University Press.

60. Darwin, Charles. 1958. The autobiography of Charles darwin and selected letters. New York: Dover.

61. Darwin, Charles. 1859. The origin of species. London: Murray.

62. Davies, Jim, Nancy J. Nersessian, and Ashok K. Goel. 2005. Visual Models in Analogical Problem Solving. Foundations of Science 10, no. 1: 133-152.

63. Del Re, Giuseppe. 2000. Models and Analogies in Science. Hyle: An International Journal for the Philosophy of Chemistry 6: 5-15.

64. DeMeo, Stephen. 2008. Multiple solution methods for teaching science in the classroom: Improving quantitative problem solving using dimensional analysis and proportional reasoning. Boca Raton, FL: Universal Publishers.

65. Demopoulos, William, Michael Friedman. 1985. Critical Notice: Bertrand Russell's The Analysis of Matter: Its Historical Context and Contemporary Interest. Philosophy of Science 52: 621-639.

66. Deutsch, Maury. 1987. Unification of Knowledge: a Study of Analogies. Explorations in Knowledge 4: 19-46.

67. Duhem, Pierre. 1954. The aim and structure of physical theory. Princeton New Jersey: Princeton University Press.

68. Duit, Reinders. 1991. On the Role of Analogies and Metaphors in Learning Science. Science Education 75, no. 6: 649-672.

69. Duit, Reinders, Shawn M. Glynn. 1995. Analogien--Brücken zum Verständnis. (Analogies--Bridges to understanding). Naturwissenschaften im Unterricht--Physik 27, no. 6: 4-10. 
70. Dunbar, Kevin. 2001. The analogical paradox: Why analogy is so easy in naturalistic settings, yet so difficult in the psychological laboratory. In The analogical mind. Edited by D. Gentner, K. J. Holyoak and B. N. Kokinov. Cambridge, Mass.; London, England: MIT Press/ A Bradford Book.

71. Dunbar, Kevin. 1995. How scientists really reason: Scientific reasoning in real-world laboratories. In The nature of insight. Edited by R. J. Sternberg and J. E. Davidson. Cambridge, MA: MIT Press.

72. Elio, Renee ed. 2002. Common sense, reasoning, and rationality. Oxford; New York: Oxford University Press.

73. Faden, Gerhard. 1997. Die Selbsttranszendenz der Natur. Theologie und Philosophie: Vierteljahresschrift 72, no. 3: 381394.

74. Falkenhainer, Brian. 1990. A unified approach to explanation and theory formation. In Computational models of discovery and theory formation. Edited by J. Shrager and P. Langley. San Mateo, Calif.: Morgan Kaufman.

75. Feher, Marta. 1988. The Role of Metaphor and Analogy in the Birth of the Principle of Least Action of Maupertuis (1698-1759). International Studies in the Philosophy of Science 2 (Spring): 175-188.

76. Fernandez, James W. 1991. Beyond metaphor: The theory of tropes in anthropology. Stanford, Calif.: Stanford University Press.

77. Festa, Roberto. November 1996. Analogy and Exchangeability in Predictive Inferences. Erkenntnis: An International Journal of Analytic Philosophy 45, no. 2 \& 3: 229-252.

78. Feyerabend, Paul K. 1981. Explanation, reduction and empiricism. In Realism, rationalism and scientific method. Edited by Anonymous Cambridge: Cambridge University Press.

79. Feyerabend, Paul K. 1958. An Attempt at a Realistic Interpretation of Experience. Proceedings of the Aristotelian Society 58: 143-170.

80. Feyerabend, Paul K. 1958. Complementarity, Part I. Aristotelian Society: Supplementary Volume Suppl 32: 75-104.

81. Freeman, Leslie G. 1968. A theoretical framework for interpreting archaeological materials. In Man the hunter. Edited by R. B. Lee, I. DeVore and J. Nash. Chicago: Aldine Pub. Co.

82. Frodeman, Robert. 2004. Philosophy in the field. In Rethinking nature: Essays in environmental philosophy. Edited by B. R. Foltz and R. Frodeman.

83. Gardner, Howard. 1985. The mind's new science. New York: Basic Books.

84. Gentner, Dedre. 2002. Analogy in scientific discovery: The case of johannes kepler. In Model-based reasoning: Science, 
technology, values. Edited by L. Magnani and N. J. Nersessian. New York: Kluwer Academic/ Plenum Publisher.

85. Gentner, Dedre. 1982. Are scientific analogies metaphors? In Metaphor: Problems and perspectives. Edited by D. S. Miall. Brighton, Sussex: Harvester Press Ltd.

86. Gentner, Dedre, Sarah Brem, Ronald W. Ferguson, Arthur B. Markman, Bjorn B. Levidow, Phillip Wolff, and Kenneth D. Forbus. 1997. Analogical Reasoning and Conceptual Change: A Case Study of Johannes Kepler. The Journal of the Learning Sciences 6, no. 1: 3-40.

87. Gentner, Dedre, Sarah Brem, Ronald W. Ferguson, Phillip Wolff, Arthur B. Markman, and Kenneth D. Forbus. 1997. Analogy and creativity in the works of johannes kepler. In Creative thought: An investigation of conceptual structures and processes. Edited by T. B. Ward, S. M. Smith and J. Vaid. Washington, DC: American Psychological Association.

88. Gentner, Dedre, Donald R. Gentner. 1983. Flowing waters or teeming crowds: Mental models of electricity. In Mental models. Edited by D. Gentner and A. L. Stevens. Hillsdale, N.J.: Erlbaum.

89. Gentner, Dedre, Michael Jeziorski. 1993. The shift from metaphor to analogy in western science. In Metaphor and thought. Edited by A. Ortony and C. L. Giles. England: Cambridge University Press.

90. Gentner, Dedre, Michael Jeziorski. 1989. Historical shifts in the use of analogy in science. In Psychology of science: Contributions to metascience. Edited by B. Gholson, W. R. Shadish Jr., R. A. Neimeyer and A. C. Houts. Cambridge: Cambridge University Press.

91. Gentner, Dedre, Kenneth Kurtz. 2005. Relational categories. In Categorization inside and outside the lab. Edited by A. WooKyoung, R. L. Goldstone, B. C. Love, A. B. Markman and P. Wolff. Washington, DC: APA.

92. Giere, Ronald N. 2005. Is realism dead? In Idealization XII: Correcting the model: Idealization and abstraction in the sciences (poznan studies volume 86). Edited by M. R. Jones and N. Cartwright. New York: Rodopi NY.

93. Gildenhuys, Peter. 2004. Darwin, Herschel, and the Role of Analogy in Darwin's Origin. Studies in History and Philosophy of Biological and Biomedical Sciences 35, pt. C, no. 4 (December): 593-611.

94. Girill, T. R. 1972. Analogies and Models Revisited. Philosophy of Science 39, no. 2 (June): 241-244.

95. Glynn, Shawn M. 2008. Making science concepts meaningful to students: Teaching with analogies. In Four decades of research in science education: From curriculum development to quality improvement. Edited by S. Mikelskis-Seifert, U. Ringelband and M. Bruckmann. Munster, Germany: Waxmann. 
96. Glynn, Shawn M. 2007. Methods and Strategies: The TeachingWith-Analogies Model. Science and Children 44, no. 8: 52-55.

97. Glynn, Shawn M. 2004. Connect concepts with questions and analogies. In Cases in middle and secondary science education . Edited by T. R. Koballa and D. J. Tippins. Upper Saddle River, NJ: Pearson Education.

98. Glynn, Shawn M. 2003. Teaching science concepts: Research on analogies that improve learning. In Improving science and mathematics education: Insights for a global community. Edited by D. F. Berlin and A. L. White. Columbus, Ohio: International Consortium for Research in Science and Mathematics Education.

99. Glynn, Shawn M. 1996. Teaching with Analogies: Building on the Science Textbook. The Reading Teacher 49, no. 490: 492.

100. Glynn, Shawn M. 1995. Conceptual Bridges: Using Analogies to Explain Scientific Concepts. The Science Teacher 62, no. 9: 2527.

101. Glynn, Shawn M. 1991. Explaining science concepts: A teachingwith-analogies model. In The psychology of learning science. Edited by S. M. Glynn, R. H. Yeany and B. K. Britton. Hillsdale, N.J.: Erlbaum.

102. Glynn, Shawn M. 1989. The teaching-with-analogies (TWA) model: Explaining concepts in expository text. In Children's comprehension of text: Research into practice. Edited by K. D. Muth. Newark, DE: International Reading Association.

103. Glynn, Shawn M., B. K. Britton, M. Semrud-Clikeman, and K. D. Muth. 1989. Analogical reasoning and problem solving in science textbooks. In A handbook of creativity: Assessment, theory, and research. Edited by J. A. Glover, R. R. Ronning and C. R. Reynolds. New York: Plenum.

104. Glynn, Shawn M., and Reinders Duit. 1995. Learning science in the schools: Research reforming practice. Mahwah, NJ: Erlbaum.

105. Glynn, Shawn M., Reinders Duit, and B. K. Britton. 1995. Analogies: Conceptual tools for problem solving and science instruction. In Toward a cognitive-science perspective for scientific problem solving. Edited by D. R. Lavoie. Manhattan, KS: National Association for Research in Science Teaching.

106. Glynn, Shawn M., Reinders Duit, and R. B. Thiele. 1995. Teaching science with analogies: A strategy for constructing knowledge. In Learning science in the schools: Research reforming practice. Edited by S. M. Glynn and R. Duit. Mahwah, NJ: Erlbaum.

107. Glynn, Shawn M., Gita Taasoobshirazi, and Shawn Fowler. 2007. Analogies: Explanatory Tools in Web-Based Science Instruction. Educational Technology 47, no. 5: 45-50.

108. Glynn, Shawn M., Tomone Takahashi. 1998. Learning from Analogy-Enhanced Science Text. Journal of Research in Science Teaching 35: 1129-1149. 
109. Goodman, Nelson. 1983. Fact, fiction, and forecast. Cambridge, Mass.: Harvard University Press.

110. Gould, Richard. 1980. Living archeology. Cambridge: Cambridge University Press.

111. Gould, Richard, Patty J. Watson. 1982. A Dialogue on the Meaning and use of Analogy in Ethnoarchaeological Reasoning. Journal of Anthropological Archaeology 1, no. 4 (December): 355-381.

112. Griffith, Todd W., Nancy J. Nersessian, and Ashok K. Goel. 2000. Function-follows-form transformations in scientific problem solving. In Proceedings of the Twenty-Second Annual Conference of the Cognitive Science Society: 196-201. Mahwah, New Jersey: Lawrence Erlbaum Associates.

113. Guarini, Marcello, Pierre Boulos. 2005. Problems with simplicity and analogy in ECHO and TEC. In Computing, philosophy, and cognition. Edited by L. Magnani and R. Dossena. London: College Publications.

114. Guarini, Marcello. 2003. Bohm's Metaphors, Causality, and the Quantum Potential. Erkenntnis 59: 77-95.

115. Haken, H. 1975. Analogy Between Higher Instabilities in Fluids and Lasers. Phys. Lett. A 53, no. 1: 77-78.

116. Hanson, Norwood R. 1958. Patterns of discovery: An inquiry into the conceptual foundations of science. Cambridge Eng.: University Press.

117. Harandi, Mehdi T. 1993. The Role of Analogy in Software Reuse. Symposium on Applied Computing : 40-47.

118. Harre, Rom. 1988. Where Models and Analogies really Count. International Studies in the Philosophy of Science 2 (Spring): 118-133.

119. Hatano, Giyoo, Kayoko Inagaki. 1994. Young Children's Naive Theory of Biology. Cognition 50: 171-188.

120. Hatano, Giyoo, Kayoko Inagaki. 1987. Everyday Biology and School Biology: How do they Interact? Quarterly Newsletter of the Laboratory of Comparative Human Cognition 9: 120-128.

121. Healey, Richard. 1999. Quantum Analogies: A Reply to Maudlin. Philosophy of Science 66, no. 3 (September): 440-447.

122. Hempel, Carl G. 1965. Aspects of scientific explanation, and other essays in the philosophy of science. New York: Free Press.

123. Herman, Robert A. 1900. A treatise on geometrical optics. Cambridge: Cambridge University Press.

124. Hesse, Mary. 1992. Models, metaphors and truth. Dordrecht: Kluwer.

125. Hesse, Mary. 1988. The Cognitive Claims of Metaphor. Journal of Speculative Philosophy: A Quarterly Journal of History 2, no. 1: 1-16.

126. Hesse, Mary. 1988. Theories, family resemblances and analogy. In Analogical reasoning: Perspectives of artificial intelligence, 
cognitive science, and philosophy. Edited by D. H. Helman. Dordrecht: Kluwer Academic Pub.

127. Hesse, Mary. 1987. Keynes and the Method of Analogy. Topoi: An International Review of Philosophy 6 (March): 65-74.

128. Hesse, Mary. 1974. The structure of scientific inference. Berkeley: Univresity of California Press.

129. Hesse, Mary. 1972. Models and analogy in science. In Encyclopedia of philosophy. Edited by P. Edwards. New York: Macmillan.

130. Hesse, Mary. 1966. Models and analogies in science. Notre Dame: University of Notre Dame Press.

131. Hesse, Mary. 1964. Analogy and Confirmation Theory. Philosophy of Science 3, pt. 1 (October): 319-327.

132. Hesse, Mary. 1961. Forces and fields: The concept of action at a distance in the history of physics. New York: Philosophical Library.

133. Hesse, Mary. 1953. Models in Physics. British Journal for the Philosophy of Science 4 (November): 198-214.

134. Hesse, Mary. 1952. Operational Definition and Analogy in Physical Theories. British Journal for the Philosophy of Science 2 (February): 281-294.

135. Hilpinen, Risto. 1973. Carnap's New System of Inductive Logic. Synthese: An International Journal for Epistemology, Methodology and Philosophy of Science 25 (April): 307-333.

136. Hitchcock, Christopher. 2001. A Tale of Two Effects. Philosophical Review 110, no. 3 (July): 361-396.

137. Hobbs, Jerry R. 1981. Metaphor Interpretation as Selective Inferencing. IJCAI-81 1: 85-91.

138. Hodder, Ian. 1982. The present past: An introduction to anthropology for archaeologists. Batsford, London: Cambridge University Press.

139. Hoddeson, Lillian. 2002. Toward a History-Based Model for Scientific Invention: Problem-Solving Practices in the Invention of the Transistor and the Development of the Theory of Superconductivity. Mind and Society: A Journal of Cognitive Studies in Economics and Social Sciences 3, no. 5: 67-79.

140. Horgan, James. 1994. Icon and Bild: A Note on the Analogical Structure of Models -- The Role of Models in Experiment and Theory. British Journal for the Philosophy of Science 45, no. 2 (June): 599-604.

141. Inagaki, Kayoko. 1990. The Effects of Raising Animals on Children's Biological Knowledge. British Journal of Developmental Psychology 8: 119-129.

142. Jantke, Klaus P. 1984. Program Synthesis by Analogy--A TwoPhased Approach. Artificial Intelligence: Methodology, Systems, Applications : 67-75. 
143. Kamaryt, Jan. 1995. Analogy and Homology as an Instrument of Understanding and Error. Filosoficky Casopis 43, no. 4: 565-583.

144. Kargon, Robert. 1969. Model and Analogy in Victorian Science: Maxwell and the French Physicists. Journal of the History of Ideas 30 (July-September): 423-436.

145. Kaushal, R. S. 1999. The role of structural analogy in physical sciences: A philosophical perspective. Indian Philosophical Quarterly 26, no. 4: 543.

146. Kerr, Robert. 1987. A Materialistic View of the Software "Engineering" Analogy. ACM SIGPLAN Notices 22, no. 3: 123125.

147. Klein, Sheldon, J. L. Bradshaw, Stevan Harnad, David Y. F. Ho, Bruce Holbrook, J. A. Paredes, Robert A. Rubinstein, Warren D. TenHouten, and John A. Young. 1983. Analogy and Mysticism and the Structure of Culture [and Comments and Reply]. Current anthropology 24, no. 2 (April): 151-180.

148. Kokinov, Boicho N. 2005. Can a single episode or a single story change our willingness to risk? The role of analogies in decisionmaking. In Advances in cognitive economics, proceedings of an international conference on cognitive economics. Sofia: NBU Press.

149. Kretzenbacher, Heinz L. 2003. The Aesthetics and Heuristics of Analogy: Model and Metaphor in Chemical Communication. Hyle: An International Journal for the Philosophy of Chemistry 9, no. 2: 191-218.

150. Kuhn, Thomas S. 1962. The structure of scientific revolutions. Chicago: University of Chicago Press.

151. Kuipers, Theo A. F. 1997. The Carnap-Hintikka programme in inductive logic. In Knowledge and inquiry: Essays on jaakko Hintikka's epistemology and philosophy of science. Edited by M. Sintonen. Amsterdam: Rodopi.

152. Kwiatkowski, Tadeusz. 1993. Classification of reasonings in contemporary polish philosophy. In Polish scientific philosophy: The lvov-warsaw school. Edited by C. Francesco, R. Poli and J. Wolenski. Amsterdam; Atlanta, GA: Rodopi.

153. Lafollette, Hugh, Niall Shanks. 1994. Chaos Theory: Analogical Reasoning in Biomedical Research. Idealistic Studies: An Interdisciplinary Journal of Philosophy 2, pt. 4, no. 3 (Fall): 241254.

154. Laudan, Rachel. 1982. The Role of Methodology in Lyell's Science. Studies in History and Philosophy of Science 13 (September): 215-249.

155. Leatherdale, William H. 1974. Analogy, model and metaphor in science. Amsterdam: North Holland.

156. Leatherdale, William H. 1974. The role of analogy, model, and metaphor in science. Amsterdam: North-Holland. 
157. Lee, Donald S. 1969. Analogy in Scientific Theory Construction. Southern Journal of Philosophy 7 (Summer): 107-125.

158. Lefebvre, René. 1998. Aristote Zoologue: Décrire, Comparer, Définir, Classer. Archives de Philosophie 61, no. 1 (JanuaryMarch): 33-59.

159. Leung, Harenton K. N. 2002. Estimating Maintenance Effort by Analogy. Empirical Software Engineering 7, no. 2: 157-175.

160. Little, J. 2008. The Role of Analogy in George Gamow's Derivation of Drop Energy. Technical Communication Quarterly 17: 1-19.

161. Little, J. 2000. Analogy in Science: Where Do We Go From Here? Rhetoric Society Quarterly 30: 69-92.

162. Lung, Chung-Horng, Joseph E. Urban. 1995. An Approach to the Classification of Domain Models in Support of Analogical Reuse. ACM SIGSOFT Software Engineering Notes 20, no. SI: 169-178.

163. Lynd, Helen M. 1950. The Nature of Historical Objectivity. Journal of Philosophy 47 (January): 29-42.

164. Machamer, Peter. 2000. The nature of metaphor and scientific description. In Metaphor and analogy in the sciences. Edited by F. Hallyn. Dordrecht: Kluwer Academic Publishers.

165. Maclure, Malcolm. 1988. Refutation in epidemiology: Why else not? In Causal inference. Edited by K. J. Rothman. Chesnut Hill, MA: Epidemiology Resources.

166. Magnani, Lorenzo, and Ping Li ed. 2007. Model-based reasoning in science, technology and medicine. Berlin; Heidelberg: Springer-Verlag.

167. Magnani, Lorenzo, and Nancy J. Nersessian ed. 2002. Model based reasoning: Science, technology, values. New York: Kluwer Academic/ Plenum Publishers.

168. Magnani, Lorenzo, Nancy J. Nersessian, and Claudio Pizzi ed. 2002. Logical and computational aspects of model-based reasoning. Dordrecht: Kluwer Academic Pub.

169. Magnani, Lorenzo, Nancy J. Nersessian, and Paul Thagard ed. 1999. Model-based reasoning in scientific discovery. New York: Plenum.

170. Maher, Patrick. 2004. Probability captures the logic of scientific confirmation. In Contemporary debates in philosophy of science. Edited by C. Hitchcock. Malden, MA: Blackwell.

171. Maher, Patrick. 2001. Probabilities for Multiple Properties: The Models of Hesse and Carnap and Kemeny. Erkenntnis: An International Journal of Analytic Philosophy 5, pt. 5, no. 2: 183216.

172. Margolis, Eric. 1999. What Is Glue? Minds and Machines: Journal for Artificial Intelligence 9, no. 2, pp. 241-255: May Conceptual 1999.

173. Martin, James R., Rom Harre. 1982. Metaphor in science. In Metaphor. Edited by D. S. Miall. Sussex: The Harvest Press. 
142 Marcello Guarini et al.

174. Maxwell, James C. 1890. On Faraday's lines of force. In The scientific papers of James Clerk Maxwell. Edited by W. D. Niven. New York: Dover Publications.

175. Maxwell, James C. 1881. An elementary treatise on electricity. Oxford: Clarendon Press.

176. Mellor, D. H. 1968. Models and Analogies in Science. Isis 59, no. 3: 282-290.

177. Menna, Sergio H. 2004. La Fundamentación Filosófica de los Principios No-Empíricos de Investigación. Principia: Revista Internacional de Epistemologia 8, no. 1 (June): 55-83.

178. Meynell, Hugo A. 1975. On Geese and R K Jones. Philosophy: The Journal of the Royal Institute of Philosophy 50 (January): 104-105.

179. Mickle, Marlin H. 1997. An Electrical Circuit and Computer System Analogy. The Computer Journal 40, no. 7: 457-462.

180. Morgan, Charles G. 1979. Modality, Analogy, and Ideal Experiments According to C. S. Peirce. Synthese: An International Journal for Epistemology, Methodology and Philosophy of Science 41 (May): 65-84.

181. Morgan, Mary S. 1997. The Technology of Analogical Models: Irving Fischer's Monetary Worlds. Philosophy of Science 64, no. 4: S304-S314.

182. Morrison, Margaret. 2000. Unifying scientific theories. Cambridge: Cambridge University Press.

183. Mura, Alberto. 1990. When Probabilistic Support is Inductive. Philosophy of Science 57, no. 2 (June): 278-289.

184. Murray, Tom, Klaus Schultz, David Brown, and John Clement. An Analogy-Based Computer Tutor for Remediating Science Misconceptions. Journal of Interactive Learning Environments 1, no. 2: 79-101.

185. Nagel, Ernest. 1961. The structure of science: Problems in the logic of scientific explanation. New York: Harcout, Brace \& World.

186. Nersessian, Nancy J. 2008. How science works: Model-based reasoning in scientific practice. In Scientific inquiry: Recommendations for research and implementation. Edited by $\mathrm{R}$. A. Duschl and R. E. Grandy. Rotterdam: Sense Publishers.

187. Nersessian, Nancy J. 2006. The Cognitive-Cultural Systems of the Research Laboratory. Organization Studies 27, no. 1: 125145.

188. Nersessian, Nancy J. 2006. Conceptual change: Creativity, cognition, and culture. In Models of discovery and creativity. Edited by J. Meheus and T. Nickles. Dordrecht: Kluwer Academic Publishers.

189. Nersessian, Nancy J. 2006. Model Based Reasoning in Distributed Cognitive Systems. Philosophy of Science 73.5: 699. 
190. Nersessian, Nancy J. 2005. Abstraction via generic modeling in concept formation in science. In Idealization XII: Correcting the model: Idealization and abstraction in the sciences. Edited by M. R. Jones and N. Cartwright. New York: Rodopi New York.

191. Nersessian, Nancy J. 2005. Interpreting scientific and engineering practices: Integrating the cognitive, social, and cultural dimensions. In Scientific and technological thinking. Edited by M. Gorman, R. Tweney and D. Gooding. Hillsdale, NJ: Lawrence Erlbaum.

192. Nersessian, Nancy J. 2002. The cognitive basis of model-based reasoning in science. In The cognitive basis of science. Edited by P. Carruthers, S. Stich and M. Siegal. Cambridge: Cambridge University Press.

193. Nersessian, Nancy J. 2002. Inconsistency, generic modeling, and conceptual change in science. In Inconsistency in science. Edited by J. Meheus. Dordrecht: Kluwer Academic Publishers.

194. Nersessian, Nancy J. 2002. Maxwell and 'the method of physical analogy': Model-based reasoning, generic abstraction, and conceptual change. In Reading natural philosophy: Essays in the history and philosophy of science and mathematics. Edited by D. B. Malament. Chicago: Open Court.

195. Nersessian, Nancy J. 2001. Conceptual change and commensurability. In Incommensurability and related matters. Edited by H. Sankey and P. Hoyningen-Huene. Dordrecht: Kluwer Academic Publishers.

196. Nersessian, Nancy J. 1998. Conceptual change. In A companion to cognitive science. Edited by W. Bechtel and G. Graham. Oxford: Blackwell.

197. Nersessian, Nancy J. 1996. Child's Play. Philosophy of Science 63, no. 4 (December 1996): 542-546.

198. Nersessian, Nancy J. 1995. Opening the Black Box: Cognitive Science and History of Science. Osiris 10, no. 2nd Series, Constructing Knowledge in the History of Science (1995): 194211.

199. Nersessian, Nancy J. 1995. Should Physicists Preach What They Practice? Constructive Modeling in Doing and Learning Physics. Science \& Education 4, no. 3 (July): 203-226.

200. Nersessian, Nancy J. 1992. Constructing and instructing: The role of 'abstraction techniques' in developing and teaching scientific theories. In Philosophy of science, cognitive science, \& educational theory and practice. Edited by R. A. Duschl and R. J. Hamilton. Albany: SUNY Press.

201. Nersessian, Nancy J. 1992. How do scientists think? capturing the dynamics of conceptual change in science. In Cognitive models of science. Edited by R. N. Giere. Minneapolis, MN.: University of Minnesota Press. 
202. Nersessian, Nancy J. 1991. A Method to "Meaning": A Reply to Leplin. Philosophy of Science 58, no. 4 (Dec.): 678-686.

203. Nersessian, Nancy J. 1990. Methods of Conceptual Change in Science: Imagistic and Analogical Reasoning. Philosophica 45, no. Special Issue: Scientific Discovery: 33-52.

204. Nersessian, Nancy J. 1989. Conceptual Change in Science and Science Education. Synthese (Special Issue: Philosophy of Science and Science Education) 80, no. 1: 163-184.

205. Nersessian, Nancy J. 1988. Reasoning from Imagery and Analogy in Scientific Concept Formation. PSA: Proceedings of the Biennial Meeting of the Philosophy of Science Association 1, no. 1988 Contributed papers: 41-47.

206. Nersessian, Nancy J. ed. 1987. The process of science: Contemporary philosophical approaches to understanding scientific practice. Dordrecht ; Boston: M. Nijhoff.

207. Nersessian, Nancy J. 1984. Faraday to Einstein: Constructing meaning in scientific theories. Dordrecht: Martinus Nijhoff Publishers.

208. Nersessian, Nancy J. 1982. Why is 'Incommensurability' a Problem? Acta Biotheoretica 31, no. 4 (Dec.): 205-218.

209. Niiniluoto, Ilkka. 1988. Analogy and similarity in scientific reasoning. In Analogical reasoning. Edited by D. H. Helman. Dordrecht: Kluwer Academic Publishing.

210. Niiniluoto, Ilkka. 1980. Analogy, Transitivity/the confirmation of theories. In Applications of inductive logic: Proceedings of a conference at the queen's college, 1978. Edited by L. J. Cohen and M. Hesse. Oxford: Clarendon Press.

211. North, John D. 1981. Science and analogy. In On scientific discovery: The erice lectures 1977. Edited by M. D. Grmek, R. S. Cohen and G. Cimino. Dordrecht: D. Reidel Publishing Company.

212. O'Hara, Robert J. 1996. Representations of the natural system in the nineteenth century. In Picturing knowledge: Historical and philosophical problems concerning the use of art in science. Edited by B. S. Baigrie. Toronto; Buffalo; London: Univ of Toronto Press.

213. Orme, Bryony. 1981. Anthropology for archaeologists: An introduction. Ithaca, NY: Cornell University Press.

214. Orme, Bryony. 1981. Twentieth-Century Prehistorians and the Idea of Ethnographic Parallels. Man (N.S.) 9: 481-492.

215. Orme, Bryony. 1973. Archeology and ethnography. In The explanation of culture change: Models in prehistory: Proceedings of a research seminar in archeology and related subjects held at the university of sheffield. Edited by C. Renfrew. London: Duckworth.

216. O'Rourke, Maureen. 2001. Is Virtual Trespass and Apt Analogy. Communications of the ACM 44, no. 2: 98-103. 
217. Palmer, Stephen E. 1989. Levels of description in information processing theories of analogy. In Similarity and analogical reasoning. Edited by S. Vosniadou and A. Ortony. London: Cambridge University Press.

218. Paris, Nita, Shawn M. Glynn. 2004. Elaborate Analogies in Science Text: Tools for Enhancing Preservice Teacher's Knowledge and Attitudes. Contemporary Educational Psychology 29, no. 230: 247.

219. Pask, Gordon. 1963. The use of Analogy and Parable in Cybernetics with Emphasis upon Analogies for Learning and Creativity. Dialectica: International Journal of Philosophy of Knowledge 17: 167-202.

220. Paton, Ray C. 1992. Towards a Metaphorical Biology. Biology and Philosophy 7, no. 3: 279-294.

221. Phillips, D. Z. 2000. Beyond Rules. History of the Human Sciences 13, no. 2 (May): 17-36.

222. Pietarinen, Juhani. 1972. Lawlikeness, analogy, and inductive logic. Amsterdam: North Hollandsche.

223. Radman, Zdravko ed. 1995. From a metaphorical point of view: A multidisciplinary approach to the cognitive content of metaphor. Berlin: de Gruyter.

224. Reich, K. H. 2002. Developing the horizons of the mind: Relational and contextual reasoning and the resolution of cognitive conflict. Cambridge: Cambridge University Press.

225. Roper, James E. 1982. Models and Lawlikeness. Synthese: An International Journal for Epistemology, Methodology and Philosophy of Science 52 (August): 313-323.

226. Rothbart, Daniel. 1988. Analogical information processing within scientific metaphors. In Analogical reasoning: Perspectives of artificial intelligence, cognitive science, and philosophy. Edited by D. H. Helman. Dordrecht, Holland: D. Reidel Kluwer Publishing.

227. Rothbart, Daniel. 1984. The Semantics of Metaphor and the Structure of Science. Philosophy of Science 51 (December): 595615.

228. Rumelhart, David E., and James L. McClelland ed. 1986. Parallel distributed processing: Explorations in the microstructure of cognition. Cambridge, Mass.: MIT Press.

229. Ruse, Michael. 1973. The Nature of Scientific Models: Formal "v" Material Analogy. Philosophy of the Social Sciences 3 (March): 63-80.

230. Ruse, Michael. 1973. The Value of Analogical Models in Science. Dialogue: Canadian Philosophical Review 12 (June): 246-253.

231. Salmon, Merrilee H. 1982. Philosophy and archeology. New York: Academic Press. 
232. Salmon, Merrilee H., Wesley C. Salmon. 1979. Alternative Models of Scientific Explanation. American Anthropologist 81: 61-74.

233. Schaffner, Kenneth F. 1986. Exemplar Reasoning about Biological Models and Diseases: A Relation between the Philosophy of Medicine and Philosophy of Science. Journal of Medicine and Philosophy 1, pt. 1 (February): 63-80.

234. Sellars, Wilfrid. 1965. Scientific realism or irenic instrumentalism. In Boston studies in the philosophy of science. Edited by R. S. Cohen and M. W. Wartofsky.

235. Shelley, Cameron. 2003. Multiple analogies in science and philosophy. Amsterdam: J. Benjamins.

236. Shelley, Cameron. 2002. Analogy Counterarguments and the Acceptability of Analogical Hypotheses. The British Journal for the Philosophy of Science 53, no. 4: 77-78.

237. Shelley, Cameron. 1999. Multiple Analogies in Archeology. Philosophy of Science 66, no. 4 (December): 579-605.

238. Skyrms, Brian. 1993. Analogy by similarity in HyperCarnapian inductive logic. In Philosophical problems of the internal and external worlds: Essays on the philosophy of adolf grunbaum. Edited by J. Earman, A. I. Janis, G. J. Massey and N. Rescher. Pittsburgh: University of Pittsburgh Press.

239. Smith, Adam. 1937. The wealth of nations. New York: Modern Library.

240. Smith, M. A. 1955. The Limitations of Inference in Archeology. The Archaeological Newsletter 6: 1-7.

241. Soler, Léna. 2001. Les Origines de la Formule Epsilon $=$ hv, ou Comment l'Analogie est Vecteur de Nouveauté? Philosophia Scientiae 5, no. 2: 89-123.

242. Sontag, Susan. 2001. Illness as metaphor and AIDS and its metaphors. Picador: Picador.

243. Sontag, Susan. 1979. Illness as metaphor. New York: Vintage.

244. Statile, Glenn. 1999. The Necessity of Analogy in Cartesian Science. Philosophical Forum 30, no. 3 (September): 217-232.

245. Stepan, Nancy L. 1986. Race and Gender: The Role of Analogy in Science. Isis 77: 261-277.

246. Sternberg, Robert J. 1990. Metaphors of mind. Cambridge: Cambridge University Press.

247. Sternberg, Robert J. 1977. Intelligence, information processing and analogical reasoning (the experimental psychology series). New York: John Wiley \& Sons Inc.

248. Suárez, Mauricio. 2004. An Inferential Conception of Scientific Representation. Philosophy of Science 7, pt. 1, no. 5 (December): 767-779.

249. Talalay, Lauren E. 1987. Rethinking the Function of Clay Figurine Legs From Neolithic Greece: An Argument from Analogy. American Journal of Archaeology 91: 161-169. 
250. Teller, Paul. 1998. On Huggett and Weingard's Review of An Interpretive Introduction to Quantum Field Theory: Continuing the Discussion. Philosophy of Science 65, no. 1 (March): 151161.

251. Thagard, Paul. 1997. Collaborative Knowledge. Noûs 31, no. 2 (June): 242-261.

252. Thagard, Paul. 1992. Conceptual revolutions. Princeton: Princeton University Press.

253. Thagard, Paul. 1989. Explanatory Coherence. Behavioural and Brain Sciences 12: 435-467.

254. Thagard, Paul. 1988. Computational philosophy of science. Cambridge, Mass.: MIT Press.

255. Thagard, Paul, Dawn M. Cohen, and Keith J. Holyoak. 1989. Chemical Analogies: Two Kinds of Explanation. Eleventh International Joint Conference on Artificial Intelligence : 819824.

256. Thagard, Paul, Susan Hardy. 1992. Visual Thinking in the Development of Dalton's Atomic Theory. Proceedings of the Ninth Canadian Conference on Artificial Intelligence : 30-37.

257. Thirion, Jean-Philippe. 1998. Image Matching as a Diffusion Process: An Analogy with Maxwell's Demons. Medical Image Analysis 2, no. 3: 243-260.

258. Turner, Joseph. 1956. Maxwell on the Logic of Dynamical Explanation. Philosophy of Science 36: 255.

259. Turner, Joseph. 1955. Maxwell on the Method of Physical Analogy. British Journal for the Philosophy of Science 6 (November): 226-238.

260. Umeov, A. I. 1970. The basic forms and rules of inference by analogy. In Problems in the logic of scientific knowledge. Edited by P. V. Tavenec. Dordrecht, Holland: Reidel.

261. Veloso, Manuela, and Agnar Aamodt ed. 1995. Case-based reasoning research and development: First international conference, ICCBR-95, sesimbra portugal, October 23-26, 1995, proceedings. Berlin; Heidelberg;: Springer-Verlag.

262. Vitruvius. 1960. The ten books on architecture. New York: Dover.

263. Weed, Douglas L. 1988. Causal criteria and popperian refutation. In Causal inference. Edited by K. J. Rothman. Chestnut Hill, MA: Epidemiology Res.

264. Weitzenfeld, Julian S. 1984. Valid Reasoning by Analogy. Philosophy of Science 51, no. 1 (March): 137-149.

265. Whewell, William. 1847. The philosophy of the inductive sciences, founded upon their history. London: John W. Parker.

266. Wilson, P. R. 1964. On the Argument by Analogy. Philosophy of Science 31, no. 1 (January): 34-39.

267. Wimsatt, William. 2002. Functional organization, analogy, and inference. In Functions: New essays in the philosophy of 
148 Marcello Guarini et al.

psychology and biology. Edited by A. Ariew, M. Perlman and R. Cummings. Oxford: Oxford University Press.

268. Wylie, Alison. 1988. 'Simple' Analogy and the Role of Relevance Assumptions: Implications of Archaeological Practice. International Studies in the Philosophy of Science 2 (Spring): 134-150.

269. Wylie, Alison. 1985. The Reaction against Analogy. Advances In Archaeological Method and Theory 8: 63-111. I

\section{MAThematics}

1. Bassok, Miriam. 2001. Semantic alignments in mathematical word problems. In The analogical mind. Edited by D. Gentner, K. J. Holyoak and B. N. Kokinov. Cambridge, Mass.; London, England: MIT Press/ A Bradford Book.

2. Bourbaki, Nicholas. 1950. The Architecture of Mathematics. American Mathematical Monthly 57: 221-232.

3. Bundy, Alan, David A. Basin, Dieter Hutter, and Andrew Ireland. 2005. Rippling: Meta-level guidance for mathematical reasoning. Cambridge: Cambridge University Press.

4. Cellucci, Carlo. 1998. The Scope of Logic: Deduction, Abduction, Analogy. Theoria: A Swedish Journal of Philosophy 64, no. 2-3: 217-242.

5. Colton, Simon, Alan Bundy, and Toby Walsh. 1999. Automatic Concept Formation in Pure Mathematics. Proceedings of the Sixteenth International Joint Conference on Artificial Intelligence: 786-793.

6. Colton, Simon, Anreas Meier, Volker Sorge, and Roy L. McCasland. 2004. Automatic generation of classification theorems for finite algebras. In Automated reasoning--second international joint conference. Edited by D. A. Basin and M. Rusinowitch. Berlin: Springer.

7. Corfield, David. 2003. Towards a philosophy of real mathematics. Cambridge: Cambridge University Press.

8. Corry, Leo. 1996. Modern algebra and the rise of mathematical structures. Basel: Birkhauser.

9. Da Costa, Newton C. A. 1990. Remarks on Analogy. Teoria: Rivista di Filosofia: 49-58. 
Resources for Research on Analogy 149

10. English, Lyn D. ed. 2004. Mathematical and analogical reasoning of young learners (studies in mathematical thinking and learning). Mahwah, New Jersey: Lawrence Erlbaum.

11. English, Lyn D., and Graeme S. Halford. 1995. Mathematics education: Models and processes. Hillsdale, NJ: Lawrence Erlbaum Associates.

12. English, Lyn D., Patrick V. Sharry. 1996. Analogical Reasoning and the Development of Algebraic Abstraction. Educational Studies in Mathematics 30, no. 2 (March): 135-157.

13. Evans, Thomas G. 1968. A program for the solution of a class of geometric analogy intelligence test questions. In Semantic information processing. Edited by M. Minsky. Cambridge, Mass.: MIT Press.

14. Evans, Thomas G. 1964. A Heuristic Program to Solve Geometry-Analogy Problems. Joint Computer Conference: 5-16.

15. Halmos, Paul. 1942. Finite-dimensional vector spaces. New Jersey: D. Van Nostrand.

16. Hilbert, David. 1996. Axiomatisches denken. In From kant to hilbert: A source book in mathematics. Edited by W. Ewald. Oxford: Clarendon Press.

17. Hilbert, David. 1899. Grundlagen der geometrie. Leipzig: Teubner.

18. Hochwald, Scott H. 1991. Linear Algebra by Analogy. American Mathematical Monthly 98: 918-926.

19. Kilpatrick , Jeremy, Jane Swafford, and Bradford Findell ed. 2001. Adding it up: Helping children learn mathematics. Washington, DC: National Academy Press.

20. Knobloch, Eberhard. 1989. Analogie und Mathematisches. Berichte zur Wissenschaftsgeschichte 12: 35-47.

21. Lakoff, George, and Raphael E. Núñez. 2000. Where mathematics comes from: How the embodied mind brings mathematics into being. New York: Basic Books.

22. Mancosu, Paolo, Klaus F. Jørgensen, and Stig A. Pedersen ed. 2005. Visualization, explanation and reasoning styles in mathematics. Dordrecht: Springer.

23. Maxwell, James C. 1890. Address to the mathematical and physical sections of the british association. In The scientific papers of James Clerk Maxwell. Edited by W. D. Niven. Cambridge: Cambridge University Press. 
150 Marcello Guarini et al.

24. McCune, William. 1992. Automated Discovery of New Axiomatizations of the Left Group and Right Group Calculi. Journal of Automated Reasoning 9, no. 1: 1-24.

25. McCune, William, Robert Veroff, Branden Fitelson, Kenneth Harris, Andrew Feist, and Larry Wos. 2002. Short Single Axioms for Boolean Algebra. Journal of Automated Reasoning 2, no. 1: 116.

26. Melis, Erica, Jon Whittle. 1999. Analogy in Inductive Theorem Proving. Journal of Automated Reasoning 22, no. 2: 117-147.

27. Michener, Edwina R. 1978. Understanding Understanding Mathematics. Cognitive Science 2: 361-383.

28. Novick, Laura R., Keith J. Holyoak. 1991. Mathematical Problem Solving by Analogy. Journal of Experimental Psychology: Learning, Memory and Cognition 17: 398-415.

29. Pinheiro, Ulysses. 2001. Contingência e Análise Infinita em Leibniz. Kriterion: Revista de Filosofia 42, no. 104 (JulyDecember): 72-96.

30. Polya, George. 1981. Mathematical discovery: On understanding, learning, and teaching problem solving. New York: Wiley.

31. Polya, George. 1973. Mathematics and plausible reasoning, vol. 1: Induction and analogy in mathematics. Princeton, $\mathrm{NJ}$ : Princeton University Press.

32. Polya, George. 1957. How to solve it. Princeton: University Press.

33. Polya, George, and Gabor Szego. 1976. Problems and theorems in analysis II. New York: Springer-Verlag.

34. Polya, George, and Gabor Szego. 1972. Problems and theorems in analysis $I$. New York: Springer-Verlag.

35. Poser, Hans. 1989. Vom Denken in Analogien. Berichte zur Wissenschaftsgeschichte 12: 145-157.

36. Richland, Lindsey E., Keith J. Holyoak, and James W. Stigler. 2004. Analogy Use in Eighth-Grade Mathematics Classrooms. Cognition \& Instruction 22, no. 1: 37-60.

37. Richland, Lindsey E., Osnat Zur, and Keith J. Holyoak. 2007. Cognitive Supports for Analogies in the Mathematics Classroom. Science, 1128.

38. Schlimm, Dirk. 2008. Two Ways of Analogy: Extending the Study of Analogies to Mathematical Domains. Philosophy of Science 75, no. 2: 178-200. 
39. Sternberg, Robert J. 1977. Component Processes in Analogical Reasoning. Psychological Review 84: 353-378.

40. Thomas, Robert. 2002. Mathematics and Fiction II: Analogy. Logique et Analyse 45, no. 177-178 (March-June): 185-228.

41. Thomas, Robert. 2000. Mathematics and Fiction I: Identification. Logique et Analyse 43: 301-340.

42. Ulam, Stanislaw M. 1990. Analogies between analogies: The mathematical reports of S. M. ulam and his los alamos contributors. Berkeley, CA: University of California Press.

43. van der Waerden, Bartel L. 1930. Moderne algebra. Berlin: Springer.

44. Visokolskis, Sandra. 1998. The Incidence of Analogical Procedures in the Emergence of Mathematical Concepts: Newton and Leibniz: A Case Study. Philosophica (Belgium) 62, no. 2: 91114.

45. Walther, Christoph, Thomas Kolbe. January, 2000. Proving Theorems by Reuse. Artificial Intelligence 116, no. 1-2: 17-66.

46. Wellsch, Ken, Marlene Jones. 1986. Computational Analogy. 7th European Conference on Artificial Intelligence: 93-102.

47. Wussing, Hans. 1984. The genesis of the abstract group concept. Cambridge, MA: MIT Press.

\section{Mind, Consciousness, or Cogntion}

1. Aune, Bruce. 1967. Knowledge, mind and nature. New York: Random House.

2. Bailer-Jones, Daniela M., Coryn A. L. Bailer-Jones. 2002. Modelling data: Analogies in neural networks, simulated annealing and genetic algorithms. In Model-based reasoning: Science, technology, values. Edited by L. Magnani. Dordrecht: Kluwer Academic Pub.

3. Barnes, Allison, Paul Thagard. Fall 1997. Empathy and Analogy. Dialogue: Canadian Philosophical Review 36, no. 4: 705-720.

4. Bishop, John. 1980. The Analogy Theory of Thinking. Australasian Journal of Philosophy 58 (September): 222-238.

5. Brown, Harold I. 1991. Epistemic Concepts: A Naturalistic Approach. Inquiry: An Interdisciplinary Journal of Philosophy (September): 323-351.

6. Budlong, Theodore W. 1975. Analogy, Induction and Other Minds. Analysis 35 (January): 111-112. 
152 Marcello Guarini et al.

7. Castaneda, Hector N. September 1962. Criteria, Analogy, and Knowledge of Other Minds. Journal of Philosophy 5, no. 9: 533546.

8. Cohen, John. 1957. Preconception and Analogy in Theories of the Mind. Hibbert Journal: A Quarterly Review of Religion, Theology, and Philosophy 56: 8-19.

9. Conradie, Ernst. 1992. What is an Analogical Imagination? South African Journal of Philosophy 11, no. 4 (November): 103-111.

10. Findlay, John N. 1948. Recommendations Regarding the Language of Introspection. Philosophy and Phenomenological Research 9 (December): 212-236.

11. Finke, Ronald A., Thomas B. Ward, and Steven M. Smith. 1992. Creative cognition. Cambridge, Mass.: MIT Press/Bradford Books.

12. Gentner, Dedre, Jonathan Grudin. 1985. The Evolution of Mental Metaphors in Psychology: A 90-year Retrospective. American Psychologist 40, no. 2: 181-192.

13. Goldman, Alvin. 1992. Empathy, Mind, and Morals. Proceedings and Addresses of the American Philosophical Association 66, no. 3: 17-39.

14. Haaparanta, Leila. 1992. The Analogy Theory of Thinking. Dialectica: International Journal of Philosophy of Knowledge 46, no. 2: 169-183.

15. Haney, Kathleen. 1991. Husserl's Critique of Reason. Analecta Husserliana 34: 377-397.

16. Haney, Kathleen. 1987. Response to Hutcheson's Husserl, Analogy and Other Minds. Journal of the British Society for Phenomenology 18 (October): 290-292.

17. Haney, Kathleen. 1986. A Critique of Criticism of Husserl's use of Analogy. Journal of the British Society for Phenomenology 17 (May): 143-154.

18. Heal, Jane. 2000. Inaugural Address: Other Minds, Rationality and Analogy. Supplement to the Proceedings of The Aristotelian Society 74, no. 1 (July): 1-19.

19. Hedwig, Klaus. 1982. Husserl Und Die Analogie. Zeitschrift fuer philosophische Forschung 36 (January-March): 77-86.

20. Hosiasson, Janina L. 1941. Induction et Analogie: Comparaison de leur Fondement. Mind: A Quarterly Review of Philosophy 50 (October): 351-365.

21. Hutcheson, Peter. 1987. Husserl, Analogy and Other Minds. Journal of the British Society for Phenomenology 18 (October): 285-289.

22. Hutcheson, Peter. 1987. A Rejoinder to Haney's Response to Husserl, Analogy and Other Minds. Journal of the British Society for Phenomenology 18 (October): 292.

23. Leary, David E. ed. 1990. Metaphors in the history of psychology. Cambridge: Cambridge University Press. 
24. Locke, Don. 1973. Just what is Wrong with the Argument from Analogy? Australasian Journal of Philosophy 51, no. 2 (August): 153-156.

25. Marr, David. 1982. Vision. San Francisco: Freeman.

26. Newman, M. H. A. 1928. Mr. Russell's 'Causal Theory of Perception'. Mind 37: 137-148.

27. O'Brien, Gerard. 1998. Connectionism, Analogicity and Mental Content. Acta Analytica: Philosophy and Psychology 22: 111131.

28. Olshewsky, Thomas M. 1974. The Analogical Argument for Knowledge of Other Minds Reconsidered. American Philosophical Quarterly 11 (January): 63-69.

29. Palmer, Stephen E. 1978. Fundamental aspects of cognitive representation. In Cognition and categorization. Edited by $\mathrm{E}$. Rosch and B. B. Lloyd. Hillsdale, N.J.: Erlbaum.

30. Pylkkänen, Paavo. 2004. Can quantum analogies help us to understand the process of thought? In Brain and being: At the boundary between science, philosophy, language and arts (advances in consciousness research). Edited by G. Globus G., K. H. Pribram and G. Vitiello. Amsterdam: John Benjamins Publishing co.

31. Russell, Bertrand. 1948. Human knowledge: Its scope and limits. New York: Simon \& Schuster.

32. Thagard, Paul, Cameron Shelley. 2001. Emotional analogies and analogical inference. In The analogical mind. Edited by $\mathrm{D}$. Gentner, K. J. Holyoak and B. N. Kokinov. Cambridge, Mass.; London, England: MIT Press/ A Bradford Book.

33. Van De Pitte, Frederick P. 1975. Descartes on Analogy and Other Minds. International Studies in Philosophy 7 (Fall): 89-110.

34. Vandervert, Larry R. 1991. A Measurable and Testable BrainBased Emergent Interactionism. Journal of Mind and Behavior (Spring): 201-219.

35. Zahavi, Dan. 2001. Beyond Empathy: Phenomenological Approaches to Intersubjectivity. Journal of Consciousness Studies 8, no. 5-7: 151-167.

\section{General or Wide RANGing}

\subsection{Child Development, Learning, Pedagogy, or Problem SOLVING}

1. Alma, Carine V. 1994. A Strategy for the Acquisition of ProblemSolving Expertise in Humans: The Category-as-Analogy Approach. Inquiry: Critical Thinking across the Disciplines 14, no. 2 (Winter): 17-28. 


\section{Marcello Guarini et al.}

2. Baldwin, Dare A., Ellen M. Markman, and Riikka L. Melartin. 1993. Infants' Ability to Draw Inferences About Nonobvious Object Properties: Evidence from Exploratory Play. Child Development 64: 711-728.

3. Barrow, Robin. 1997. Language: Definition and Metaphor. Studies in Philosophy and Education 16, no. 1-2 (January-April): 113-124.

4. Bassok, Miriam. 1990. Transfer of Domain-Specific ProblemSolving Proceedures. Journal of Experimental Psychology: Learning, Memory, Cognition 16: 522-533.

5. Bassok, Miriam, Keith J. Holyoak. 1993. Pragmatic knowledge and conceptual structure: Determinants of transfer between quantitative domains. In Transfer on trial: Intelligence, cognition, and instruction. Edited by D. K. Detterman and R. J. Sternberg. Norwood, N.J.: Ablex.

6. Bassok, Miriam, Keith J. Holyoak. 1989. Interdomain Transfer Between Isomorphic Topics in Algebra and Physics. Journal of Experimental Psychology: Learning, Memory, and Cognition 15: 153-166.

7. Bassok, Miriam, Ling-Ling Wu, and Karen L. Olseth. 1995. Judging a Book by its Cover: Interpretative Effects of Content on Problem Solving Transfer. Memory and Cognition 23, no. 3: 354367.

8. Bransford, John D., Jeffery J. Franks, Nancy J. Vye, and Robert D. Sherwood. 1989. New approaches to instruction: Because wisdom can't be told. In Similarity and analogical reasoning. Edited by S. Vosniadou and A. Ortony. New York: Cambridge Univeristy Pres.

9. Brown, Ann L. 1989. Analogical learning and transfer: What develops? In Similarity and analogical reasoning. Edited by S. Vosniadou and A. Ortony. Cambridge: Cambridge Univeristy Press.

10. Brown, Ann L., Mary J. Kane. 1988. Preschool Children Can Learn to Transfer: Learning to Learn and Learning from Example. Cognitive Psychology 20: 493-523.

11. Brown, Ann L., Mary J. Kane, and Catharine H. Echols. 1986. Young Children's Mental Models Determine Analogical Transfer Across Problems with a Common Goal Structure. Cognitive Development 1: 103-121. 
12. Brown, Ann L., Mary J. Kane, and Carolyn Long. 1989. Analogical Transfer in Young Children: Analogies as Tools for Communication and Exposition. Applied Cognitive Psychology 3: 275-293.

13. Burstein, Mark H. 1986. Concept formation by incremental analogical reasoning and debugging. In Machine learning: An artificial intelligence approach. Edited by R. S. Michalski, J. G. Carbonell and T. M. Mitchell. Los Altos, Calif.: Morgan Kaufman.

14. Carbonell, Jaime G. 1986. Derivational analogy: A theory of reconstructive problem solving and expertise acquisition. In Machine learning: An artificial intelligence approach. Edited by R. S. Michalski, J. G. Carbonell and T. M. Mitchell. Los Altos, Calif.: Morgan Kaufman.

15. Carbonell, Jaime G. 1983. Derivational Analogy and its Role in Problem Solving. Proceedings of the National Conference on Artificial Intelligence: 64-69.

16. Carbonell, Jaime G. 1983. Derivational Analogy in Problem Solving and Knowledge Acquisition. Proceedings of the International Machine Learning Workshop: 12-18.

17. Carbonell, Jaime G. 1983. Learning by analogy: Formulating and generalizing plans from past experience. In Machine learning: An artificial intelligence approach. Edited by R. S. Michalski, J. G. Carbonell and T. M. Mitchell. Palo Alto, Calif.: Tioga Publishing Co.

18. Carey, Susan. 1985. Conceptual change in childhood. Cambridge, Mass.: MIT Press/ Bradford Books.

19. Carpentier, Franck, Paul M. Smeets, and Dermot Barnes-Holmes. Summer 2002. Matching Functionally Same Relations: Implications for Equivalence-Equivalence as a Model for Analogical Reasoning. The Psychological Record 52, no. 3: 351371.

20. Catrambone, Richard, Keith J. Holyoak. 1989. Overcoming Contextual Limitations on Problem-Solving Transfer. Journal of Experimental Psychology: Learning, Memory, and Cognition 15: 1147-1156.

21. Clark, Andy, Annette Karmiloff-Smith. 1994. The Cognizer's Innards: A Psychological and Philosophical Perspective on the Development of Thought. Mind and Language 8: 487-568. 
156 Marcello Guarini et al.

22. Clement, John. 1998. Expert Novice Similarities and Instruction Using Analogies. International Journal of Science Education 20, no. 10: 1271-1286.

23. DeLoache, Judy S. 1989. Young Children's Understanding of the Correspondence between a Scale Model and a Larger Space. Cognitive Development 4, no. 2: 121-139.

24. DeLoache, Judy S. 1987. Rapid Change in the Symbolic Functioning of Very Young Children. Science 238: 1556-1557.

25. Duncker, Karl. 1945. On problem solving. California: American Psychological Association.

26. Duncker, Karl. 1926. A Qualitative (Experimental and Theoretical) Study of Productive Thinking (Solving of Comprehensible Problems). Journal of Genetic Psychology 33: 642-708.

27. Falkenhainer, Brian. 1987. An Examination of the Third Stage in the Analogy Process: Verification-Based Analogical Learning. Proceedings of the 10th International Joint Conference on Artificial Intelligence: 260-263.

28. Forbus, Kenneth D., Dedre Gentner. 1986. Learning physical domains: Toward a theoretical framework. In Machine learning: An artificial intelligence approach. Edited by R. S. Michalski, J. G. Carbonell and T. M. Mitchell. Los Altos, CA: Kaufmann.

29. Gelman, Rochel, Elizabeth Spelke, and E. Meck. 1983. What preschoolers know about animate and inanimate objects. In The acquisition of symbolic skills. Edited by D. Rogers and J. A. Sloboda. New York: Plenum.

30. Gentner, Dedre. 2005. The development of relational category knowledge. In Building object categories in developmental time. Edited by L. Gershkoff-Stowe and D. H. Rakinson. Hillsdale, NJ: Erlbaum.

31. Gentner, Dedre. 1992. Commentary on Halford's Theory of Cognitive Development. Human Development 35: 218-221.

32. Gentner, Dedre. 1989. The mechanisms of analogical learning. In Similarity and analogical reasoning. Edited by S. Vosniadou and A. Ortony. London: Cambridge University Press.

33. Gentner, Dedre. 1988. Metaphor as Structure Mapping: The Relational Shift. Child Development 59, no. 1: 47-59.

34. Gentner, Dedre. 1977. Children's Performance on Spatial Analogies Task. Child Development 48, no. 3: 1034-1039. 
35. Gentner, Dedre. 1977. If a Tree had a Knee, Where Would it Be? Children's Performance on Simple Spatial Metaphors. Papers and Reports on Child Language Development 13: 157-164.

36. Gentner, Dedre, Keith J. Holyoak. 1997. Reasoning and Learning by Analogy: Introduction. American Psychologist 52: 32-34.

37. Gentner, Dedre, Jeffrey Loewenstein. 2002. Learning: Analogical reasoning. In Encyclopedia of education. Edited by J. W. Guthrie. New York: Macmillian.

38. Gentner, Dedre, Jeffrey Loewenstein. 2002. Relational language and relational thought. In Language, literacy, and cognitive development. Edited by E. Amsel and J. P. Byrnes. Mahwah, N.J.: LEA.

39. Gentner, Dedre, José Medina. 1998. Similarity and the Development of Rules. Cognition 65: 263-297.

40. Gentner, Dedre, José Medina. 1998. Similarity and the development of rules. In Similarity and symbols in human thinking. Edited by S. A. Sloman and L. J. Rips. Amsterdam, the Netherlands: Elsevier Science Publishers, B.V.

41. Gentner, Dedre, Laura L. Namy. 2006. Analogical Processes in Language Learning. Current Directions in Psychological Science 15, no. 6: 297-301.

42. Gentner, Dedre, Laura L. Namy. 1999. Comparison in the Development of Categories. Cognitive Development 14: 487-513.

43. Gentner, Dedre, Mary J. Rattermann. 1998. Deep Thinking in Children: The Case for Knowledge Change in Analogical Development. Behavioral and Brain Sciences 21, no. 06: 837838.

44. Gentner, Dedre, Mary J. Rattermann. 1991. Language and the career of similarity. In Perspectives on thought and language: Interrelations in development. Edited by S. A. Gelman and J. P. Byrnes. Cambridge: Cambridge University Press.

45. Gentner, Dedre, Mary J. Rattermann, Arthur B. Markman, and Laura Kotovsky. 1995. Two forces in the development of relational similarity. In Developing cognitive competence: New approaches to process modeling. Edited by T. J. Simon and G. S. Halford. Hillsdale, NJ: LEA.

46. Gick, Mary L., Keith J. Holyoak. 1983. Schema Induction and Analogical Transfer. Cognitive Psychology 15: 1-38. 
158 Marcello Guarini et al.

47. Gick, Mary L., Keith J. Holyoak. 1980. Analogical Problem Solving. Cognitive Psychology 12: 306-355.

48. Gillespie, James J., Leigh Thompson, Jeffrey Loewenstein, and Dedre Gentner. 1999. Lessons from Analogical Reasoning in the Teaching of Negotiation. Negotiation Journal 15, no. 4: 363-371.

49. Glucksberg, Sam, Patricia Gildea, and Howard Bookin. 1982. On Understanding Nonliteral Speech: Can People Ignore Metaphors? Journal of Verbal Learning and Verbal Behaviour 21, no. 1: 8598.

50. Glynn, Shawn M., M. Law, and E. C. Doster. 1998. Making text meaningful: The role of analogies. In Learning from text across conceptual domains. Edited by C. Hynd. Mahwah, NJ: Erlbaum.

51. Goswami, Usha. 2001. Analogical reasoning in children. In The analogical mind. Edited by D. Gentner, K. J. Holyoak and B. N. Kokinov. Cambridge, Mass.; London, England: MIT Press/ A Bradford Book.

52. Goswami, Usha. 1992. Analogical reasoning in children. Hillsdale, N.J.: Erlbaum.

53. Goswami, Usha. 1991. Analogical Reasoning: What Develops? A Review of Research and Theory. Child Development 62, no. 1: 122.

54. Goswami, Usha. 1989. Relational Complexity and the Development of Analogical Reasoning. Cognitive Development 4, no. 3 (July): 251-268.

55. Goswami, Usha. Analogical reasoning in children (essays in developmental psychology). Hove: Psychology Press.

56. Goswami, Usha, Ann L. Brown. 1990. Higher-order Structure and Relational Reasoning: Contrasting Analogical and Thematic Relations. Cognition 36: 207-226.

57. Goswami, Usha, Ann L. Brown. 1989. Melting Chocolate and Melting Snowmen: Analogical Reasoning and Causal Relations. Cognition 35: 69-95.

58. Gratton, Claude. 2003. Counterexamples by Possible Conjunction and the Sufficiency of Premises. Teaching Philosophy 26, no. 1 (March): 57-81.

59. Greiner, Russell. 1988. Abstraction-based analogical inference. In Analogical reasoning: Perspectives of artificial intelligence, cognitive science, and philosophy. Edited by D. H. Helman. Dordrecht: Kluwer Academic Publishers. 
60. Greiner, Russell. 1988. Learning by Understanding Analogies. Artificial Intelligence 35, no. 1: 81-125.

61. Halasz, Frank, Thomas P. Moran. 1982. Analogy considered harmful. In Proceedings of the SIGCHI conference on human factors in computer systems. Edited by J. A. Nichols and M. L. Schneider. Association for Computing Machinery Press.

62. Halford, Graeme S. 1993. Children's understanding: The development of mental models. Hillsdale, N.J.: Erlbaum.

63. Halford, Graeme S. 1992. Analogical Reasoning and Conceptual Complexity in Cognitive Development. Human Development 35: 193-217.

64. Halford, Graeme S. 1987. A Structure-mapping Approach to Cognitive Development. International Journal of Psychology 22: 609-642.

65. Halford, Graeme S., William H. Wilson. 1980. A Category Theory Approach to Cognitive Development. Cognitive Psychology 12: 356-411.

66. Hofstadter, Douglas R. 2001. Epilogue: Analogy as the core of cognition. In The analogical mind. Edited by D. Gentner, K. J. Holyoak and B. N. Kokinov. Cambridge, Mass.; London, England: MIT Press/ A Bradford Book.

67. Holyoak, Keith J. 1985. The pragmatics of analogical transfer. In The psychology of learning and motivation. Edited by G. H. Bower. New York: Academic Press.

68. Holyoak, Keith J., Ellen N. Junn, and Dorrit O. Billman. 1984. Development of Analogical Problem-solving Skill. Child Development 55: 2042-2055.

69. Holyoak, Keith J., Paul Thagard. 1989. A computational model of analogical problem solving. In Similarity and analogical reasoning. Edited by S. Vosniadou and A. Ortony. Cambridge: Cambridge University Press.

70. Inagaki, Kayoko, Giyoo Hatano. 1987. Young Children's Spontaneous Personification as Analogy. Child Development 58: 1013-1020.

71. Inagaki, Kayoko, Kyoko Sugiyama. 1988. Attributing Human Characteristics: Developmental Changes in Over-andunderattribution. Cognitive Development 3, no. 1: 55-70.

72. Indurkhya, Bipin. 1991. On the Role of Interpretive Analogy in Learning. New Generation Computing 8, no. 4: 385-402. 
73. Jardine, David W., Morgan, G. A. V. 1987. Analogy as a Model for the Development of Representational Abilities in Children. Educational Theory 37, no. 3 (Summer): 209-217.

74. Keane, Mark T. 1996. On Adaptation in Analog: Tests of Pragmatic Importance and Adaptability in Analogical Problem Solving. The Quarterly Journal of Experimental Psychology: Learning, Memory, and Cognition 49/A, no. 4: 1062-1085.

75. Keane, Mark T. 1988. Analogical problem solving. Chichester, England; New York: Ellis Horwood; Wiley.

76. Keane, Mark T., M. Brayshaw. 1988. The incremental analogy machine: A computational model of analogy. In Proceedings of the third European working session on learning53-62. London: Pitman.

77. Keil, Frank C., W. C. Smith, Daniel J. Simons, and Daniel T. Levin. 1998. Two dogmas of conceptual empiricism: Implications for hybrid models of the structure of knowledge. In Similarity and symbols in human thinking. Edited by S. A. Sloman and L. J. Rips. Amsterdam, the Netherlands: Elsevier Science Publishers, B.V.

78. Kodratoff, Yves. 1990. Using abductive recovery of failed proofs for problem solving by analogy. In Proceedings of the 7th international conference on machine learning295-303.

79. Kolodner, Janet. 1997. Educational Implications of Analogy: A View from Case-Based Reasoning. American Psychologist 52, no. 1: 57-66.

80. Kotovsky, Laura, Dedre Gentner. 1996. Comparison and Categorization in the Development of Relational Similarity. Child Development 67, no. 6: 2797-2822.

81. Kunda, Ziva. 1990. The Case for Motivated Inference. Psychological Bulletin 108: 480-498.

82. Kurtz, Kenneth, Chun-Hui Miao, and Dedre Gentner. 2001. Learning by Analogical Bootstrapping. Journal of the Learning Sciences 10, no. 4: 417-446.

83. Loewenstein, Jeffrey, Dedre Gentner. 2005. Relational Language and the Development of Relational Mapping. Cognitive Psychology 50: 315-353.

84. Loewenstein, Jeffrey, Dedre Gentner. 2001. Spatial Mapping in Preschoolers: Close Comparisons Facilitate far Mappings. Journal of Cognition and Development 2, no. 2: 189-219. 
85. Loewenstein, Jeffrey, Leigh Thompson, and Dedre Gentner. 1999. Analogical Encoding Facilitates Knowledge Transfer in Negotiation. Psychonomic Bulletin \& Review 6, no. 4: 586-597.

86. Marks, Lawrence E., Robin J. Hammeal, and Marc H. Bornstein. 1987. Perceiving Similarity and Comprehending Metaphor. Monographs of the Society for Research in Child Development 52, no. 1: 1-102.

87. Mason, John. 2004. Teaching by Analogy: The Switch Statement. SICCSE Bulletin 36, no. 4: 105-107.

88. McKay, Thomas J. 1997. Analogy and Argument. Teaching Philosophy 20, no. 1 (March): 49-60.

89. Medin, Douglas L., Brian Ross. The specific character of abstract thought: Categorization, problem-solving and induction. In Advances in the psychology of human intelligence. Edited by R. J. Sternberg. Hillsdale, N.J.: Erlbaum.

90. Mitchell, Peter, and Kevin J. Riggs ed. 2000. Children's reasoning and the mind. Hove: Psychology Press.

91. Mutafchieva, M., Boicho N. Kokinov. 2007. Does the family analogy help young children to do relational mapping? In Proceedings of the European conference on cognitive science407412. Hillsdale, NJ: Erlbaum.

92. Namy, Laura L., Dedre Gentner. 2002. Making a Silk Purse out of Two Sow's Ears: Young Children's use of Comparison in Category Learning. Journal of Experimental Psychology 131: 515.

93. Novick, Laura R. 1988. Analogical Transfer, Problem Similarity, and Expertise. Journal of Experimental Psychology: Learning, Memory, and Cognition 14: 510-520.

94. Rattermann, Mary J., Dedre Gentner. 1998. The effect of language on similarity: The use of relational labels improves young children's performance in a mapping task. In Advances in analogy research: Integration of theory and data from the cognitive, computational, and neural sciences. Edited by K. J. Holyoak, D. Gentner and B. N. Kokinov. Sofia: New Bulgarian University Press.

95. Rattermann, Mary J., Dedre Gentner. 1998. More Evidence for a Relational Shift in the Development of Analogy: Children's Performance on a Casual-Mapping Task. Cognitive Development 13: 453-478. 


\section{Marcello Guarini et al.}

96. Riley, Thomas W., Dean A. Kowalski. 2003. Validity, Analogy, and the Holy Grail. Teaching Philosophy 26, no. 1 (March): 4356.

97. Rips, Lance J. 1975. Induction About Natural Categories. Journal of Verbal Learning and Verbal Behavior 14: 665-681.

98. Ross, Brian. 1989. Distinguishing Types of Superficial Similarities: Different Effects on the Access and Use of Earlier Problems. Journal of Expirimental Psychology: Learning, Memory, and Cognition 15, no. 3: 456-468.

99. Ross, Brian. 1987. This is Like That: The Use of Earlier Problems and the Separation of Similarity Effects. Journal of Experimental Psychology: Learning, Memory, and Cognition 13: 629-639.

100. Rumelhart, David E., Donald Norman. 1981. Analogical processes in learning. In Cognitive skills and their acquisition. Edited by J. R. Anderson. Hillsdale, N.J.: Erlbaum.

101. Schank, Roger C. 1986. Explanation patterns: Understanding mechanically and creatively. Hillsdale, N.J.: Erlbaum.

102. Schank, Roger C. 1982. Dynamic memory: A theory of reminding and learning in computers and people. New York: Cambridge University Press.

103. Schmid, Ute. 2003. Inductive synthesis of functional programs: Universal planning, folding of finite programs, and schema abstraction by analogical reasoning (lecture notes in computer science). Berlin; Heidelberg: Springer-Verlag.

104. Schumacher, Robert M., Dedre Gentner. 1988. Transfer of Training as Analogical Mapping. IEEE Transactions of Systems, Man, and Cybernetics 18: 592-600.

105. Seger, Carol A. 1994. Implicit Learning. Psychological Bulletin .

106. Seifert, Colleen M., Gail McKoon, Robert P. Abelson, and Roger Ratcliff. 1986. Memory Connections Between Thematically Similar Episodes. Journal of Experimental Psychology: Learning, Memory, and Cognition 12: 220-231.

107. Shelley, Cameron. 2004. Analogy Counterarguments: A Taxonomy for Critical Thinking. Argumentation: An International Journal on Reasoning 18, no. 2: 223-238.

108. Singer-Freeman, Karen E. 2005. Analogical Reasoning in 2-yearolds: The Development of Access and Relational Inference. Cognitive Development 20, no. 2: 214-234. 
Resources for Research on Analogy 163

109. Spellman, Barbara A., Keith J. Holyoak. 1993. An Inhibitory Mechanism for Goal-directed Analogical Mapping. Proceedings of the Fifteenth Annual Conference of the Cognitive Science Society: 947-952.

110. Spencer, R. M., Robert W. Weisberg. 1986. Context-dependent Effects on Analogical Transfer. Memory \& Cognition 14: 442449.

111. Spiro, Rand J., Paul J. Feltovich, Richard L. Coulson, and Daniel K. Anderson. 1989. Multiple analogies for complex concepts: Antidotes for analogy-induced misconception in advanced knowledge acquisition. In Similarity and analogical reasoning. Edited by S. Vosniadou and A. Ortony. Cambridge: Cambridge University Press.

112. Sternberg, Robert J., Bathsheva Rifkin. 1979. The Development of Analogical Reasoning Processes. Journal of Experimental Child Psychology 27: 195-232.

113. Thorndike, Edward L. 1913. Educational psychology. New York: Columbia University Press.

114. Treagust, David F., Reinders Duit, Paul Joslin, and Ivo Lindauer. 1992. Science Teacher's Use of Analogies: Observations from Classroom Practice. International Journal of Science Education 14: 413-422.

115. Turney, Peter D., Michael L. Littman. 2005. Corpus-Based Learning of Analogies and Semantic Relations. Machine Learning 60, no. 1-3: 251-278.

116. Turney, Peter D., Michael L. Littman. 2003. Learning Analogies and Semantic Relations. Institute for Information Technology: National Research Council.

117. Turney, Peter D., Michael L. Littman, Jeffrey Bigham, and Victor Shnayder. 2004. Combining Independent Modules in Lexical Multiple-Choice Problems. Recent Advances in Natural Language Processing III: Selected Papers from RANLP 2003: 101-110.

118. Tyrell, Donald J., Lori B. Stauffer, and Linda G. Snowman. 1991. Perception of Abstract Identity/Difference Relationships by Infants. Infant Behavior and Development 14, no. 1: 125-129.

119. Uttal, David H., Dedre Gentner, Linda L. Liu, and Alison R. Lewis. 2008. Developmental Changes in Children's 
164 Marcello Guarini et al.

Understanding of the Similarity Between Photographs and their Referents. Developmental Science 11, no. 1: 156-170.

120. van Fleet, Alanson. 1979. Learning to Teach: The Cultural Transmission Analogy. Journal of Thought 14 (November): 281290.

121. VanLehn, Kurt. 1998. Analogy Events: How Examples Are Used During Problem Solving. Cognitive Science 22, no. 3: 347-388.

122. Veloso, Manuela. 1994. Planning and learning by analogical reasoning. Berlin: Springer-Verlag.

123. Veloso, Manuela. 1993. Prodigy/ analogy: Analogical reasoning in general problem solving. In Topics on case-based reasoning, selected papers from the first European workshop on case-based reasoning. Edited by S. Wess, K. D. Altho and M. M. Richter. Berlin: Springer-Verlag.

124. Vosniadou, Stella. 1989. Analogical reasoning as a mechanism in knowledge acquisition: A development perspective. In Similarity and analogical reasoning. Edited by S. Vosniadou and A. Ortony. Cambridge: Cambridge University Press.

125. Weatherholt, Tara N., Ruby C. Harris, Barbara M. Burns, and Catherine A. Clement. 2006. Analysis of Attention and Analogical Reasoning in Children of Poverty. Journal of Applied Developmental Psychology 27, no. 2 (March-April): 125-135.

126. Winston, Patrick H. 1979. Learning and Reasoning by Analogy. Communications of the ACM 23: 689-703.

\subsection{LANGUAGE OR MetAPHySiCS}

1. Anderson, Douglas. 1984. Peirce and Metaphor. Transactions of the Charles S.Peirce Society: A Quarterly Journal in American Philosophy 20 (Fall): 453-468.

2. Anderson, James F. 1952. Some Basic Propositions Concerning Metaphysical Analogy. Review of Metaphysics 5 (March): 465472.

3. Anderson, James F. 1950. Analogy in Plato. Review of Metaphysics 4 (September): 111-128.

4. Aristotle. 1984. Metaphysics. In The complete works of Aristotle. Edited by J. Barnes. Princeton, NJ: Princeton University Press.

5. Auxier, Randall. 1997. Susanne Langer on Symbols and Analogy: A Case of Misplaced Concreteness? Process Studies 26, no. 1-2 (Spring-Summer): 86-106.

6. Beuchot, Mauricio. 2002. ¿Cómo remontar los límites del sentido? Praxis Filosofica 14 (September): 47-58. 
7. Beuchot, Mauricio. 2002. El Pensamiento Analógico en las Filosofías Analítica y Pragmática. Dianoia 47, no. 48 (May): 2536.

8. Black, Max. 1979. More about metaphor. In Metaphor and thought. Edited by A. Ortony. Cambridge: Cambridge University Press.

9. Black, Max. 1962. Models and metaphor: Studies in language and philosophy. Ithica, New York: Cornell University Press.

10. Black, Max. 1955. Metaphor. Proceedings of the Aristotelian Society 55: 273-294.

11. Blank, David. 1994. Analogy, anomaly and apollonius dyscolus. In Language. Edited by S. Everson. New York: Cambridge University Press.

12. Bogliolo, Luigi. 1980. Problemas De La Analogia. Sapientia 35: 359-372.

13. Borella, Jean. 1968. Le Zeuxis ou de L'analogie. Revue de Metaphysique et de Morale 73 (July-August): 280-293.

14. Borruso, Silvano. 2001. The Judgment, or the Awareness of the Obtained Truth. Sensus Communis: An International Quarterly for Studies and Research on Alethic Logic 2, no. 1 (JanuaryMarch): 7-16.

15. Breuvart, Jean-Marie. 1975. Prehension Whiteheadienne et Discours Philosophique. Archives de Philosophie 38 (OctoberDecember): 529-558.

16. Burke, Kenneth. 1974. The philosophy of literary form : Studies in symbolic action. Berkeley: University of California Press.

17. Burrell, David B. 1973. Analogy and philosophical language. New Haven: Yale University Press.

18. Casciano-Varin d'Ainvelle, Béatrice. 2000. La Genèse du Sens par l'Analogie. Revue Philosophique de la France et de l'Etranger 190, no. 3 (July-September): 301-318.

19. Coquand, Thierry. 1990. On the analogy between propositions and types. In Logical foundations of functional programming. Edited by G. Huet. Boston: Addison-Welsley Longman.

20. Davidson, Donald. 2001. Inquiries into truth and interpretation. Oxford; New York: Clarendon Press; Oxford University Press.

21. Davidson, Donald. 1978. What Metaphors Mean. Critical Inquiry 5: 31-47.

22. Dedina, Michael J., Howard C. Nusbaum. 1991. PRONOUNCE: A Program for Pronunciation by Analogy. Computer Speech and Language 5, no. 1: 55-64.

23. Dolan, William B. 1995. Metaphor as an Emergent Property of Machine-Readable Dictionaries. California: American Association for Artificial Intelligence.

24. Douglas, Sarah A., Thomas P. Moran. 1983. Learning Operator Semantics by Analogy. Proceedings of the National Conference on Artificial Intelligence : 100-103. 
25. Engel, S. M. 1962. Analogy and Equivocation in Hobbes. Philosophy: The Journal of the Royal Institute of Philosophy 37 (October): 326-335.

26. Ess, Charles M., Walter B. Gulick. 1994. Kant and Analogy: Categories as Analogical Equivocals. Ultimate Reality and Meaning: Interdisciplinary Studies in the Philosophy of Understanding 17, no. 2 (June): 89-99.

27. Fogelin, Robert J. 1988. Figuratively speaking. New Haven: Yale University Press.

28. García Díaz, Adolfo. 1997. In Relation to Meaning and the Synonym (in Spanish). Revista de Filosofia (Venezuela) 26-27, no. 2-3 (May-December): 221-234.

29. Gay, William. 1980. Analogy and Metaphor: Two Models of Linguistic Creativity. Philosophy and Social Criticism 7 (FallWinter): 299-317.

30. Gentner, Dedre. 2003. Why we're so smart. In Language in mind: Advances in the study of language and thought. Edited by D. Gentner and S. Goldin-Meadow. Cambridge, MA: MIT Press.

31. Gentner, Dedre, Brian F. Bowdle. 2001. Convention, Form, and Figurative Language Processing. Metaphor and Symbol 16, no. 3 \& 4: 223-247.

32. Gentner, Dedre, Brian F. Bowdle, Phillip Wolff, and Consuelo Boronat. 2001. Metaphor is like analogy. In The analogical mind: Perspectives from cognitive science. Edited by D. Gentner, K. J. Holyoak and B. N. Kokinov. Cambridge, MA: MIT Press.

33. Gentner, Dedre, Catherine A. Clement. 1988. Evidence for relational selectivity in the interpretation of analogy and metaphor. In The psychology of learning and motivation: Advances in research and theory. Edited by G. H. Bower. New York: Academic Press.

34. Gentner, Dedre, Brian Falkenhainer, and Janice Skorstad. 1988. Viewing metaphor as analogy. In Analogical reasoning. Edited by D. H. Helman. Dordrecht: Kluwer Academic Publisher.

35. Gentner, Dedre, Ilene M. France. 1988. The verb mutability effect: Studies of the combinatorial semantics of nouns and verbs. In Lexical ambiguity resolution in the comprehension of human language. Edited by S. L. Small, G. W. Cottrell and M. K. Tanenhaus. Los Altos, Calif.: Morgan Kaufman.

36. Gentner, Dedre, and Susan Goldin-Meadow ed. 2003. Language in mind: Advances in the study of language and thought. Cambridge, MA: MIT Press.

37. Gentner, Dedre, Mutsumi Imai, and Lera Boroditsky. 2002. As Time Goes By: Evidence for Two Systems in Processing SpaceTime Metaphors. Language and Cognitive Processes : 537-565.

38. Gentner, Dedre, Arthur B. Markman. 1995. Similarity is like analogy: Structural alignment in comparison. In Similarity in 
language, thought and perception. Edited by C. Cacciari. Brussels: Brepols.

39. Gentner, Dedre, José Medina. 1997. Comparison and the Development of Cognition and Language. Cognitive Studies: Bulletin of the Japanese Cognitive Science Society 4, no. 1: 112149.

40. Gentner, Dedre, Cecile Toupin. 1986. Systematicity and Surface Similarity in the Development of Analogy. Cognitive Science 10: 277-300.

41. Gentner, Dedre, Phillip Wolff. 2000. Metaphor and knowledge change. In Cognitive dynamics: Conceptual change in humans and machines. Edited by A. B. Markman and E. Dietrich. Mahwah, N.J.: Erlbaum.

42. George, Rolf. 2003. Van Cleve and Kant's Analogies. Philosophy and Phenomenological Research 66, no. 1 (January): 203-210.

43. Gibbs, Raymond W. 2001. Figurative language. In The MIT encyclopedia of the cognitive sciences. Edited by R. A. Wilson and F. C. Keil. Cambridge, MA: MIT Press.

44. Girju, Roxana, Preslav Nakov, Vivi Nastase, Stan Szpakowicz, Peter D. Turney, and Deniz Yuret. 2007. SemEval-2007 Task 04: Classification of Semantic Relations Between Nominals. Proceedings of the Fourth International Workshop on Semantic Evaluations : 13-18.

45. Glouberman, Mark. 1975. Space and Analogy. Mind: A Quarterly Review of Philosophy 84 (July): 355-373.

46. Glucksberg, Sam, Boaz Keysar. 1990. Understanding Metaphorical Comparisons: Beyond Similarity. Psychological Review 97: 3-18.

47. Goodman, Nelson. 1978. Ways of worldmaking. Indianapolis: Hackett Pub. Co.

48. Goodman, Nelson. 1972. Problems and projects. Indianapolis: Bobbs-Merrill.

49. Goodman, Nelson. 1968. Languages of art: An approach to a theory of symbols. Indianapolis: Bobbs-Merrill.

50. Grünfeld, Joseph. 2003. Analogical and Metaphorical Reasoning. Prima Philosophia 16, no. 3 (July-September): 311-322.

51. Gupta, Anoop K. 1998. Defending Metaphysical Realism from Putnam: Hermeneutics and Argument by Analogy. De Philosophia 14, no. 2 (Fall-Winter): 287-298.

52. Harding, Anthony J. 2000. Coleridge, Natural History, and the 'Analogy of Being'. History of European Ideas 26, no. 3-4: 143158.

53. Harre, Rom. 1989. Realism, reference and theory. In Key themes in philosophy. Edited by A. P. Griffiths. Cambridge, UK: Cambridge University Press.

54. Harre, Rom. 1960. Metaphor, Model and Mechanism. Proceedings of the Aristotelian Society 60: 101-122. 
Marcello Guarini et al.

55. Hausman, Carl R. 1988. Fourthness: Carl Vaught on Peirce's Categories. Transactions of the Charles S.Peirce Society: A Quarterly Journal in American Philosophy 24 (Spring): 265-277.

56. Helman, David H. 1986. Situation Semantics and Models of Analogy. Philosophical Studies: An International Journal for Philosophy in the Analytic Tradition 4, pt. 9 (March): 231-244.

57. Henle, Paul. 1958. Metaphor. In Language, thought and culture. Edited by P. Henle. Ann Arbor, Michigan: University of Michigan Press.

58. Hernández, Miguel. 1998. El Legado Morfólogico de Descartes y Vico. Cuadernos Sobre Vico 9/10: 243-258.

59. Hodder, Ian. 1982. Symbols in action: Ethnoarchaeological studies of material culture. Cambridge: Cambridge University Press.

60. Holyoak, Keith J. 1982. An Analogical Framework for Literary Interpretation. Poetics 11: 105-126.

61. Itkonen, Esa. 2005. Analogy as structure and process. Amsterdam; Philadelphia: John Benjamins Publishing Company.

62. Itkonen, Esa. 1994. Iconicity, Analogy, and Universal Grammar. Journal of Pragmatics 2, pt. 2, no. 1 (July): 37-53.

63. Jones, Royce. 1974. Plato's Analogy of Beauty. Midwestern Journal of Philosophy (Spring): 13-21.

64. Kant, Immanuel. 1929. Critique of Pure Reason. Translated by Norman Kemp Smith. London: MacMillan Press.

65. Kaplan, Roger J. 1995. Derivational Processes: Underlying Forms and Analogies in Hayyûj's Linguistic Works. AJS Review 20, no. 2: 313-332.

66. Karpatschof, Benny. 1982. Artificial Intelligence or Artificial Signification? Journal of Pragmatics 6 (August): 293-304.

67. Kittay, Eva F. 1987. Metaphor: Its cognitive force and linguistic structure. Oxford: Clarendon Press.

68. Lakoff, George. 1994. What is metaphor? In Analogy, metaphor, and reminding. Edited by J. A. Barnden and K. J. Holyoak. Norwood, N.J.: Ablex.

69. Lakoff, George. 1993. The contemporary theory of metaphor. In Metaphor and thought. Edited by A. Ortony. Cambridge: Cambridge University Press.

70. Lakoff, George. 1990. Women, fire, and dangerous things: What categories reveal about the mind. Chicago: University of Chicago Press.

71. Lakoff, George, and Mark Johnson. 2000. Philosophy in the flesh: The embodied mind and its challenge to western thought. New York: Basic Books.

72. Lakoff, George, and Mark Johnson. 1980. Metaphors we live by. Chicago: Univ. of Chicago Press. 
73. Lakoff, George, and Mark Turner. 1989. More than cool reason: A field guide to poetic metaphor. Chicago: University of Chicago Press.

74. Langacker, Ronald W. 1987. Foundations of cognitive grammar. Stanford: Stanford University Press.

75. Lassaline, Mary E. 1996. Structural Alignment in Induction and Similarity. Journal of Experimental Psychology: Learning, Memory, and Cognition 23, no. 4: 946-967.

76. Levinson, Stephen C. 1983. Pragmatics. Cambridge Cambridgeshire; New York: Cambridge University Press.

77. Lichter, Tilman. 1995. Bill Clinton is the First Lady of the USA: Making and Unmaking Analogies. Synthese: An International Journal for Epistemology, Methodology and Philosophy of Science 104, no. 2 (August): 285-297.

78. Liu, Shu-Hsien. 1974. The use of Analogy and Symbolism in Traditional Chinese Philosophy. Journal of Chinese Philosophy 1 (June-September): 313-338.

79. López-Farjeat, Luis X. 2004. Analogía Poética de Alfarabi. Revista Espanola de Filosofia Medieval 1, pt. 1: 257-272.

80. Lütterfelds, Wilhelm. 2004. Analogie und proportion: Über Platons und Hegels dialektikverständnis. In Glauben und wissen, zweiter teil (hegel-jahrbuch 2004). Edited by A. Arndt, K. Bal, H. Ottman and W. R. Beyer. Berlin: Akademie Verlag.

81. Macdonald, Margaret. 1951-1953. The philosopher's use of analogy in logic and language. In Logic \& language. Edited by A. G. N. Flew. Oxford: Blackwell.

82. Macdonald, Margaret. 1937-1938. The philosopher's use of analogy. In Proceedings of the aristotelian society.

83. Mackie, John L. 1972. Fallacies. In The encyclopedia of philosophy, volume three. Edited by P. Edwards. Macmillan Publishing.

84. Malone, Joseph L. 1969. Rules of Synchronic Analogy: a Proposal Based on Evidence from Three Semitic Languages. Foundations of Language 5 (November): 534-559.

85. Markman, Arthur B., Dedre Gentner. 2001. Thinking. Annual Review of Psychology 52, no. 1: 223-247.

86. Martin, James H. 1994. Metabank: A Knowledge-Base of Metaphoric Language Conventions. Computational Intelligence 10, no. 2: 134-149.

87. McCloskey, Mary A. 1964. Metaphors. Mind: A Quarterly Review of Philosophy 73 (April): 215-233.

88. McKellin, William H. 1995. Hidden paths in the forest: Distributed culture, communication, and cognition among the managalese of papua new guinea. Toronto: Toronto University Press.

89. McKellin, William H. 1990. Allegory and inference: Intentional ambiguity in managalese negotiations. In Disentangling: Conflict 
discourse in pacific societies. Edited by K. A. Watson-Gegeo and G. M. White. Stanford, Calif.: Stanford University Press.

90. McKellin, William H. 1984. Putting down roots: Information in the language of managalese exchange. In Dangerous words: Language and politics in the pacific. Edited by D. Brenneis and F. Myers. New York: New York University Press.

91. McNabb, Darin. 2001. Peirce y la Hermenéutica Analógica de Mauricio Beuchot. Analogia Filosofica: Revista de Filosofia 1, pt. 5, no. 2 (July-December): 157-169.

92. Melchiorre, Virgilio. 1993. L'analogia in Aristotele. Rivista di Filosofia Neo-Scolastica 85, no. 2-4 (April-December): 230-255.

93. Miller, George A., Richard Beckwith, Christiane Fellbaum, Derek Gross, and Katherine Miller. 1990. Introduction to WordNet: An On-line Lexical Database. International Journal of Lexicography 3: 235-244.

94. Moutsopoulos, Evanghélos. 2004. Desmos Kallistos Kairios: Sur la Dynamique de l'Idée d'Analogie chez Proclus. Philosophia: Yearbook of the Research Center for Greek Philosophy at the Academy of Athens 3, pt. 4: 277-279.

95. Mutafchieva, M., Boicho N. Kokinov. 2007. Can language be replaced? physical representations of relations instead of language labels in relational mapping: Do they help young children? In Proceedings of the 29th annual conference of the cognitive science society. Hillsdale, NJ: Erlbaum.

96. Myers, Charles M. 1962. Inexplicable Analogies. Philosophy and Phenomenological Research 22 (March): 326-333.

97. Novick, Laura R. 1988. Analogical transfer: Processes and individual differences. In Analogical reasoning: Perspectives of artificial intelligence, cognitive science, and philosophy. Edited by D. H. Helman. Dordrecht: Kluwer Academic Pub.

98. Olshewsky, Thomas M. 1968. Aristotle's use of Analogia. Apeiron: A Journal for Ancient Philosophy and Science 2 (July): $1-10$.

99. Ortony, Andrew ed. 1993. Metaphor and thought. New York: Cambridge University Press.

100. Ortony, Andrew. 1979. Beyond Literal Similarity. Psychological Review 87: 161-180.

101. Pears, David. 1993. The Ego and the Eye: Wittgenstein's Use of an Analogy. Grazer Philosophische Studien 44: 59-68.

102. Peterson, John. 1979. 'True' as Analogical. New Scholasticism 53 (Winter): 86-95.

103. Preus, Anthony. 1970. The Continuous Analogy. Agora: A Journal of the Humanities and the Social Sciences 1 (Spring): 2142.

104. Putnam, Hilary. 1987. The many faces of realism. La Salle, Ill.: Open Court. 
105. Rapp, Christof. 1992. Ahnlichkeit, Analogie und Homonymie bei Aristoteles. Zeitschrift fuer philosophische Forschung 46, no. 4 (October-December): 526-544.

106. Rickheit, Gert, and Christopher Habel ed. 1999. Mental models in discourse processing and reasoning. Amsterdam: Elsevier Science.

107. Ricoeur, Paul. 1985. Time and narrative. Chicago: University of Chicago Press.

108. Saavedra Ramírez, Gabriel. 2000. The Analogical Hermeneutics of Mauricio Beuchot (in Spanish). Revista de Filosofia (Venezuela) 35, no. 2 (May-August): 23-40.

109. Saha, P. K. 1988. Metaphorical style as message. In Analogical reasoning: Perspective of artificial intelligence, cognitive science and philosophy. Edited by D. H. Helman. Dordrecht: Kluwer Academic Publishers.

110. Scheffler, Israel. 1979. Beyond the letter : A philosophical inquiry into ambiguity, vagueness, and metaphor in language. London ; Boston: Routledge \& Kegan Paul.

111. Searle, John R. 1979. Expression and meaning. Cambridge: Cambridge University Press.

112. Sembugamoorthy, Vel. 1981. Analogy-Based Acquisition of Utterances Relating to Temporal Aspects. IJCAI-81 1: 106-108.

113. Simhony, Avital. 1991. Idealist Organicism: Beyond Holism and Individualism. History of Political Thought 12, no. 3 (Fall): 515535.

114. Simon, Yves R. 1960. On Order in Analogical Sets. New Scholasticism 34 (January): 1-42.

115. Sklar, Lawrence. 1980. Semantic Analogy. Philosophical Studies: An International Journal for Philosophy in the Analytic Tradition 38 (October): 217-234.

116. Sperber, Dan, and Deirdre Wilson. 2001. Relevance: Communication and cognition. Oxford ; Cambridge, MA: Blackwell Publishers.

117. Steinhart, Eric C. 2001. The logic of metaphor: Analogous parts of possible worlds. Dordrecht: Kluwer Academic Publishers.

118. Stern, Josef. 2001. Knowledge by Metaphor. Midwest Studies in Philosophy 25: 187-226.

119. Stetter, Christian. 1979. Peirce und Saussure. Kodikas/Code: An International Journal of Semiotics 1 (April): 124-149.

120. Stewart, M. A. 1980. Locke's Mental Atomism and the Classification of Ideas: II. Locke Newsletter: An Annual Journal of Locke Research 11 (Autumn): 25-62.

121. Sweet, Albert M. 1963. A Semantic Explication of Metaphysical Analogy. Philosophy and Phenomenological Research 23 (June): 595-604. 
122. Syrovatka, Jiri. 2000. Analogy and Understanding: Czech and Slovak Papers on Semiotics and Communication = Analogie et Compréhension. Theoria 15, no. 39: 435-450.

123. Thein, Karel. 1998. La Décision de l'Analogie: Remarque sur Derrida, Lecteur de Platon. Revue Internationale de Philosophie 52, no. 205 (October): 377-396.

124. Tirrell, Lynne. 1991. Reductive and Nonreductive Simile Theories of Metaphor. Journal of Philosophy 88: 337-358.

125. Traversa, Guido. 2001. Dalla Forma Logica alla Rappresentazione Perspicua: Lettera a Marco Mazzeo su Ludwig Wittgenstein. Il Cannocchiale: Rivista di Studi Filosofici 3 (September-December): 225-231.

126. Turner, Mark. 1988. Categories and analogies. In Analogical reasoning. Edited by D. H. Helman. Dordrecht: Kluwer Academic Pub.

127. Turner, Mark. 1987. Death is the mother of beauty: Mind, metaphor, criticism. Chicago: University of Chicago Press.

128. Turney, Peter D. 2008. A Uniform Approach to Analogies, Synonyms, Antonyms, and Associations. Proceedings of the 22nd International Conference on Computational Linguistics : 905912.

129. Turney, Peter D. 2006. Expressing Implicit Semantic Relations Without Supervision. Proceedings the 21st International Conference on Computational Linguistics and 44th Annual Meeting of the Association for Computational Linguistics : 313320.

130. Turney, Peter D. 2006. Similarity of Semantic Relations. Computational Linguistics 32, no. 3: 379-416.

131. Turney, Peter D. 2005. Measuring Semantic Similarity by Latent Relational Analysis. Proceedings of the Nineteenth International Joint Conference on Artificial Intelligence : 1136-1141.

132. Turney, Peter D. 2004. Human-Level Performance on Word Analogy Questions by Latent Relational Analysis. Institute for Information Technology: National Research Council.

133. Tweney, Ryan D. 1979. Reflections on the History of Behavioral Theories of Language. Behaviorism 7 (Spring): 91-103.

134. van Dormael, Jan. 1992. Analogical Reasoning: A Logical Inquiry About Archaic Thought. Communication and Cognition: An Interdisciplinary Quarterly Journal 2, pt. 5, no. 2-3: 243-258.

135. Vaught, Carl G. 1987. Metaphor, analogy, and the nature of truth. In New essays in metaphysics. Edited by R. C. Neville. Albany: Suny Press.

136. Vaught, Carl G. 1986. Semiotics and the Problem of Analogy: A Critique of Peirce's Theory of Categories. Transactions of the Charles S.Peirce Society: A Quarterly Journal in American Philosophy 22 (Summer): 311-326. 
137. Vaught, Carl G. 1985. Metaphor, Analogy, and System: A Reply to Burbidge. Man and World: An International Philosophical Review 18: 55-63.

138. Verburgge, Robert R., Nancy S. McCarrell. 1977. Metaphoric Comprehension: Studies in Reminding and Resembling. Cognitive Psychology 9, no. 4: 494-533.

139. Viana, Amadeu. 2001-2002. Fisuras Retóricas: Ironía, Analogí y Conocimiento Lingüístico. Cuadernos Sobre Vico 13-14: 233251.

140. Walczak, Steven. 2002. A Context-Based Computational Model of Language Acquisition by Infants and Children. Foundations of Science 7, no. 4 (December): 393-411.

141. Waltz, David L., Jordan B. Pollack. 1985. Massively Parallel Processing: A Strongly Interactive Model of Natural Language Interpretation. Cognitive Science 9, no. 1: 51-74.

142. Way, Eileen C. 1992. The dynamic type hierarchy theory of metaphor. In Conceptual structures: Current research and practice. Edited by T. E. Nagle, J. A. Nagle, L. L. Gerholz and P. W. Eklund. Upper Saddle River, NJ: Horwood.

143. Way, Eileen C. 1991. Knowledge representation and metaphor. Dordrecht: Kluwer Academic Publishers.

144. Wittgenstein, Ludwig. 2003. Philosophical investigations: The german text, with a revised english translation. Malden, MA: Blackwell Pub.

145. Wolff, Phillip, Dedre Gentner. 2000. Evidence for Role-Neutral Initial Processing of Metaphors. Journal of Experimental Psychology: Learning, Memory, and Cognition 26, no. 2: 529541.

146. Woods, John, Brent Hudak. 1992. Verdi is the Puccini of Music. Synthese 92, no. 2: 189-220.

147. Yablo, Stephen. 2002. De Facto Dependence. Journal of Philosophy 9, pt. 9, no. 3 (March): 130-148.

148. Zagal, Héctor. 2002. Substancia, Finalidad e Interpretación: La Actualidad de Metafísica IV. Suplementos de Contrastes: Revista Internacional de Filosofia 7: 175-192.

\subsection{Visual AnALOGY}

1. Anderson, Michael, Bernd Meyer, and Patrick Olivier ed. 2002. Diagrammatic representation and reasoning. Great Britain: Springer-Verlag London Limited.

2. Beveridge, M., E. Parkins. 1987. Visual Representation in Analogical Problem Solving. Memory \& Cognition 15, no. 3: 230-237.

3. Buchanan, Lori, Steve Joordens, Roy Fleck, and Paul Thagard. 1993. Orientation and Complexity Effects: Implications for Computational Models of Visual Analogical Reasoning. 
Proceedings of the Fifteenth Anual Conference of the Cognitive Science Society : 272-276.

4. Catrambone, Richard, David L. Craig, and Nancy J. Nersessian. 2006. The Role of Perceptually Represented Structure in Analogical Problem Solving. Memory and Cognition 34, no. Number 5 (July 2006): 1126-1132.

5. Clement, John. 2004. Imagistic processes in analogical reasoning: Conserving transformations and dual simulations. In Proceeding of the twenty-sixth annual conference of the cognitive science society. Mahwah, NJ: Erlbaum.

6. Craig, David L., Nancy J. Nersessian, and Richard Catrambone. 2002. Perceptual simulation in analogical problem solving. In Model-based reasoning: Science, technology, values. Edited by L. Magnani. Dordrecht: Kluwer Academic Pub.

7. Croft, David, Paul Thagard. 2002. Dynamic imagery: A computational model of motion and visual analogy. In Modelbased reasoning: Science, technology, values. Edited by Lorenzo Magnani. Dordrecht: Kluwer Academic Pub.

8. Davies, Jim, Ashok K. Goel, and Nancy J. Nersessian. 2005. A cognitive model of visual analogical problem-solving transfer. In Proceedings of the nineteenth annual international joint conference on artificial intelligence.

9. Feldman, Jerome A. 1981. A connectionist model of visual memory. In Parallel models of associative memory. Edited by G. E. Hinton and J. A. Anderson. Hillsdale, N.J.: Erlbaum.

10. Glasgow, Janice, Dimitri Papadias. 1992. Computational Imagery. Cognitive Science 16, no. 3: 355-394.

11. Goldstone, Robert L. 1994. Influences of Categorization on Perceptual Discrimination. Journal of Experimental Psychology: General 123, no. 2: 178-200.

12. Goldstone, Robert L., Lawrence W. Barsalou. 1998. Reuniting perception and conception. In Similarity and symbols in human thinking. Edited by S. A. Sloman and L. J. Rips. Amsterdam, the Netherlands: Elsevier Science Publishers, B.V.

13. Goldstone, Robert L., Douglas L. Medin. 1994. Time Course of Comparison. Journal of Experimental Psychology: Learning, Memory, and Cognition 20, no. 1:29-50.

14. Goldstone, Robert L., Douglas L. Medin. 1993. Similarity, interactive activation, and mapping. In Analogical connections (advances in connectionist and neural computation theory). Edited by K. J. Holyoak and J. A. Barnden. Norwood, N.J.: Ablex.

15. Goldstone, Robert L., Douglas L. Medin, and Dedre Gentner. 1991. Relational Similarity and the Non-Independence of Features in Similarity Judgments. Cognitive Psychology 23, no. 2: 222-262. 
16. Hristova, P., Boicho N. Kokinov. 2007. Perceptual learning vs. context-sensitive retrieval: Why do people judge green lines to be Shorter/Longer than red lines of the same length? do they perceive them differently or do they retrieve a biased set of alternatives in their comparison set? In Proceedings of the European conference on cognitive science377-382. Hillsdale, NJ: Erlbaum.

17. Kiryazov, K., G. Petkov, M. Grinberg, Boicho N. Kokinov, and C. Balkenius. 2007. The interplay of analogy-making with active vision and motor control in anticipatory robots. In ABiALS 2006, LNAI, vol. 4520. Edited by M. e. a. Butz. Berlin: Springer Verlag.

18. Kokinov, Boicho N., S. Bliznashki, S. Kosev, and P. Hristova. 2007. Analogical mapping and perception: Can mapping cause a re-representation of the target stimulus? In Proceedings of the 29th annual conference of the cognitive science society. Hillsdale, NJ: Erlbaum.

19. Leslie, Alan M. 1988. The necessity of illusion: Perception and thought in infancy. In Thought without language. Edited by L. Weiskrantz. Oxford: Oxford University Press.

20. Liebman, Henry. 1996. Intelligent Graphics. Comm. A.C.M. 39, no. 8: 38-48.

21. Nestor, A., Boicho N. Kokinov. 2004. Towards Active Vision in the DUAL Cognitive Architecture. International Journal on Information Theories \& Applications 11, no. 1: 9-15.

22. Petkov, G., K. Kiryazov, M. Grinberg, and Boicho N. Kokinov. 2007. Modeling top-down perception and analogical transfer with single anticipatory mechanism. In Proceedings of the European conference on cognitive science395-400. Hillsdale, NJ: Erlbaum.

23. Richland, Lindsey E., Robert G. Morrison, and Keith J. Holyoak. 2006. Children's Development of Analogical Reasoning: Insights from Scene Analogy Problems. Journal of Experimental Child Psychology 94, no. 3: 249-273.

24. Slade, Christina. 2003. Seeing Reasons: Visual Argumentation in Advertisements. Argumentation: An International Journal on Reasoning 17, no. 2: 145-160.

25. Stafford, Barbara M. 1999. Visual analogy: Consciousness as the art of connecting. Cambridge, MA: MIT Press.

26. Thagard, Paul, David Gochfeld, and Susan Hardy. 1992. Visual Analogical Mapping. Proceedings of the Fourteenth Annual Conference of the Cognitive Science Society : 522-527.

27. Townsend, Dabney. 2002. Book Review: Visual Analogy: Consciousness as the Art of Connecting. Philosophical Psychology 15, no. 1 (March): 97-100.

28. Zareva-Toncheva, Neda, Boicho N. Kokinov. 2003. Blending of spatial configurations--A result of co-activation or analogical mapping? In Constructive memory. Edited by B. N. Kokinov and W. Hirst. Sofia: NBU Press. 
176 Marcello Guarini et al.

\subsection{ANIMAL}

1. Gillian, Douglas J., David Premack, and Guy Woodruff. 1981. Reasoning in the Chimpanzee: I. Analogical Reasoning. Journal of Experimental Psychology: Animal Behavior Processes 7, no. 1: 1-17.

2. Kohler, Wolfgang. 1925. The mentality of apes. New York: Harcourt.

3. Lawrence, Douglas H., Joseph DeRivera. 1954. Evidence for Relational Transposition. Journal of Comparative and Physiological Psychology 47: 465-471.

4. Oden, David L., Thompson, Roger K. R., and David Premack. 2001. Can an ape reason analogically? comprehension and production of analogical problems by sarah, a chimpanzee (pan troglodytes) . In The analogical mind. Edited by D. Gentner, K. J. Holyoak and B. N. Kokinov. Cambridge, Mass.; London, England: MIT Press/ A Bradford Book.

5. Oden, David L., Thompson, Roger K. R., and David Premack. 1990. Infant Chimpanzees Spontaneously Perceive Both Concrete and Abstract Same/Different Relations. Child Development 61: 621-631.

6. Premack, David. 1988. Minds with and without language. In Thought without language. Edited by L. Weiskrantz. Oxford: Oxford University Press.

7. Premack, David. 1983. The Codes of Man and Beasts. Behavioral and Brain Sciences 6: 125-167.

8. Premack, David. 1976. Intelligence in ape and man. Hillsdale, N.J.: Erlbaum.

9. Premack, David, Guy Woodruff. 1978. Does the Chimpanzee Have a Theory of Mind? Behavioral and Brain Sciences 4: 515526.

10. Thompson, Roger K. R., D. L. Oden. 1993. "Language training" and its role in the expression of tacit propositional knowledge by chimpanzees (pan troglodytes). In Advances in the study of animal language. Edited by H. S. Roitblat, L. M. Herman and P. Nachtigall. Hillsdale, N.J.: Erlbaum.

\subsection{MEMORY OR RETRIEVAL}


1. Aristotle. 1984. On memory. In The complete works of Aristotle. Edited by J. Barnes. Princeton, NJ: Princeton University Press.

2. Barnden, John A. 1994. On the connectionist implementation of analogy and working memory matching. In Analogy, metaphor, and reminding (advances in connectionist and neural computation theory, vol. III). Edited by J. A. Barnden and K. J. Holyoak. Norwood, NJ: Ablex.

3. Day, Samuel B., Dedre Gentner. 2007. Nonintentional Analogical Inference in Text Comprehension. Memory and Cognition 35, no. 1: 39-49.

4. Forbus, Kenneth D., Dedre Gentner, and Keith Law. 1995. MAC/FAC: A Model of Similarity-Based Retrieval. Cognitive Science 19: 141-205.

5. Gentner, Dedre. 1988. Analogical inference and analogical access. In Analogica. Edited by A. Prieditis. Los Altos, CA: Kaufmann.

6. Gentner, Dedre. 1987. Analogical inference and analogical access. Urbana, Ill.: Dept. of Computer Science, University of Illinois at Urbana-Champaign.

7. Gentner, Dedre, Jeffrey Loewenstein, and Leigh Thompson. 2004. Analogical Encoding: Facilitating Knowledge Transfer and Integration. Proceedings of the Twenty-Sixth Annual Meeting of the Cognitive Science Society .

8. Gentner, Dedre, Mary J. Rattermann, and Kenneth D. Forbus. 1993. The Roles of Similarity in the Development of Analogy: Separating Retrieval from Inferential Soundness. Cognitive Psychology 25, no. 4: 524-575.

9. Grinberg, M., Boicho N. Kokinov. 2003. Analogy-based episode blending in AMBR. In Constructive memory. Edited by $\mathrm{B} . \mathrm{N}$. Kokinov and W. Hirst. Sofia: NBU Press.

10. Kokinov, Boicho N. 2006. Analogy and constructive memory. In Proceedings of the international conference on cognitive modelling (ICCM-06).

11. Kokinov, Boicho N. 2003. The mechanisms of episode construction and blending in DUAL and AMBR: Interaction between memory and analogy. In Constructive memory. Edited by B. N. Kokinov and W. Hirst. Sofia: NBU Press.

12. Kokinov, Boicho N. 1989. About modeling some aspects of human memory. In Man-computer interaction research MACINTER-II. Edited by F. Klix, Y. Waern and H. Wandke. Amsterdam, the Netherlands: Elsevier Science Publishers.

13. Kokinov, Boicho N. 1988. Associative memory-based reasoning: How to represent and retrieve cases. In Artificial intelligence III: Methodology, systems, applications. Edited by T. O'Shea and V. Sgurev. Amsterdam, the Netherlands: Elsevier Science Publishers. 
14. Kokinov, Boicho N., and W. Hirst ed. 2003. Constructive memory. Sofia: NBU Press.

15. Kokinov, Boicho N., V. Nikolov. 1989. Associative memorybased reasoning: A computer simulation. In Artificial intelligence and information-control systems of robots. Edited by I. Plander and J. Miklosko. Amsterdam, the Netherlands: Elsevier Science Publishers.

16. Kokinov, Boicho N., Neda Zareva-Toncheva. 2001. Episode blending as a result of analogical problem solving. In Proceedings of the 23rd annual conference of the cognitive science society. Hillsdale, NJ: Erlbaum.

17. Logie, Robert H., and Kenneth J. Gilhooly ed. 1998. Working memory and thinking: Current issues in thinking and reasoning. Hove: The Psychology Press.

18. Markman, Arthur B., Dedre Gentner. 2005. Nonintentional similarity processing. In The new unconscious. Edited by R. R. Hassin, J. A. Bargh and J. S. Uleman. New York: Oxford University Press.

19. Markman, Arthur B., Dedre Gentner. 1997. The Effects of Alignability on Memory Storage. Psychological Science 8, no. 5: 363-367.

20. Markman, Arthur B., Eric Taylor, and Dedre Gentner. 2007. Auditory Presentation Leads to Better Analogical Retrieval than Written Presentation. Psychonomic Bulletin \& Review 14: 11011106.

21. Perrott, David A., Dedre Gentner, and Galen V. Bodenhausen. 2005. Resistance is Futile: The Unwitting Insertion of Analogical Inferences in Memory. Psychonomic Bulletin \& Review 12, no. 4: 696-702.

22. Petrov, Alexander A., Boicho N. Kokinov. 1998. Mapping and access in analogy-making: Independent or interactive? A simulation experiment with AMBR. In Advances in analogy research: Integration of theory and data from the cognitive, computational, and neural sciences. Edited by K. J. Holyoak, D. Gentner and B. N. Kokinov. Sofia: NBU Press.

23. Roverso, Davide. 1996. Analogy Access by Mapping Spreading and Abstraction in Large, Multifunctional Knowledge Bases. IMCL : 418-426.

24. Thagard, Paul, Keith J. Holyoak, Greg Nelson, and David Gochfeld. 1990. Analog Retrieval by Constraint Satisfaction. Artificial Intelligence 46: 259-310.

25. Wharton, C. M., Keith J. Holyoak, P. E. Downing, T. E. Lange, T. D. Wickens, and Eric R. Melz. 1994. Below the Surface: Analogical Similarity and Retrieval Competition in Reminding. Cognitive Psychology 26, no. 2: 64-101.

26. Zareva-Toncheva, Neda, Boicho N. Kokinov. 2003. Blending of non-similar episodes as a result of analogical mapping with a 
third one. In Proceedings of the 25th annual conference of the cognitive science society. Hillsdale, NJ: Erlbaum.

\subsection{LoGIC}

1. Boole, George. 1951. An investigation of the laws of thought. New York: Dover.

2. Copi, Irving. 1979. Symbolic logic. New York: Macmillan.

3. Copi, Irving, and Keith Burgess-Jackson. 1996. Informal logic. Upper Saddle River, NJ: Prentice Hall.

4. Copi, Irving, and Carl Cohen. 2005. Introduction to logic. Upper Saddle River, N.J.: Pearson/Prentice Hall.

5. Finocchiaro, Maurice. 2007. Arguments, Meta-Arguments, and Metadialogues: A Reconstruction of Krabbe, Govier, and Woods. Argumentation: An International Journal on Reasoning 21, no. 3: 253-268.

6. Govier, Trudy. 1985. Logical Analogies. Informal Logic 7, no. 1: 27-33.

7. Oliver, James W. 1967. Formal Fallacies and Other Invalid Arguments. Mind 76: 463-478.

8. Sacksteder, William. 1979. Analogy: Justification for Logic. Philosophy and Rhetoric 12 (Winter): 21-40.

9. Sacksteder, William. 1974. The Logic of Analogy. Philosophy and Rhetoric 7 (Fall): 234-252.

10. van Evra, James. 1994. Logic and mathematics in Charles Sanders Peirce's description of a notation for the logic of relatives. In Studies in the logic of Charles Sanders Peirce. Edited by N. Houser, D. Roberts and J. van Evra. Indianapolis: Indiana University Press.

\subsection{VARIOUS}

1. Adler, Jonathan E. 2007. Asymmetical Analogical Arguments. Argumentation: An International Journal on Reasoning 21, no. 1: 83-92.

2. Agassi, Joseph. 1988. Analogies hard and soft. In Analogical reasoning: Perspectives of artificial intelligence, cognitive science, and philosophy. Edited by Anonymous Dordrecht: Kluwer Academic Publishing.

3. Arikawa, Setsuo, and Klaus P. Jantke. 1994. Algorithmic learning theory : 4th international workshop on analogical and inductive inference, AII '94, 5th international workshop on algorithmic learning theory, ALT '94, Reinhardsbrunn castle, Germany, october 10-15, 1994 : Proceedings. Berlin ; New York: SpringerVerlag. 
4. Arima, Jun. 1997. Preduction: A Common Form of Induction and Analogy. Proceedings of the Fifteenth International Joint Conference on Artificial Intelligence 1: 210-215.

5. Arima, Jun. 1992. Logical Structure of Analogy: Preliminary Report. Proceedings of the International Conference on Fifth Generation Computer Systems : 505-513.

6. Aristotle. 1984. Posterior analytics. In The complete works of Aristotle. Edited by J. Barnes. Princeton, NJ: Princeton University Press.

7. Aristotle. 1984. Prior analytics. In The complete works of Aristotle. Edited by J. Barnes. Princeton, NJ: Princeton University Press.

8. Aristotle. 1984. Topics. In The complete works of Aristotle. Edited by J. Barnes. Princeton, NJ: Princeton University Press.

9. Bachmann, Thomas. 1997. Creating analogies: On aspects of the mapping process between knowledge domains. Amsterdam: Rodopi.

10. Barker, Evelyn M. 1989. Beardsley's Theory of Analogy. Informal Logic 11, no. 3 (Fall): 185-194.

11. Barker, Stephen F. 2003. The elements of logic. Boston: McGrawHill.

12. Barker, Stephen F. 1989. Analogy in Hume's Dialogues. Informal Logic 11, no. 3: 173-184.

13. Barkowsky, Thomas, Markus Knauff, Gérard Ligozat, and Daniel R. Montello ed. 2007. Spatial cognition V: Reasoning, action, interaction. Berlin: Springer-Verlag.

14. Beardsley, Monroe C. 1975. Thinking straight. Englewood: Prentice Hall.

15. Berg, Jan. 1987. Bolzano on Induction. Philosophia Naturalis 24: 442-446.

16. Bezdek, James C., Didier Dubois, and Henri Prade ed. 1999. Fuzzy sets in approximate reasoning and information systems. Dordrecht: Kluwer Academic Publishers.

17. Bhansali, Sanjay. 1991. Domain-Based Program Synthesis Using Planning and Derivational Analogy. AI Magazine 12, no. 3: 3133.

18. Boden, Margaret A. 1990. The creative mind: Myths and mechanisms. New York: Basic Books.

19. Boden, Margaret A. 1988. Computer models of mind. Cambridge: Cambridge University Press.

20. Bowdle, Brian F., Dedre Gentner. 1997. Informativity and Asymmetry in Comparisons. Cognitive Psychology 34, no. 3: 244-286.

21. Braet, Antoine C. 2004. The Oldest Typology of Argumentation Schemes. Argumentation: An International Journal on Reasoning 18, no. 1: 127-148. 
22. Brown, William R. 1995. The Domain Constraint on Analogy and Analogical Argument. Informal Logic 17, no. 1 (Winter): 89-100.

23. Brown, William R. 1989. Two Traditions of Analogy. Informal Logic 11, no. 3 (Fall): 161-172.

24. Burns, Bruce D., Keith J. Holyoak. 1994. Competing models of analogy: ACME versus copycat. In Proceedings of the sixteenth annual conference of the cognitive science society. Hillsdale, N.J.: Erlbaum.

25. Burns, Bruce D., Maureen E. Schreiner. 1992. Analogy and Representation: Support for the Copycat Model. Proceedings of the Fourteenth Annual Conference of the Cognitive Science Society: 737-742.

26. Burstein, Mark H. 1988. Combining analogies in mental models. In Analogical reasoning: Perspectives of artificial intelligence, cognitive science, and philosophy. Edited by D. H. Helman. Dordecht: Kluwer Academic Publishers.

27. Camacho, Luis A. 1988. Hacia Una Logica De La Argumentacion Por Analogia. Revista Latinoamericana de Filosofia 14 (March): 79-87.

28. Chalmers, David J., Robert M. French, and Douglas R. Hofstadter. 1991. High-Level Perception, Representation, and Analogy: A Critique of Artificial Intelligence Methodology. Indiana University: Center for Research in Concepts and Cognition.

29. Chouraqui, Eugène. 1982. Construction of a Model for Reasoning by Analogy. Proceedings of the 5th European Conference on Artificial Intelligence : 48-53.

30. Cikoski, John S. 1975. On Standards of Analogic Reasoning in the Late Chou. Journal of Chinese Philosophy 2 (June): 325-357.

31. Clark, Andy, Jesus Ezquerro, and Jesus M. Larrazabal ed. 1996. Philosophy and cognitive science: Categories, consciousness, and reasoning. Dordrecht: Kluwer Academic Publishers.

32. Clement, Catherine A., Dedre Gentner. 1991. Systematicity as Selections Constraint in Analogical Mapping. Cognitive Science 15: 89-132.

33. Cohen, Laurence J. 1989. An introduction to the philosophy of induction and probability. Oxford; New York: Clarendon Press; Oxford University Press.

34. Collins, Allan, Dedre Gentner. 1987. How people construct mental models. In Cultural models of language and thought. Edited by D. Holland and N. Quinn. England: Cambridge University Press.

35. Davies, Todd R. 1988. Determination, uniformity, and relevance: Normative criteria for generalization and reasoning by analogy. In Analogical reasoning: Perspectives of artificial intelligence, cognitive science, and philosophy. Edited by D. H. Helman. Dordrecht: Kluwer Academic Pub. 
36. Davies, Todd R., Stuart Russell. 1987. A Logical Approach to Reasoning by Analogy. Proceedings of the 10th International Joint Conference on Artificial Intelligence : 264-270.

37. De Sousa, Ronald. 1987. The rationality of emotion. Cambridge, Mass.: MIT Press.

38. Défourneaux, Gilles, Nicolas Peltier. 1997. Analogy and Abduction in Automated Deduction. IJCAI-97 1, no. 216: 225.

39. Dingyi, Lin. 1985. Analogy and Association. Chinese Studies in Philosophy 16 (Summer): 92-107.

40. Eliasmith, Chris, Paul Thagard. 2001. Integrating Structure and Meaning: A Distributed Model of Analogical Mapping. Cognitive Science 25: 245-286.

41. Facione, Peter A., and Noreen C. Facione. 2007. Thinking and reasoning in human decision making: The method of argument and heuristic analysis. Millbrae, CA: The California Academic Press.

42. Falkenhainer, Brian, Kenneth D. Forbus, and Dedre Gentner. 1989. The Structure-Mapping Engine: Algorithms and Examples. Artificial Intelligence 41, no. 1: 1-63.

43. Fauconnier, Gilles. 2001. Conceptual blending and analogy. In The analogical mind. Edited by D. Gentner, K. J. Holyoak and B. N. Kokinov. Cambridge, Mass.; London, England: MIT Press/ A Bradford Book.

44. Fauconnier, Gilles, and Mark Turner. 2002. The way we think, conceptual blending and the mind's hidden complexities. New York, NY: Basic Books.

45. Fauconnier, Gilles, Mark Turner. 1998. Conceptual Integration Networks. Cognitive Science 22, no. 2: 133-187.

46. Feldman, Jerome A., Dana H. Ballard. 1982. Connectionist Models and their Properties. Cognitive Science 6: 205-254.

47. Forbus, Kenneth D. 2001. Exploring analogy in the large. In The analogical mind. Edited by D. Gentner, K. J. Holyoak and B. N. Kokinov. Cambridge, Mass.; London, England: MIT Press/ A Bradford Book.

48. Forbus, Kenneth D., Ronald W. Ferguson, and Dedre Gentner. 1994. Incremental structure-mapping. In 313-318.

49. Forbus, Kenneth D., Dedre Gentner, Arthur B. Markman, and Ronald W. Ferguson. 1998. Analogy Just Looks Like High-Level Perception: Why a Domain-General Approach to Analogical Mapping is Right. Journal of Experimental and Theoretical Artificial Intelligence 10, no. 2: 231-257.

50. Forbus, Kenneth D., Dan Oblinger. 1990. Making SME greedy and pragmatic. In 61-68. Hillsdale, N.J.: Erlbaum.

51. Frazer, Catherine F. 1970. Hume's Criticism and Defense of Analogical Argument. Journal of the History of Philosophy 8 (April): 173-179. 
52. Freeney, Aidan, and Evan Heit ed. 2007. Inductive reasoning: Experimental, developmental and computational approaches. Cambridge: Cambridge University Press.

53. French, Robert M. 1995. The subtlety of similarity: A theory and computer model of analogy-making. Cambridge, M.A.: MIT Press.

54. Frogel, Shai. 2004. Philosophical Argumentation: Logic and Rhetoric. Argumentation: An International Journal on Reasoning 18, no. 2: 171-188.

55. Furtado, Antonio L. 1992. Analogy by Generalization--And the Quest of The Grail. SIGPLAN Notices 27, no. 1: 105-113.

56. Ganeri, Jonardon. June 2003. Ancient Indian Logic As a Theory of Case-Based Reasoning. Journal of Indian Philosophy 31, no. 1-3: 33-45.

57. Garnham, Alan, and Jane Oakhill. 1994. Thinking and reasoning. Oxford: Blackwell.

58. Gattis, Merideth. 2004. Mapping Relational Structure in Spatial Reasoning. Cognitive Science 28, no. 4: 589-610.

59. Gebhardt, Friedrich, Angi Voß, Wolfgang Gräther, and Barbara Schmidt-Belz. 1997. Reasoning with complex cases. Norwell, Massachusetts: Kluwer Academic Publishers.

60. Gentner, Dedre. 2002. Analogical reasoning, psychology of. In Encyclopedia of cognitive science. Edited by L. Nadel. London: Nature Publishing Group.

61. Gentner, Dedre. 2002. Mental models, psychology of. In International encyclopedia of social and behavioral sciences. Edited by N. J. Smelser and P. B. Baltes. Amsterdam: Elsevier Science.

62. Gentner, Dedre. 2001. Analogy. In The MIT encyclopedia of the cognitive sciences. Edited by R. A. Wilson and F. C. Keil. Cambridge, MA: MIT Press.

63. Gentner, Dedre. 1998. Analogy. In A companion to cognitive science. Edited by W. Bechtel and G. Graham. Oxford: Blackwell.

64. Gentner, Dedre. 1990. Analogies. In Dictionary of cognitive psychology. Edited by M. W. Eysenck. Oxford: Blackwell.

65. Gentner, Dedre. 1983. Structure Mapping: A Theoretical Framework for Analogy. Cognitive Science 7: 155-170.

66. Gentner, Dedre, Keith J. Holyoak, and Boicho N. Kokinov ed. 2001. The analogical mind: Perspectives from cognitive science. Cambridge, MA: MIT Press.

67. Gentner, Dedre, Kenneth Kurtz. 2006. Relations, Objects, and the Composition of Analogies. Cognitive Science 30: 609-642.

68. Gentner, Dedre, Arthur B. Markman. 2006. Defining Structural Similarity. Journal of Cognitive Science 6: 1-20.

69. Gentner, Dedre, Arthur B. Markman. 1997. Structure Mapping in Analogy and Similarity. American Psychologist 52, no. 1: 45-56. 
70. Gentner, Dedre, Arthur B. Markman. 1996. Review of the book: Mental Leaps: Analogy in Creative Thought. Pragmatics \& Cognition 4, no. 2: 407-409.

71. Gentner, Dedre, Arthur B. Markman. 1995. Analogy-based reasoning in connectionism. In The handbook of brain theory and neural networks. Edited by M. A. Arbib. Cambridge, MA: MIT Press.

72. Gentner, Dedre, Arthur B. Markman. 1994. Structural Alignment in Comparison: No Difference without Similarity. Psychological Science 5, no. 3: 152-158.

73. Gentner, Dedre, Arthur B. Markman. 1993. Analogy--watershed or waterloo? structural alignment and the development of connectionist models of cognition. In Advances in neural information processing systems. Edited by D. Cowan and C. L. Giles. San Mateo, CA: Kaufmann.

74. Gentner, Dedre, Eyal Sagi. 2006. Does "different" imply a difference? A comparison of two tasks. In Proceedings of the twenty-eighth annual meeting of the cognitive science society, edited by R. Sun, N. Miyake, 261-266.

75. Gentner, Dedre, and Albert L. Stevens ed. 1983. Mental models. Hillsdale, N.J.: Lawrence Erlbaum Associates.

76. Goebel, Randy. 1989. A Sketch of Analogy as Reasoning with Equality Hypotheses. Analogical and Inductive Inference: Proceedings of the International Workshop in Artificial Intelligence 397: 243-253.

77. Govier, Trudy. 2005. A practical study of argument. Australia ; Belmont, CA: Thomson/Wadsworth.

78. Govier, Trudy. 2002. Should a priori Analogies be Regarded as Deductive Arguments? Informal Logic 22, no. 2: 155-157.

79. Govier, Trudy. The Philosophy of Argument. Newport News (Newport) . 1999.

80. Govier, Trudy. 1989. Analogies and Missing Premises. Informal Logic 11, no. 3: 141-152.

81. Govier, Trudy. 1987. Problems in argument analysis and evaluation. Dordrecht: Foris Publishers.

82. Greeno, James G., William J. Clancey, Clayton Lewis, Mark Seidenberg, Sharon Derry, Morton A. Gernsbacher, Patrick Langley, Michael Shafto, Dedre Gentner, Alan Lesgold, and Colleen M. Seifert. 1998. Efforts to Encourage Multidisciplinarity in the Cognitive Science Society. Cognitive Science 22, no. 1: 131-132.

83. Haase, Kenneth B. 1995. Analogy in the Large. Proceedings of the Fourteenth International Joint Confernce on Artificial Intelligence : 1375-1381.

84. Hahn, Ulrike, Nick Chater. 1998. Similarity and rules: Distinct? exhaustive? empirically distinguishable? In Similarity and symbols in human thinking. Edited by S. A. Sloman and L. J. 
Rips. Amsterdam, the Netherlands: Elsevier Science Publishers, B.V.

85. Halford, Graeme S., William H. Wilson, Jian Guo, Ross W. Gayler, Janet Wiles, and J. E. M. Stewart. 1994. Connectionist implications for processing capacity limitations in analogies. In Analogical connections, vol. 2, advances in connectionist and neural computation theory. Edited by K. J. Holyoak and J. A. Barnden. Norwood, N.J.: Ablex.

86. Hall, Rogers P. 1989. Computational Approaches to Analogical Reasoning: A Comparative Analysis. Artificial Intelligence 39, no. 1: 39-120.

87. Harman, Gilbert. 1986. Change in view: Principles of reasoning. Cambridge, Mass.: MIT Press/ Bradford Books.

88. Helman, David H. ed. 1988. Analogical reasoning : Perspectives of artificial intelligence, cognitive science, and philosophy. Dordrecht ; Boston: Kluwer Academic Publishers.

89. Hesse, Mary. 1965. Aristotle's Logic of Analogy. Philosophical Quarterly 15 (October): 328-340.

90. Hesse, Mary. 1960. On Defining Analogy. Proceedings of the Aristotelian Society 60: 79-100.

91. Hitchcock, David. 1992. Reasoning by analogy. In In the generalizability of critical thinking: Multiple perspectives on an educational ideal. Edited by S. P. Norris. New York; London: Teacher's College Press.

92. Hoaglund, John. 1999. Critical thinking. Newport: Vale Press.

93. Hoffman, Robert R. 1998. AI Models of Verbal/ Conceptual Analogy. Journal of Experimental \& Theoretical Artificial Intelligence 10, no. 2: 259-286.

94. Hofstadter, Douglas R. 1995. A Review of Mental Leaps: Analogy in Creative Thought. AI Magazine 16, no. 3: 75-80.

95. Hofstadter, Douglas R. 1984. The copycat project: An experiment in nondeterminism and creative analogies. AI Memo 755 .

96. Hofstadter, Douglas R., and Fluid Analogies Research Group. 1995. Fluid concepts \& creative analogies: Computer models of the fundamental mechanisms of thought. New York: Basic Books.

97. Hofstadter, Douglas R., Melanie Mitchell. 1994. The CopyCat project: A model of mental fluidity and analogy-making. In Analogical connections (advances in connectionist and neural computation theory, vol. II). Edited by K. J. Holyoak and J. A. Barnden. Norwood, NJ: Ablex.

98. Hofstadter, Douglas R., Melanie Mitchell. 1988. Conceptual Slippage and Mapping: A Report of the Copycat Project. Proceedings fo the Tenth Annual Conference of the Cognitive Science Society : 601-607.

99. Holland, John H. 1975. Adaptation in natural and artificial systems. Ann Arbor: University of Michigan Press. 
100. Holland, John H., Keith J. Holyoak, Richard E. Nisbett, and Paul Thagard. 1986. Induction: Processes of inference, learning, and discovery. Cambridge, Mass.: MIT Press.

101. Holyoak, Keith J. 2005. Analogy. In The Cambridge handbook of thinking and reasoning. Edited by K. J. Holyoak and R. G. Morrison. New York: Cambridge University Press.

102. Holyoak, Keith J. 1991. Symbolic connectionism: Toward thirdgeneration theories of expertise. In Toward a general theory of expertise: Prospects and limits. Edited by K. A. Ericsson and J. Smith. Cambridge: Cambridge University Press.

103. Holyoak, Keith J. 1987. A Connectionist View of Cognition. Review of Parallel Distributed Processing, by D. E. Rumelhart, J. L. McClelland, and the PDP Research Group. Science 236: 992-996.

104. Holyoak, Keith J. 1984. Analogical thinking and human intelligence. In Advances in the psychology of human intelligence. Edited by R. J. Sternberg. Hillsdale, N.J.: Erlbaum.

105. Holyoak, Keith J., and John A. Barnden ed. 1994. Analogical connections (advances in connectionist and neural computation theory, vol. II). Norwood, NJ: Ablex.

106. Holyoak, Keith J., Dedre Gentner, and Boicho N. Kokinov. 2001. Introduction: The place of analogy in cognition. In The analogical mind: Perspectives from cognitive science. Edited by D. Gentner, K. J. Holyoak and B. N. Kokinov. Cambridge, MA: MIT Press.

107. Holyoak, Keith J., Dedre Gentner, and Boicho N. Kokinov ed. 1998. Advances in analogy research: Integration of theory and data from the cognitive, computational, and neural sciences. Sofia: New Bulgarian University.

108. Holyoak, Keith J., John E. Hummel. 2001. Toward and understanding of analogy within a biological symbol system. In The analogical mind. Edited by D. Gentner, K. J. Holyoak and B. N. Kokinov. Cambridge, Mass: MIT Press, A Bradford Book.

109. Holyoak, Keith J., Kyunghee Koh. 1987. Surface and Structural Similarity in Analogical Transfer. Memory and Cognition 15, no. 4: 332-340.

110. Holyoak, Keith J., and Robert G. Morrison ed. 2005. The Cambridge handbook of thinking and reasoning. New York: Cambridge University Press.

111. Holyoak, Keith J., Laura R. Novick, and Eric R. Melz. 1994. Component processes in analogical transfer: Mapping, pattern completion, and adaptation. In Analogical connections (advances in connectionist and neural computation theory, vol.II). Edited by K. J. Holyoak and J. A. Barnden. Norwood, N.J.: Ablex.

112. Holyoak, Keith J., Barbara A. Spellman. 1993. Thinking. Annual Review of Psychology 44: 265-315. 
113. Holyoak, Keith J., Paul Thagard. 1997. The Analogical Mind. American Psychologist 52: 35-44.

114. Holyoak, Keith J., and Paul Thagard. 1995. Mental leaps: Analogy in creative thought. Cambridge, Mass.: MIT Press.

115. Holyoak, Keith J., Paul Thagard. 1989. Analogical Mapping by Constraint Satisfaction. Cognitive Science 13: 295-355.

116. Hospers, John. 1967. An introduction to philosophical analysis. London: Routledge \& K. Paul.

117. Hugon, Pascale. 2008. Arguments by Parallels in the Epistemological Works of Phya pa Chos kyi seng ge. Argumentation: An International Journal on Reasoning 22, no. 1: 93-114.

118. Hume, David. 1888. A treatise of human nature. Oxford: Clarendon Press.

119. Hummel, John E., Bruce D. Burns, and Keith J. Holyoak. 1994. Analogical mapping by dynamic binding: Preliminary investigations. In Advances in connectionist and neural computation theory: Analogical connections. Edited by Anonymous Norwood, NJ.: Ablex.

120. Hummel, John E., Keith J. Holyoak. 1997. Distributed Representations of Structure: A Theory of Analogical Access and Mapping. Psychological Review 104: 427-466.

121. Hummel, John E., Keith J. Holyoak. 1997. LISA: A Computational Model of Analogical Inference and Schema Induction. Psychological Review 104, no. 3: 427-466.

122. Hummel, John E., Keith J. Holyoak. 1992. Indirect Analogical Mapping. Proceedings of the Fourteenth Annual Conference fo the Cognitive Science Society : 516-521.

123. Hummel, John E., Eric R. Melz, Jeff Thompson, and Keith J. Holyoak. 1994. Mapping hierarchical structures with synchrony for binding: Preliminary investigations. In Proceedings of the sixteenth annual conference of the cognitive science society. Hilsdale, N.J.: Erlbaum.

124. Hunter, Lynette ed. 1991. Toward a definition of topos: Approaches to analogical reasoning. Palgrave Macmillan.

125. Jameson, Jason, Dedre Gentner. 2003. Mundane comparisons can facilitate relational understanding. In Proceedings of the twentyfifth annual meeting of the cognitive science society.

126. Jantke, Klaus P. 1992. Analogical and inductive inference: International workshop AII '92, dagstuhl castle, Germany, october 1992 : Proceedings. Berlin; New York: Springer-Verlag.

127. Jevons, Stanley W. 2005. The substitution of similars: The true principle of reasoning, derived from a modification of Aristotle's dictum. Adamant Media Corporation/ Elibron Clasics Series.

128. Johnson, Fred. 1989. Analogical Arguings and Explainings. Informal Logic 11, no. 3 (Fall): 153-160. 
129. Johnson, Mark. 1988. Some constraints on embodied analogical understanding. In Analogical reasoning: Perspectives of artificial intelligence, cognitive science, and philosophy. Edited by D. H. Helman. Dordrecht: Kluwer.

130. Johnson-Laird, Philip N. 1988. The computer and the mind. Cambridge, Mass.: Harvard University Press.

131. Johnson-Laird, Philip N. 1983. Mental models. Cambridge, Mass.: Harvard University Press.

132. Juthe, A. 2005. Argument by Analogy. Argumentation: An International Journal on Reasoning 19, no. 1: 1-27.

133. Keane, Mark T. 1990. Incremental analogising: Theory and model. In Lines of thinking: Reflections on the psychology of thought. Edited by K. J. Gilhooly, M. T. Keane, R. H. Logie and G. Erdos. Chichester, England: John Wiley \& Sons.

134. Keane, Mark T. 1990. What Makes Analogy Difficult? The Effects of Order and Causal Structure on Analogical Mapping. Journal of Expirimental Psychology 23, no. 4: 946-967.

135. Keane, Mark T. 1988. Where's the beef? the absence of pragmatic factors in pragmatic theories of analogy. In 8th European conference on artificial intelligence327-332.

136. Keane, Mark T., Fintan Costello. 2001. Setting limits on analogy: Why conceptual combination is not structural alignment. In The analogical mind. Edited by D. Gentner, K. J. Holyoak and B. N. Kokinov. Cambridge, Mass; London, England: MIT Press/ A Bradford Book.

137. Keane, Mark T., Tim Ledgeway, and Stuart Duff. 1994. Constraints on Analogical Mapping: A Comparison of Three Models. Cognitive Science 18: 387-438.

138. Kedar-Cabelli, Smadar. 1988. Analogy--from a unified perspective. In Analogical reasoning: Perspectives of artificial intelligence, cognitive science, and philosophy. Edited by D. H. Helman. Dordrecht: Kluwer Academic Publishers.

139. Kellert, Stephen H. 2001. Extrascientific Uses of Physics: The Case of Nonlinear Dynamics and Legal Theory. Philosophy of Science 68, pt. 3, no. suppl. (September): S455-S466.

140. Keynes, John M. 1979. A treatise on probability. New York: AMS Press.

141. King, Robert E. 1970. A Paradigm for Reasoning by Analogy. Artificial Intelligence 2, no. 2: 147-178.

142. Kodratoff, Yves. 1990. Combining similarity and causality in creative analogy. In 9th European conference on artificial intelligence398-403.

143. Koestler, Arthur. 1964. The act of creation. New York: Macmillan.

144. Kokinov, Boicho N. 1998. Analogy is like cognition: Dynamic, emergent, and context-sensitive. In Advances in analogy research: Integration of theory and data from the cognitive, 
computational, and neural sciences. Edited by K. J. Holyoak, D. Gentner and B. N. Kokinov. Sofia: NBU Press.

145. Kokinov, Boicho N. 1994. A hybrid model of reasoning by analogy. In Advances in connectionist and neural computation theory (analogical connections, vol. II). Edited by K. J. Holyoak and J. A. Barnden. Norwood, NJ: Ablex.

146. Kokinov, Boicho N. 1992. Inference evaluation in deductive, inductive and analogical reasoning. In Proceedings of the 14th annual conference of the cognitive science society903-908. Hillsdale, NJ: Erlbaum.

147. Kokinov, Boicho N. 1992. Similarity in analogical reasoning. In Artificial intelligence III: Methodology, systems, applications. Edited by V. Sgurev and B. du Boulay. Amsterdam, the Netherlands: Elsevier Science Publishers.

148. Kokinov, Boicho N., Robert M. French. 2003. Computational models of analogy-making. In Encyclopedia of cognitive science. Edited by L. Nadel. London: Nature Publishing Group.

149. Kokinov, Boicho N., Alexander A. Petrov. 2001. Integrating memory and reasoning in analogy-making: The AMBR model. In The analogical mind. Edited by D. Gentner, K. J. Holyoak and B. N. Kokinov. Cambridge, Mass.; London, England: MIT Press/ A Bradford Book.

150. Kolodner, Janet. 1993. Case-based reasoning. San Mateo, CA: Morgan Kaufmann.

151. Kolodner, Janet, Robert Simpson. 1989. The MEDIATOR: Analysis of an Early Case-based Problem Solver. Cognitive Science 13, no. 4: 507-549.

152. Kuipers, Theo A. F. 1988. Inductive analogy by similarity and proximity. In Analogical reasoning: Perspectives of artificial intelligence, cognitive science, and philosophy. Edited by D. H. Helman. Dordrecht: Kluwer Academic Pub.

153. Kurtz, Kenneth, Dedre Gentner, and Virginia Gunn. 1999. Reasoning. In Cognitive science: Handbook of perception and cognition. Edited by D. E. Rumelhart and B. M. Bly. San Diego: Academic Press.

154. Lakemeyer, Gerhard, and Bernhard Nebel ed. 1994. Foundations of knowledge representation and reasoning. Berlin: SpringerVerlag.

155. Leighton, Jacqueline, and Robert J. Sternberg ed. 2004. The nature of reasoning. Cambridge: Cambridge University Press.

156. Leishman, Debbie. 1989. Analogy as a Constrained Partial Correspondence Over Conceptual Graphs. Proceedings of the First International Conference on Principles of Knowledge Representation and Reasoning : 223-234.

157. Lloyd, Geoffrey E. R. 1966. Polarity and analogy: Two types of argumentation in early greek thought. Cambridge: Cambridge University Press. 
158. Lovett, Andrew, Dedre Gentner, and Kenneth D. Forbus. 2006. Simulating Time-Course Phenomena in Perceptual Similarity via Incremental Encoding. Proceedings of the Twenty-Eighth Annual Meeting of the Cognitive Science Society: 1723-1728.

159. Lumer, Christoph. 2000. Reductionism in Fallacy Theory. Argumentation: An International Journal on Reasoning 14, no. 4: 405-423.

160. Lycan, William E. 1988. Critical Study of James Ross, Portraying Analogy. Linguistics and Philosophy 11, no. 1: 107124.

161. MacCormac, Earl R. 1975. Scientific and Religious Metaphors. Religious Studies: An International Journal for the Philosophy of Religion 11 (December): 401-409.

162. Mackworth, Alan K. 1990. Constraint satisfaction. In Encyclopedia of artificial intelligence. Edited by S. C. Shapiro. New York: John Wiley.

163. MacLean, Allen, Victoria Bellotti, Richard Young, and Thomas P. Moran. 1991. Reaching Through Analogy: A Design Rationale Perspective on Roles of Analogy. Proceedings of ACM CHI'91 Conference on Human Factors in Computing Systems, Use of Familiar Things in the Design of Interfaces : 167-172.

164. Markman, Arthur B. 1997. Constraints on Analogical Inference. Cognitive Science 21, no. 4: 373-418.

165. Markman, Arthur B., Dedre Gentner. 2000. Structure-Mapping in the Comparison Process. American Journal of Psychology 113, no. 4: 501-538.

166. Markman, Arthur B., Dedre Gentner. 1996. Commonalities and Differences in Similarity Comparisons. Memory \& Cognition 24, no. $2: 235-249$.

167. Markman, Arthur B., Dedre Gentner. 1993. All differences are not created equal: A structural alignment view of similarity. In Proceedings of the fifteenth annual conference of the cognitive science society682-686. Hillsdale, N.J.: Erlbaum.

168. Markman, Arthur B., Dedre Gentner. 1993. Splitting the Differences: A Structural Alignment View of Similarity. Journal of Memory and Language 32, no. 4: 517-535.

169. Markman, Arthur B., Dedre Gentner. 1993. Structural Alignment During Similarity Comparisons. Cognitive Psychology 25: 431467.

170. Marx, Zvika, Ido Dagan, Joachim M. Buhmann, and Eli Shamir. 2002. Coupled Clustering: A Method for Detecting Structural Correspondence. Journal of Machine Learning Research 3: 747780 .

171. Mason, Zachary J. 2004. CorMet: A Computational, CorpusBased Conventional Metaphor Extraction System. Computational Linguistics 30, no. 1: 23-44. 
172. Maziarz, Edward A. 1975. Meta-Mathematics and MetaTheology: an Inquiry. Philosophia Mathematica 12 (Winter): 87123.

173. Medin, Douglas L. 1989. Concepts and Conceptual Structure. American Psychologist 44: 1469-1481.

174. Medin, Douglas L., Robert L. Goldstone, and Dedre Gentner. 1993. Respects for Similarity. Psychological Review 100, no. 2: 254-278.

175. Melis, Erica. 1995. A Model of Analogy-Driven Proof-Plan Construction. Proceedings of the 14th International Joint Conference on Artificial Intelligence : 182-189.

176. Mesarovic, Mihajlo D., Edward Henning. Analogy in the Creative Processes and the Objects of Creation in Art and Sciences. Dialectica: International Journal of Philosophy of Knowledge 17: 159-166.

177. Mill, John S. 1979. An examination of sir william hamilton's philosophy. Toronto: University of Toronto Press.

178. Mill, John S. 1970. A system of logic. London: Longman.

179. Mill, John S. 1963. Collected works. Toronto: University of Toronto Press.

180. Miller, George A. 1956. The Magical Number Seven, Plus or Minus Two: Some Limits on our Capacity for Processing Information. Psychological Review 63, no. 2: 81-97.

181. Miriyala, Kanth, Mehdi T. Harandi. 1991. The Role of Analogy in Specification Derivation. Proceedings of the 6th Annual Knowledge-Based Software Engineering Conference : 117-126.

182. Mitchell, Melanie. 1993. Analogy-making as perception. Cambridge, Mass.: MIT Press.

183. Moore, Brooke N., and Richard Parker. 1992. Critical thinking. Mountain View, CA.: Mayfield.

184. Morrison, Clayton T., Eric Dietrich. 1995. Structure-Mapping vs. High-Level Perception: The Mistaken Fight Over the Explanation of Analogy. Proceedings of the Nineteenth Annual Conference of the Cognitive Science Society: 678-682.

185. Mostow, Jack. 1990. Design by derivational analogy: Issues in the automated replay of design plans. In Machine learning: Paradigms and methods. Edited by J. G. Carbonell. Cambridge, Mass.: MIT Press.

186. Mueller, Erik T. 2006. Commonsense reasoning. San Francisco, CA: Morgan Kaufmann.

187. Nelson, Greg, Paul Thagard, and Susan Hardy. 1994. Integrating analogies with rules and explanations. In Analogical connections (advances in connectionist and neural computational theory, vol. II). Edited by J. A. Barnden and K. J. Holyoak. Norwood, N.J.: Ablex. 
188. Nisbett, Richard E., and Lee Ross. 1980. Human inference: Strategies and shortcomings of social judgement. Englewood Cliffs, N.J.: Prentice Hall.

189. O'donovan, Leo J. 1972. Methodology in some Recent Studies of Analogy. Philosophical Studies (Ireland) 16: 63-81.

190. Owen, Stephen. 1990. Analogy for automated reasoning. Orlando, FL: Academic Press.

191. Owen, Stephen. 1986. Heuristics for Analogy Matching. Seventh European Conference on Artificial Intelligence : 69-81.

192. Peirce, Charles S. 1934. Volume 5: Pragmatism and pragmaticism. In Collected papers, Charles Sanders Peirce. Edited by Anonymous Cambridge, Mass.: Belknap Press of Harvard University Press.

193. Peirce, Charles S. 1931. Volume 1: Principles of philosophy. In Collected papers, Charles Sanders Peirce. Edited by Anonymous Cambridge, Mass.: Belknap Press of Harvard University Press.

194. Peirce, Charles S. 1931. Volume 2: Elements of logic. In Collected papers, Charles Sanders Peirce. Edited by Anonymous Cambridge, Mass.: Belknap Press of Harvard University Press.

195. Perelman, Chaïm. 1969. Analogie et Metaphore en Science, Poesie et Philosophie. Revue Internationale de Philosophie 23: 315.

196. Perelman, Chaïm, and Lucie Olbrechts-Tyteca. 1969. The new rhetoric: A treatise on argumentation. Notre Dame, Ind.: University of Notre Dame Press.

197. Perner, Petra ed. 2008. Case-based reasoning on images and signals. Berlin: Springer-Verlag.

198. Petkov, G., Boicho N. Kokinov. 2006. JUDGEMAP - integration of analogy-making, judgment, and choice. In Proceedings of the 28 th annual conference of the cognitive science society. Hillsdale, NJ: Erlbaum.

199. Petkov, G., T. Naydenov, M. Grinberg, and Boicho N. Kokinov. 2007. Building robots with analogy-based anticipation. In $K I$ 2006, LNAI, vol. 4314. Edited by C. Freksa, M. Kohlhase and K. Schill. Berlin: Springer Verlag.

200. Pfütze, Hermann. 1996. Das formprinzip der kunst--zwischen natur und arbeit. In Ästhetik und naturerfahrung. Edited by J. Zimmerman. Stuttgart: Frommann-Holzboog.

201. Pickett, Marc. 2007. The Übercruncher: Concept Formation by Analogy Discovery. AAAI : 1941-1942.

202. Pisan, Yusuf. 2000. Extending Requirement Specifications Using Analogy. Proceedings of the 22nd International Conference on Software Engineering : 70-76.

203. Prieditis, Armand ed. 1988. Analogica (research notes in artificial intelligence). London: Pitman Publishing.

204. Putnam, Hilary. 1992. Renewing philosophy. Cambridge, Mass.: Harvard University Press. 
205. Quine, Willard V. O., and Joseph S. Ullian. 1978. The web of belief. New York: Random House.

206. Reed, Stephen K. 1987. A Structure-mapping Model for Word Problems. Journal of Experimental Psychology, Learning, Memory, and Cognition 13, no. 1: 124-139.

207. Reeves, Lauretta M., Robert W. Weisberg. 1994. The Role of Content and Abstract Information in Analogical Transfer. Psychological Bulletin 115, no. 3: 381-400.

208. Richards, I. A. 1936. The philosophy of rhetoric. London: Oxford University Press.

209. Richardson, Henry S. 1997. Practical reasoning about final ends. Cambridge: Cambridge University Press.

210. Riesbeck, Christopher K., and Roger C. Schank. 1989. Inside case-based reasoning. Hillsdale, N.J.: Erlbaum.

211. Rissland, Edwina L. 2006. AI and Similarity. IEEE Intelligent Systems 21, no. 3: 39-49.

212. Roberts, Maxwell J., and Elizabeth J. Newton ed. 2005. Methods of thought: Individual differences in reasoning strategies. East Sussex: Psychology Press.

213. Robin, Nina, Keith J. Holyoak. 1994. Relational complexity and the functions of prefrontal cortex. In The cognitive neurosciences. Edited by M. S. Gazzaniga. Cambridge, Mass.: MIT Press.

214. Ross, James F. 1981. Portraying analogy. Cambridge; New York: Cambridge University Press.

215. Rumelhart, David E., Paul Smolensky, Geoffrey Hinton, and James L. McClelland. 1986. Schemata and sequential thought processes in PDP models. In Parallel distributed processing: Explorations in the microstructure of cognition. Edited by J. L. McClelland and D. E. Rumelhart. Cambridge, Mass.: MIT Press.

216. Ross, James F. 1962. The Logic of Analogy, by Ralph McInerny. International Philosophical Quarterly 2 (December): 633-642.

217. Rumelhart, David E. 1980. Schemata: The building blocks of cognition. In Theoretical issues in reading comprehension. Edited by R. Spiro, B. Bruce and W. Brewer. Hillsdale, N.J.: Erlbaum.

218. Russell, Stuart. 1989. The use of knowledge in analogy and induction. London: Pitman.

219. Russell, Stuart. 1988. Analogy by similarity. In Analogical reasoning: Perspectives of artificial intelligence, cognitive science, and philosophy. Edited by D. H. Helman. Dordrecht: Kluwer Academic Pub.

220. Russell, Stuart. 1986. A Quantitative Analysis of Analogy by Similarity. Proceedings of the Fifth National Conference on Artificial Intelligence : 284-288.

221. Schank, Roger C., Alex Kass, and Christopher K. Riesbeck. 1994. Inside case-based explanation. Hillsdale, NJ: Erlbaum.

222. Schlimm, Dirk. 2006. Axiomatics and progress in the light of 20th century philosophy of science and mathematics. In 
Foundations of the formal sciences $I V$. Edited by B. Löwe, V. Peckhaus and T. Rasch. London: College Publications.

223. Scriven, Michael. 1976. Reasoning. New York: McGraw-Hill Book Company.

224. Shaw, Patrick. 1997. Logic and its limits. Oxford [England] ; New York: Oxford University Press.

225. Shaw, William H., Lawrence R. Ashley. 1983. Analogy and Inference. Dialogue: Canadian Philosophical Review 2, pt. 2 (September): 415-432.

226. Shepard, Roger N. 1975. Form, formation, and transformation of internal representations. In Information Processing and Cognition: The Loyola Symposium, edited by R. Solso, 87-122. Hillsdale, N.J.: Erlbaum.

227. Shiu, Simon, and Sankar K. Pal. 2004. Foundations of soft casebased reasoning. New Jersey: Wiley.

228. Sinnott-Armstrong, Walter. 2003. Experience and Foundationalism in Audi's The Architecture of Reason. Philosophy and Phenomenological Research 67, no. 1 (July): 181-187.

229. Skyrms, Brian. 1966. Choice and chance: An introduction to inductive logic. Belmont, Calif.: Dickenson Pub. Co.

230. Sloman, Steven A., and Lance J. Rips ed. 1998. Similarity and symbols in human thinking. Amsterdam, the Netherlands: Elsevier Science Publishers, B.V.

231. Sloman, Steven A., Lance J. Rips. 1998. Similarity as an explanatory construct. In Similarity and symbols in human thinking. Edited by S. A. Sloman and L. J. Rips. Amsterdam, the Netherlands: Elsevier Science Publishers, B.V.

232. Souder, Lawrence. 2003. What Are We to Think about Thought Experiments? Argumentation: An International Journal on Reasoning 17, no. 2: 203-217.

233. Sözer, Önay. 2003. The Way to Reason: Philosophy? (in Turkish). Yeditepe'de Felsefe 2 (July): 28-40.

234. Spellman, Barbara A., Keith J. Holyoak. 1996. Pragmatics in Analogical Mapping. Cognitive Psychology 31, no. 307: 346.

235. Spohn, Wolfgang. 1981. Analogy and Inductive Logic: a Note on Niiniluoto. Erkenntnis: An International Journal of Analytic Philosophy 16 (March): 35-52.

236. Stebbing, Susan. 1938. Thinking to some purpose. Lodon: Pelican Books.

237. Steltzer, John. 1983. Analogy and Axiomatics. International Journal of Man-Machine Studies 18, no. 2: 161-173.

238. Stenning, Keith, and Michiel van Lambalgen. 2008. Human reasoning and cognitive science. Cambridge, MA: MIT Press.

239. Suppes, Patrick. 1960. A Comparison of the Meaning and Uses of Models in Mathematics and the Empirical Sciences. Synthese 12: 287-301. 
240. Thagard, Paul. 2000. Coherence in thought and action. Cambridge, MA.: MIT Press.

241. Thagard, Paul. 1988. Dimensions of analogy. In Analogical reasoning: Perspectives of artificial intelligence, cognitive science, and philosophy. Edited by D. H. Helman. Dordrecht: Kluwer Academc Pub.

242. Theron, Stephen. 1997. Argument Forms and Argument from Analogy. Acta Philosophica: Pontificia Universita della Santa Croce 6, no. 2: 303-310.

243. Tindale, Christopher. 2007. Fallacies and argument appraisal. Cambridge: Cambridge University Press.

244. Toulmin, Stephen, Richard D. Rieke, and Allan Janik. 1979. An introduction to reasoning. New York: Macmillan.

245. Turney, Peter D. 2008. The Latent Relation Mapping Engine: Algorithm and Experiments. Journal of Artificial Intelligence Research 33: 615-655.

246. Unknown. 2008. Analogy. Wikipedia, the free encyclopedia : http://en.wikipedia.org/wiki/Analogy.

247. Vadera, Sunil. 1995. Proof by Analogy in Mural. Formal Aspects of Computing 7, no. 2: 183-206.

248. van Dormael, Jan. 1990. The Emergence of Analogy: Analogical Reasoning as a Constraint Satisfaction Process. Philosophica (Belgium) 46, no. 2: 65-76.

249. van Rooij, Iris, Patricia Evans, Moritz Muller, Jason Gedge, and Todd Wareham. 2008. Identifying Sources of Intractability in Cognitive Models: An Illustration Using Analogical Structure Mapping. Proceedings of the 30th Annual Conference of the Cognitive Science Society : 915-920.

250. Volkov, Alexei. 1992. Analogical Reasoning in Ancient China: Some Examples. Extrême Orient-Extrême Occident: Cahiers de Recherches Comparatives 14: 15-48.

251. Vosniadou, Stella, and Andrew Ortony. 1989. Similarity and analogical reasoning. Cambridge; New York: Cambridge University Press.

252. Waller, Bruce. 2001. Classifying Analogies. Informal Logic. 21, no. 3: 199-218.

253. Waller, Bruce N. 2001. Classifying and Analyzing Analogies. Informal Logic 21, no. 3 (Autumn): 199-218.

254. Waller, Bruce N. 1988. Critical thinking: Consider the verdict. Englewood: Cliffs Prentice-Hall.

255. Walton, Douglas. 1996. Argumentation schemes for presumptive reasoning. Mahwah, NJ: Lawrence Erlbaum.

256. Walton, Douglas, Christopher Reed, and Fabrizio Macagno. 2008. Argumentation schemes. Cambridge: Cambridge University Press. 
257. Watson, Ian. 1997. Applying case-based reasoning: Techniques for enterprise systems. San Francisco, CA: Morgan Kaufmann Publishers.

258. Weingartner, Paul. 1979. Analogy Among Systems. Dialectica: International Journal of Philosophy of Knowledge 33, no. 3-4: 355-378.

259. Welch, John R. May 1999. Singular Analogy and Quantitative Inductive Logics. Theoria: Revista de Teoria, Historia y Fundamentos de la Ciencia 14, no. 35: 207-247.

260. Wharton, C. M. 1993. Direct and indirect measures of the roles of thematic and situational knowledge in reminding. Ph.D. diss., Department of Psychology, University of California.

261. Wilcox, James R., Henry L. Ewbank. 1979. Analogy for Rhetors. Philosophy and Rhetoric 12 (Winter): 1-20.

262. Wilson, William H., Graeme S. Halford, Brett Gray, and Steven Phillips. 2001. The STAR-2 model for mapping hierarchically structured analogs. In The analogical mind. Edited by D. Gentner, K. J. Holyoak and B. N. Kokinov. Cambridge, Mass.; London, England: MIT Press/ A Bradford Book.

263. Winston, Patrick H. 1982. Learning New Principles from Precedents and Exercises. Artificial Intelligence 19, no. 3: 321350.

264. Wisdom, John. 1991. Proof and explanation: The virginia lectures. Lanham, Md.: University Press of America.

265. Wisdom, John. 1969. Philosophy and psycho-analysis. Berkeley: University of California Press.

266. Wohlrapp, Harald. 1998. A New Light on Non-Deductive Argumentation Schemes. Argumentation: An International Journal on Reasoning 12, no. 3 (August): 341-350.

267. Wolstencroft, John. 1990. Restructuring, Reminding and Repair: What's Missing from Models of Analogy. AI Communications 2, no. 2: 58-71.

268. Woods, John. 2004. The death of the argument: Fallacies in agent-based reasoning. Dordrecht, The Netherlands: Kluwer Academic Publishers.

269. Woods, John. 2000. Slippery Slopes and Collapsing Taboos. Argumentation: An International Journal on Reasoning 14, no. 2: 107-134.

270. Woods, John. 1999. John Stuart Mill (1806-1873). Argumentation: An International Journal on Reasoning 13, no. 3: 317-334.

271. Woods, John, Brent Hudak. 1989. By Parity of Reasoning. Informal Logic 11: 125-139.

272. Wos, Larry. 1998. The Problem of Reasoning by Analogy. Journal of Automated Reasoning 10, no. 3: 421-422.

273. Wothke, Klaus. 1986. Machine Learning of Morphological Rules by Generalization and Analogy. COLING-86, no. 289: 293. 
274. Wozny, Lucy A. 1989. The Application of Metaphor, Analogy, and Conceptual Models in Computer Systems. Interacting with Computers 1, no. 3: 273-286.

275. Wu, Melissa L., Dedre Gentner. 1998. Structure in categorybased induction. In Proceedings of the twentieth annual conference of the cognitive science society1154-1158.

276. Yan, Jin, Kenneth D. Forbus, and Dedre Gentner. 2003. A theory of representation in analogical matching. In Proceedings of the twenty-fifth annual meeting of the cognitive science society.

277. Yi, Bo, Jiafu Xu. 1993. Analogy Calculus. Theoretical Computer Science 113, no. 2: 211-230.

278. Zuenkov, Michael. 1988. Functioning by Analogy. Fuzzy Sets and Systems 27, no. 3: 261-274.

\section{OTHER}

1. Carignan, Michael. 2003. Analogical Reasoning in Victorian Historical Epistemology. Journal of the History of Ideas 64, no. 33 (July): 445-464.

2. English, Parker. 1992. Affirmative Action and Philosophy Instruction. Teaching Philosophy 15, no. 4 (December): 311-327.

3. Fethe, Charles. 1993. Analogy as a Guide to Philosophical Thinking. Teaching Philosophy 16, no. 1 (March): 59-68.

4. Gross, Daniel M. 2001. Foucault's Analogies, or How to Be a Historian of the Present without Being a Presentist. Clio: A Journal of Literature 31, no. 1: 57-82.

5. Koenigsberger, Dorothy. 1979. Renaissance man and creative thinking: A history of concepts of harmony 1400-1700. Atlantic: Highlands Humanities Press.

6. Lohmar, Dieter. 1998. Intersubjectivity and the meeting of cultures: A critique of the hermeneutics of the 'strict analogy'. In Einheit und vielfalt: Das verstehen der kulturen. Edited by R. A. Mall. Amsterdam: Rodopi.

7. Morgan, Gareth. 1993. Imaginization: The art of creative management. Newbury Park, Calif.: Sage.

8. Pevsner, Nikolaus. 1976. A history of building types. Princeton: Princeton University Press.

9. Rigolot, François. 1998. The Renaissance Crisis of Exemplarity. Journal of the History of Ideas 59, no. 4 (October): 557-563.

10. Spellman, Barbara A., Keith J. Holyoak. 1992. If Saddam is Hitler then who is George Bush? Analogical Mapping Between Systems of Social Roles. Journal of Personality and Social Psychology 62, no. 6: 913-933. 
198 Marcello Guarini et al.

11. Tambiah, Stanley J. 1973. Form and meaning of magical acts: A point of view. In Modes of thought. Edited by R. Horton and R. Finnegan. London: Faber and Faber.

12. Thagard, Paul, Craig Beam. 2004. Epistemological Metaphors and the Nature of Philosophy. Metaphilosophy 3, pt. 5, no. 4 (July): 504-516.

13. Thompson, Leigh, Dedre Gentner, and Jeffrey Loewenstein. 2000. Avoiding Missed Opportunities in Managerial Life: Analogical Training More Powerful than Individual Case Training. Organization Behaviour and Human Decision Processes 82, no. 1: 60-75. 